\title{
Data Quality Objectives Summary Report Supporting Radiological Air Surveillance Monitoring for the INL Site
}

May 2015

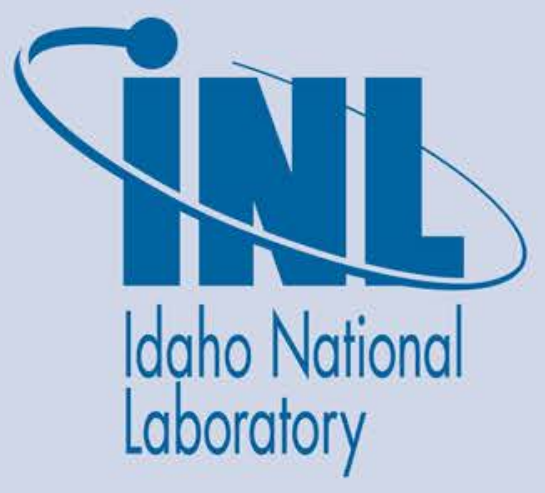

The INL is a U.S. Department of Energy National Laboratory operated by Battelle Energy Alliance 


\section{DISCLAIMER}

This information was prepared as an account of work sponsored by an agency of the U.S. Government. Neither the U.S. Government nor any agency thereof, nor any of their employees, makes any warranty, expressed or implied, or assumes any legal liability or responsibility for the accuracy, completeness, or usefulness, of any information, apparatus, product, or process disclosed, or represents that its use would not infringe privately owned rights. References herein to any specific commercial product, process, or service by trade name, trade mark, manufacturer, or otherwise, does not necessarily constitute or imply its endorsement, recommendation, or favoring by the U.S. Government or any agency thereof. The views and opinions of authors expressed herein do not necessarily state or reflect those of the U.S. Government or any agency thereof. 


\title{
Data Quality Objectives Summary Report Supporting Radiological Air Surveillance Monitoring for the INL Site
}

May 2015

\author{
Idaho National Laboratory \\ Idaho Falls, Idaho 83415
}

http://www.inl.gov

Prepared for the U.S. Department of Energy Office of Nuclear Energy Under DOE Idaho Operations Office

Contract DE-AC07-05ID14517 



\section{SUMMARY}

This report documents the data quality objectives (DQOs) developed for the Idaho National Laboratory (INL) Site's ambient air surveillance program. Development of the DQOs was based on the seven-step process recommended "for systematic planning to generate performance and acceptance criteria for collecting environmental data." ${ }^{\text {a }}$ The process helped determine the type, quantity, and quality of data needed to meet current regulatory requirements and to follow U.S. Department of Energy guidance for environmental surveillance air monitoring design. It also considered the current air monitoring program that has existed at the INL Site since the 1950s.

Development of the DQOs involved application of the atmospheric dispersion model CALPUFF to identify likely contamination dispersion patterns at and around the INL Site using site-specific meteorological data. Model simulations were used to quantitatively assess the probable frequency of detecting airborne radionuclides released by INL Site facilities using existing and proposed air monitors.

a EPA, 2006, “Guidance on Systematic Planning Using the Data Quality Objectives Process,” EPA/240/B-06/001, U.S. Environmental Protection Agency, February 2006. 


\section{CONTENTS}

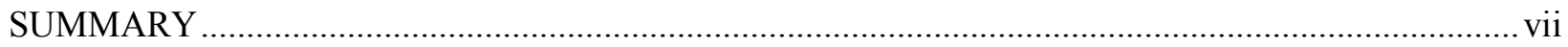

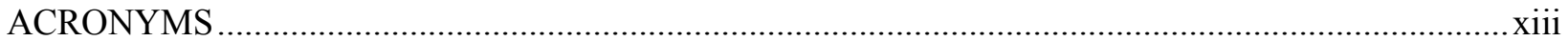

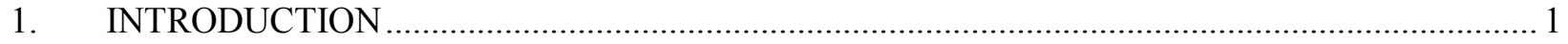

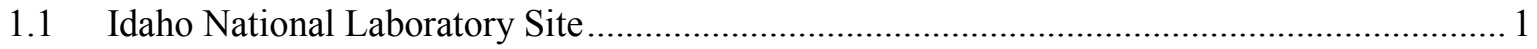

2. DATA QUALITY OBJECTIVE STEP 1 -STATE THE PROBLEM ........................................ 6

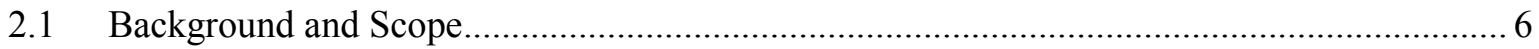

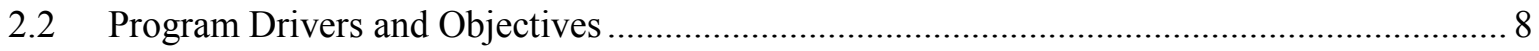

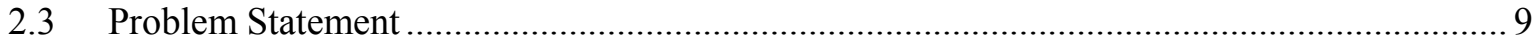

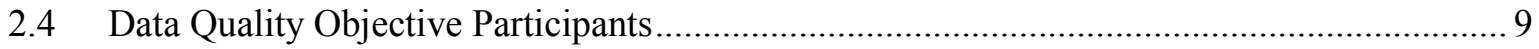

3. DATA QUALITY OBJECTIVE STEP 2-IDENTIFY THE GOALS OF THE STUDY .............. 10

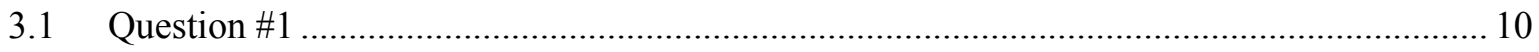

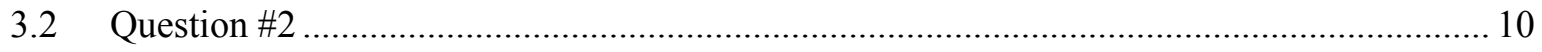

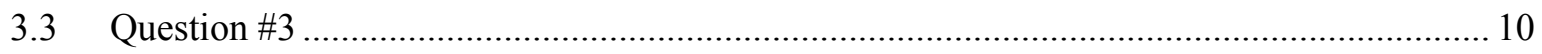

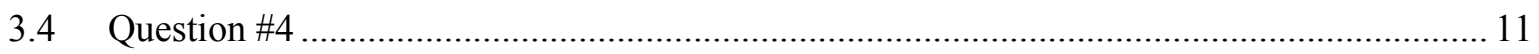

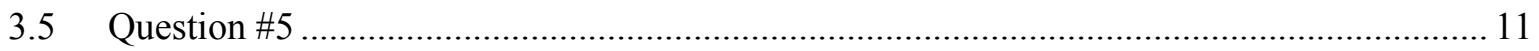

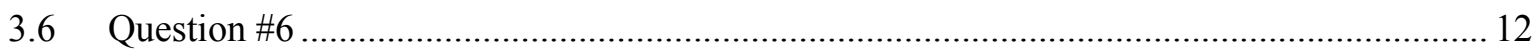

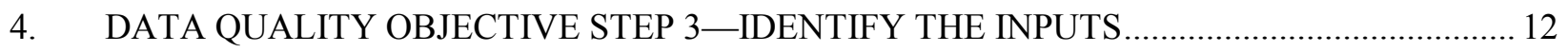

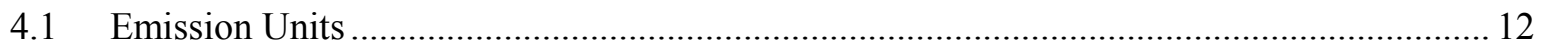

4.2 Radionuclides of Concern and Release Quantities ........................................................... 13

4.3 Air Dispersion Modeling and Frequency of Detection Methodology................................... 13

4.4 Receptor Locations and Exposure Characteristics ......................................................... 21

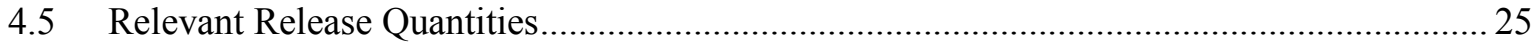

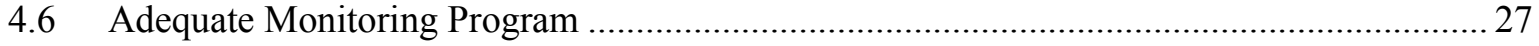

4.7 Existing Idaho National Laboratory Ambient Air Monitoring Network …......................... 27

5. DATA QUALITY OBJECTIVE STEP 4—DEFINE THE BOUNDARIES …...........................28 


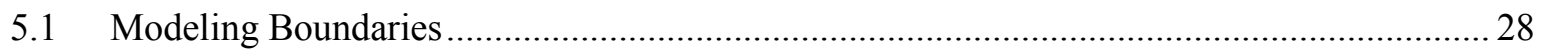

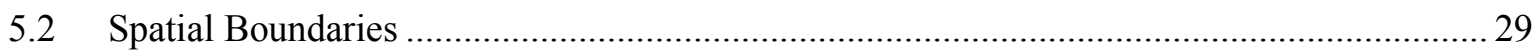

5.3 Temporal Boundaries and Resolution .......................................................................... 29

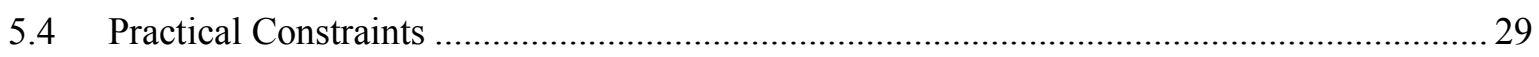

6. DATA QUALITY OBJECTIVE STEP 5-DEVELOP DECISION RULES ..............................29

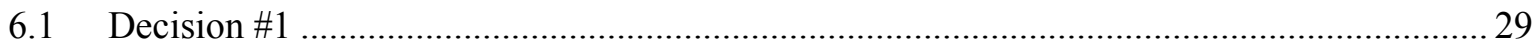

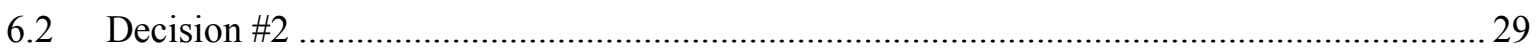

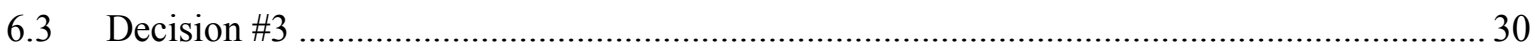

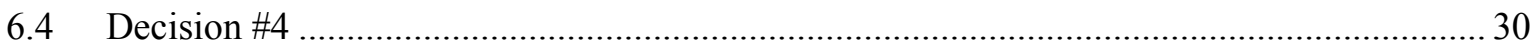

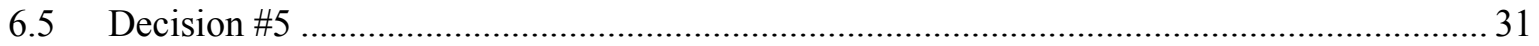

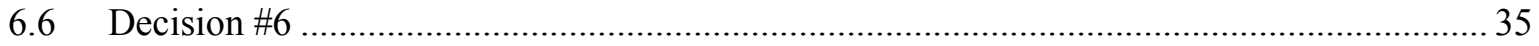

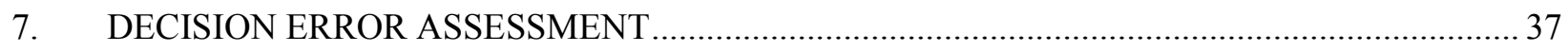

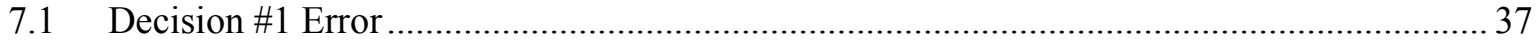

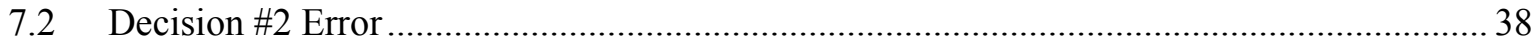

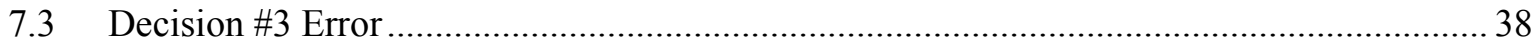

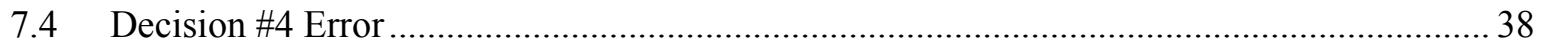

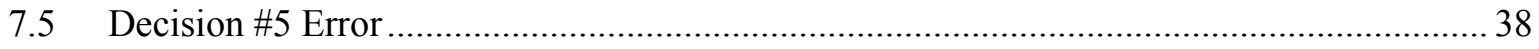

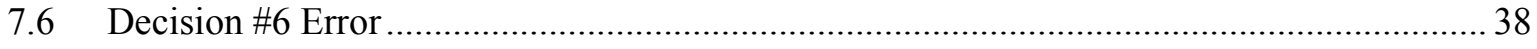

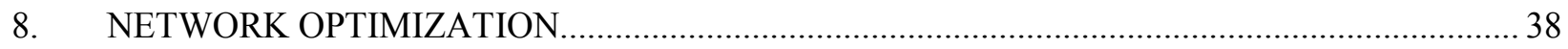

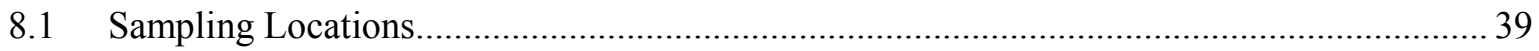

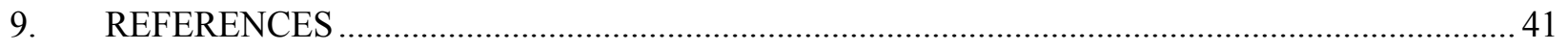

FIGURES

1. Location of the INL Site in southeastern Idaho ................................................................. 2

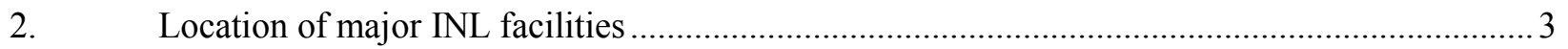

3. Census divisions located within 50 miles $(80 \mathrm{~km})$ of INL Site facilities (inside dashed line)..... 4 


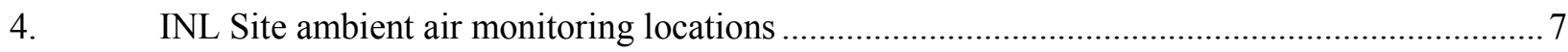

5. 98 potential resident receptor locations identified by ESER (i.e., black dots) and the 27 potential resident receptor locations used in the model

6. Atmospheric dispersion modeling domain showing all INL air monitoring locations.

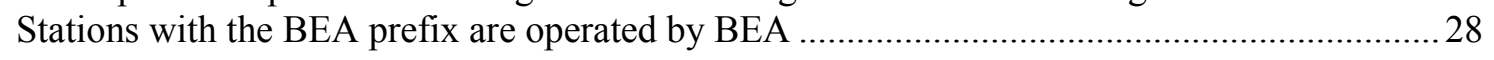

7. FD of a hypothetical network containing 16-samplers encircling the facility ........................ 35

8. Contour plot of the annual average dispersion factor (or $\mathrm{X} / \mathrm{Q}$ in $\mathrm{s} / \mathrm{m}^{3}$ ) for a steady-state release from MFC-764 stack

9. FD versus azimuth for Am-241 released from the MFC-764 stack over a 24-hour period

A-1. Diagram showing downwind distance and crosswind distance for a receptor located at azimuth 45 degrees and wind vector azimuth of 58 degrees..... 48

\section{TABLES}

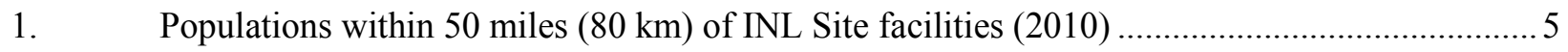

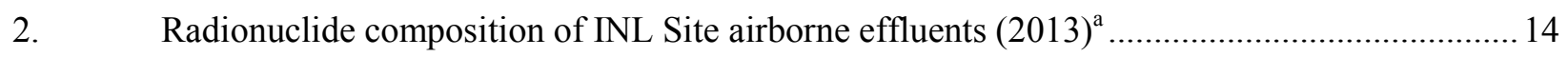

3. Radionuclides important in terms of radiological dose based on the 2007 to 2013 NESHAP reports

4. Universal Transverse Mercator coordinates of the 27 potential resident receptor locations used in the model.

5. Distance from each INL facility to the nearest grazing allotment boundary

6. Unit doses, APDCs, and inhalation dose coefficients from DOE-STD-1196-2011

(2011) for the important radionuclides at the INL Site

7. Release quantities (pCi) that would result in a maximum weekly dose of $0.0192 \mathrm{mrem}$ (equivalent to $1 \mathrm{mrem} /$ year if continuous over a year)

8. Release quantities (pCi) that would result in a maximum 24-hour dose of 1.0 mrem at the nearest distance to a grazing allotment from an INL Site facility

9. Description of modeled sources and locations that were considered in the assessment.....

10. Stack release parameters

11. Location of reference resident for a 168-hour release (1-week) that results in 0.0192 mrem (1.0 mrem/year). 
12. Azimuth and distance location of the reference resident location for a 24-hour release (1-day) that results in $1 \mathrm{mrem}$

13. Radionuclide MDA, TIC values that yield dose limits, and activity accumulated on filters for the given TIC

14. Objective A network FD and intensity for a hypothetical sampling network consisting of samplers at each of the 27 resident locations

15. Objective B network FD and intensity for the 16 hypothetical samplers surrounding the facility at a distance equal to the nearest grazing allotment boundary

16. Network FD and intensity for Objective A and the existing sampling network consisting of 36 samplers located on and off the INL Site 36

17. Network FD and intensity for Objective B and the existing INL Site sampling network ..........37

18. Network FD and intensity for Objective B and the optimized INL Site sampling network

19. Percent change in network FD and intensity from the optimized and existing network

A-1. Am-241 inhalation dose and TIC for a release of 6.907E+07 pCi from CPP-1774, 1hour release time.

B-1. Tritium sampler data from Atomic City for sampling during 2014 


\section{ACRONYMS}

APDC all-pathway dose coefficient

ASER

Annual Site Environmental Report

ATR

Advanced Test Reactor

BEA

Battelle Energy Alliance, LLC

CFA Central Facilities Area

CITRC Critical Infrastructure Test Range Complex

DOE U.S. Department of Energy

DOE-ID U.S. Department of Energy Idaho Operations Office

DQO data quality objective

EPA Environmental Protection Agency

ESER Environmental Surveillance, Education, and Research (Program)

FD frequency of detection

INL Idaho National Laboratory

INTEC Idaho Nuclear Technology and Engineering Center

MDA minimum detectable activity

MEI maximally exposed individual

MFC Material and Fuels Complex

NESHAP National Emission Standards for Hazardous Air Pollutants

NRF Naval Reactors Facility

PSQ principal study question

RWMC Radioactive Waste Management Complex

SMC Specific Manufacturing Capability

TAN Test Area North

TIC time-integrated concentration

$\mathrm{TICu}$ time-integrated concentration for a unit $(1 \mathrm{Ci})$ release 


\title{
Data Quality Objectives Summary Report Supporting Radiological Air Surveillance Monitoring for the INL Site
}

\author{
1. INTRODUCTION
}

This data quality objective (DQO) summary report supports decision-making activities for the Idaho National Laboratory (INL) radionuclide air surveillance monitoring program. This document specifically addresses air surveillance monitoring activities and does not address facility emissions monitoring. Facility emissions that have the potential to exceed National Emission Standards for Hazardous Air Pollutants (NESHAP) limits are either monitored at the source or calculated to show compliance with U.S. Department of Energy (DOE) requirements, federal and state laws and regulations, and industry standards.

The organization of this report is based on the U.S. Environmental Protection Agency's (EPA's) guidance for developing DQOs (EPA 2006). Major steps involved in the process are described in Sections 2 through 7; however, some information from Section 1.1 is relevant to establishing the problem statement in Section 2. Information from key documents such as annual site environmental reports (ASERs), the Technical Basis for Environmental Monitoring and Surveillance at the INL Site (DOE-ID 2014a), and Development and Demonstration of a Methodology to Quantitatively Assess the INL Site Ambient Air Monitoring Network (Rood and Sondrup 2014) is summarized and/or referenced where appropriate.

\subsection{Idaho National Laboratory Site}

The INL Site is a DOE reservation located in southeastern Idaho approximately 25 miles west of Idaho Falls (Figure 1). At 890 square miles (569,135 acres), the INL Site is slightly smaller than the state of Rhode Island. Federal lands surround much of the INL Site, including Bureau of Land Management lands and Craters of the Moon National Monument to the southwest, Challis National Forest to the west, and Targhee National Forest to the north (Figure 2). Mud Lake Wildlife Management Area, Camas National Wildlife Refuge, and Market Lake Wildlife Management Area are within $80 \mathrm{~km}$ (50 miles) of the INL Site. About $60 \%$ of the INL Site is open to livestock grazing and hunting is permitted in a limited area on the northwest and northeast portions of the site.

INL was established in 1949 as the National Reactor Testing Station. The original mission of INL was to build, test, and operate various nuclear reactors and associated facilities. The isolated location ensured maximum public safety in the field of nuclear research. Today, INL is a multi-program laboratory that supports DOE missions and business lines of nuclear energy research, energy resources, science and technology, and national security. INL has no permanent residents and ingress and egress of INL Site personnel and visiting personnel are strictly controlled. No casual visits are permitted, except for persons driving through INL on one of five public highways and visitors to the Experimental Breeder Reactor I, a national historic monument, which is open during the summer months. Security forces may interrupt traffic on INL roads or public roads that transverse INL during emergencies and other times to support operations of the laboratory.

The INL Site consists of several primary facilities situated on an expanse of otherwise undeveloped terrain. Buildings and structures at the INL Site are clustered within these facilities, which are typically less than a few square miles in size and separated from each other by miles of undeveloped land. The major facilities at the INL Site are the Advanced Test Reactor (ATR) Complex; Central Facilities Area (CFA); Critical Infrastructure Test Range Complex (CITRC); Idaho Nuclear Technology and Engineering Center (INTEC); Materials and Fuels Complex (MFC); Naval Reactors Facility (NRF); Radioactive Waste Management Complex (RWMC); and Test Area North (TAN), which includes the Specific 
Manufacturing Capability (SMC) (Figure 2). The INL Site boundary establishes the effective exclusion boundary defined in 10 CFR 100 for protection from exposure to airborne radioactivity. DOE controls all activities within the exclusion area.

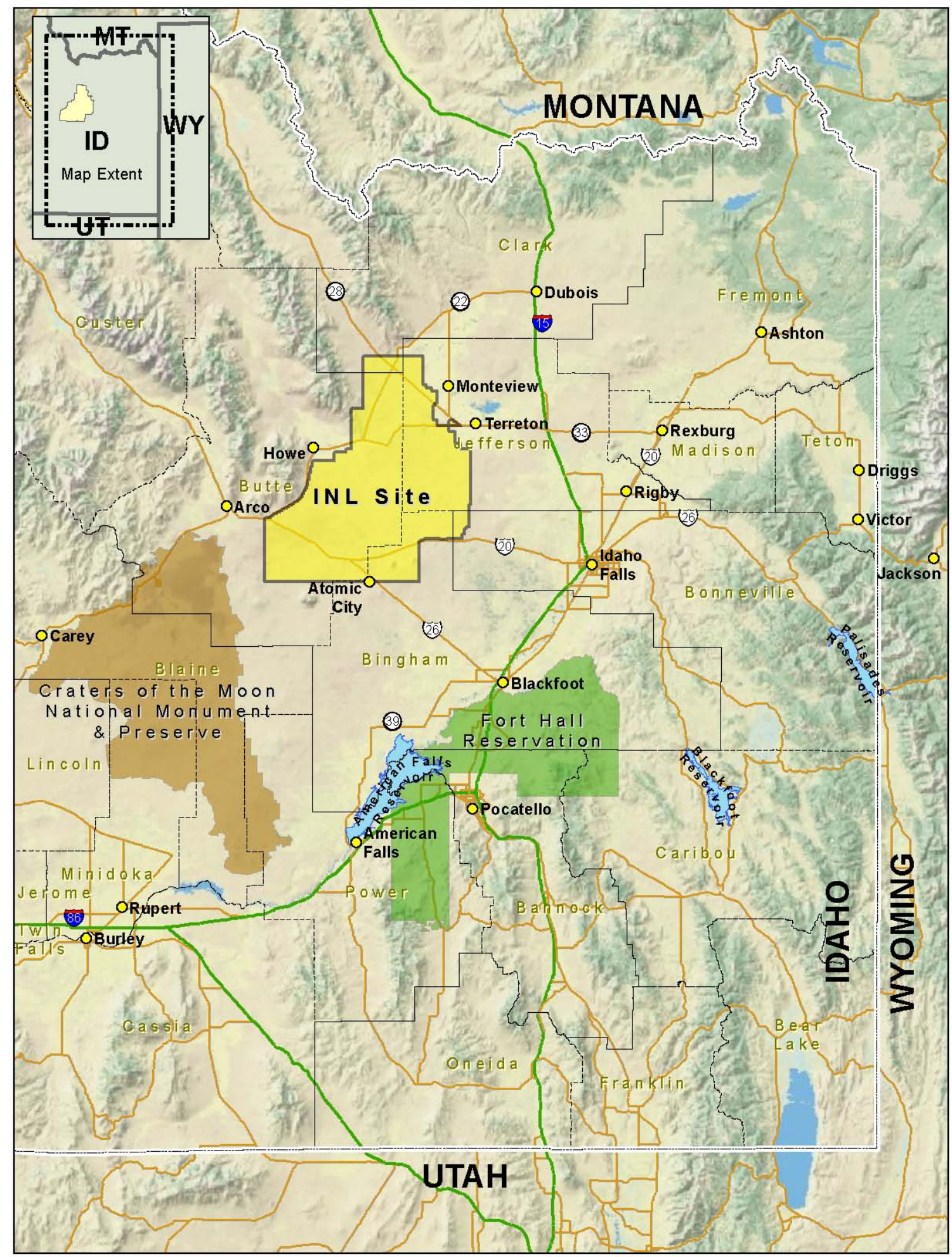

Figure 1. Location of the INL Site in southeastern Idaho. 


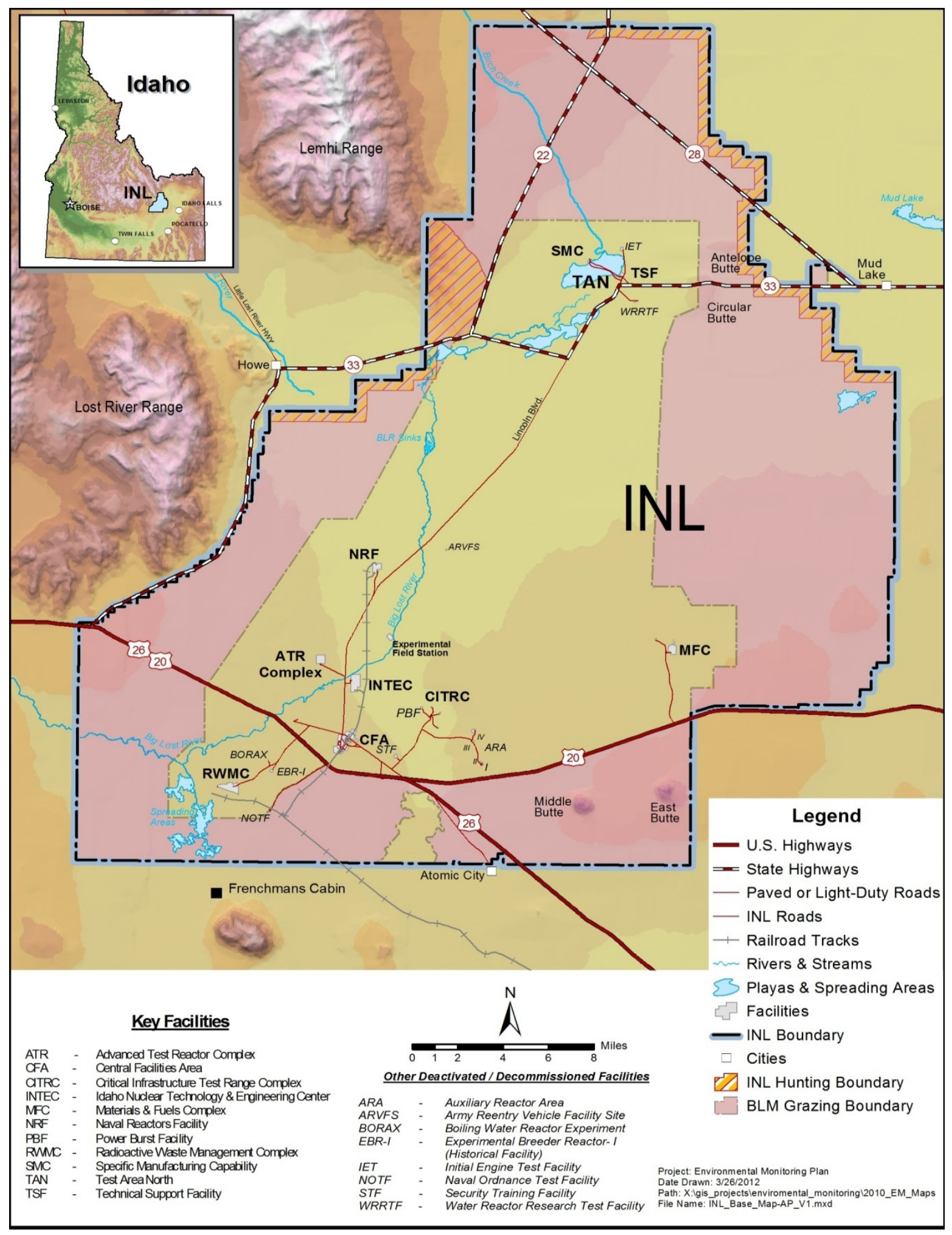

Figure 2. Location of major INL facilities.

Major communities near the INL Site include Blackfoot in Bingham County, Idaho Falls in Bonneville County, Arco in Butte County, and Rigby in Jefferson County. Census divisions located 
within 50 miles $(80 \mathrm{~km})$ of INL Site facilities are shown in Figure 3. Populations within these divisions and selected population centers in these counties are shown in Table 1 (U.S. Census Bureau 2010). The community nearest the INL Site is Atomic City, located south of the Site's border on

U.S. Highway 20/26. Other population centers near the INL Site include Howe, west of the INL Site on U.S. Highway 22/33, and Mud Lake and Terreton (within the Hammer census division) on the northeast border of the INL Site.

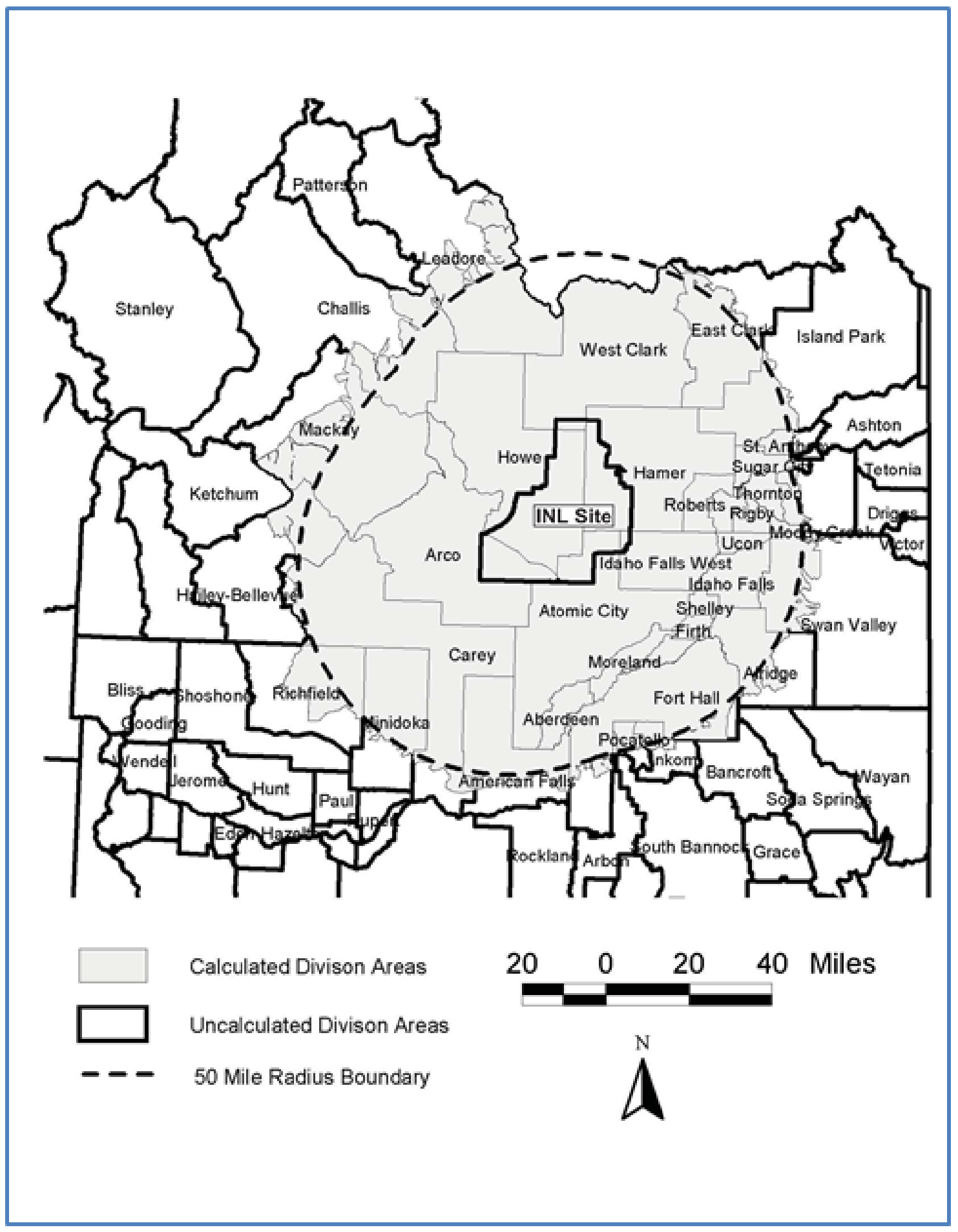

Figure 3. Census divisions located within 50 miles $(80 \mathrm{~km})$ of INL Site facilities (inside dashed line). 
Table 1. Populations within 50 miles $(80 \mathrm{~km})$ of INL Site facilities (2010).

\begin{tabular}{|c|c|}
\hline Census Division ${ }^{\mathrm{a}, \mathrm{b}}$ & Population $^{\mathrm{c}}$ \\
\hline Aberdeen & 3,235 \\
\hline Alridge & 573 \\
\hline American Falls & 6,166 \\
\hline Arbon (part) & 29 \\
\hline Arco & 2,533 \\
\hline Atomic City (division) & 2,679 \\
\hline Blackfoot & 14,694 \\
\hline Carey (part) & 1,001 \\
\hline East Clark & 78 \\
\hline Firth & 3,329 \\
\hline Fort Hall (part) & 4,284 \\
\hline Hailey-Bellevue (part) & 5 \\
\hline Hamer & 2,338 \\
\hline Howe & 358 \\
\hline Idaho Falls & 95,095 \\
\hline Idaho Falls, west & 1,738 \\
\hline Inkom (part) & 614 \\
\hline Island Park (part) & 90 \\
\hline Leadore (part) & 6 \\
\hline Lewisville-Menan & 4,096 \\
\hline Mackay (part) & 1,207 \\
\hline Moody (part) & 5,921 \\
\hline Moreland & 10,134 \\
\hline Pocatello & 71,722 \\
\hline Rexburg & 25,058 \\
\hline Rigby & 16,274 \\
\hline Ririe & 1,781 \\
\hline Roberts & 1,651 \\
\hline Shelley & 8,203 \\
\hline South Bannock (part) & 312 \\
\hline St. Anthony (part) & 2,469 \\
\hline Sugar City & 6,416 \\
\hline Swan Valley (part) & 5,976 \\
\hline Ucon & 6,125 \\
\hline West Clark & 904 \\
\hline Total & $\mathbf{3 0 7 , 0 7 4}$ \\
\hline
\end{tabular}

\footnotetext{
a. The U.S. Census Bureau divides the country into four census regions and nine census divisions. The bureau also divides counties (or county equivalents) into census county divisions.

b. (Part) means only a part of the county census division lies within the 50 -mile (80-km) radius of a major INL Site facility.

c. Population from 2010 Census Report for Idaho.
} 


\section{DATA QUALITY OBJECTIVE STEP 1-STATE THE PROBLEM}

The objective of DQO Step 1 is to use relevant information to state the problem to be resolved. This chapter describes background information, program drivers, and objectives (see Sections 2.1 and 2.2) used to establish the problem statement (see Section 2.3), and identifies the participants responsible for developing the DQOs (Section 2.4).

\subsection{Background and Scope}

A complete description of the INL ambient air surveillance monitoring program and pertinent background information and data are contained in the Technical Basis for Environmental Monitoring and Surveillance at the INL Site (DOE-ID 2014a). Some information from the DOE Idaho Operations Office (DOE-ID) (2014a) relevant to establishing DQOs is summarized in Sections 2.1 and 2.2 for convenience.

At the INL Site, radionuclide releases to the environment are managed using the As Low As Reasonably Achievable concept. This approach to radiation protection involves managing and controlling releases of radioactive material to the environment and exposure to the work force and to members of the public so that the levels are as far below the applicable limits as reasonably achievable. With respect to releases that do occur, DOE requires the INL Site to show that human health and the environment are protected, which is accomplished through direct effluent sampling at the point of exhaust and/or ambient air surveillance at locations both on and off the Site. The focus of this document is on the ambient air surveillance program.

Air monitoring conducted on and around the INL Site for environmental surveillance purposes is collectively termed "ambient air monitoring." Ambient air surveillance is not emissions monitoring. Rather, the ambient air monitoring program complements emissions monitoring and modeling by confirming that modeling is reliable, emissions control and measurement equipment are functioning, and diffuse and unmonitored emissions are not causing unacceptable radiation doses to members of the public and to populations of biota. The goal of the ambient air monitoring program is to determine the status of the INL Site's compliance with applicable public health and environmental quality standards and with program objectives outlined in Section 2.2.

To accomplish their objectives, the INL Site ambient air monitoring program operates a network of low-volume air samplers (Figure 4) that monitor atmospheric levels of radioactive particulates and radioiodine released from INL Site facilities, natural radioactivity (e.g., radon and daughters), and fallout from worldwide nuclear detonations or nuclear accidents. Samples are analyzed to determine whether radiation doses to the public are within the limits established in DOE Order 458.1 (2011), to evaluate background and site contributions of radioactive material to the environment, and to provide documentation of ambient air concentrations in the event of a non-routine or unplanned release. The number and location of samplers that make up the ambient air monitoring network has evolved considerably since routine air monitoring began in the 1950s. Air samplers have typically been placed at facilities with significant radiological sources, at offsite locations likely to be most impacted by emissions, background locations, and at locations chosen to help characterize ground-level concentrations between the source and populated areas. Currently, samplers are located near each major onsite facility, at locations in the predominant wind directions several miles from the facilities, and in several distant locations, including the towns of Idaho Falls, Rexburg, and Blackfoot, Idaho; Jackson, Wyoming; and Craters of the Moon National Monument west of Arco, Idaho.

The current sampling network and sampling protocols were determined before the first guidance document (DOE 1991) was created and before the existence of the DQO process. For example, sampler locations were based on evaluations of facility releases, population centers, prevailing wind directions, accessibility, and power availability. Samples have been collected weekly from these monitors for decades. 


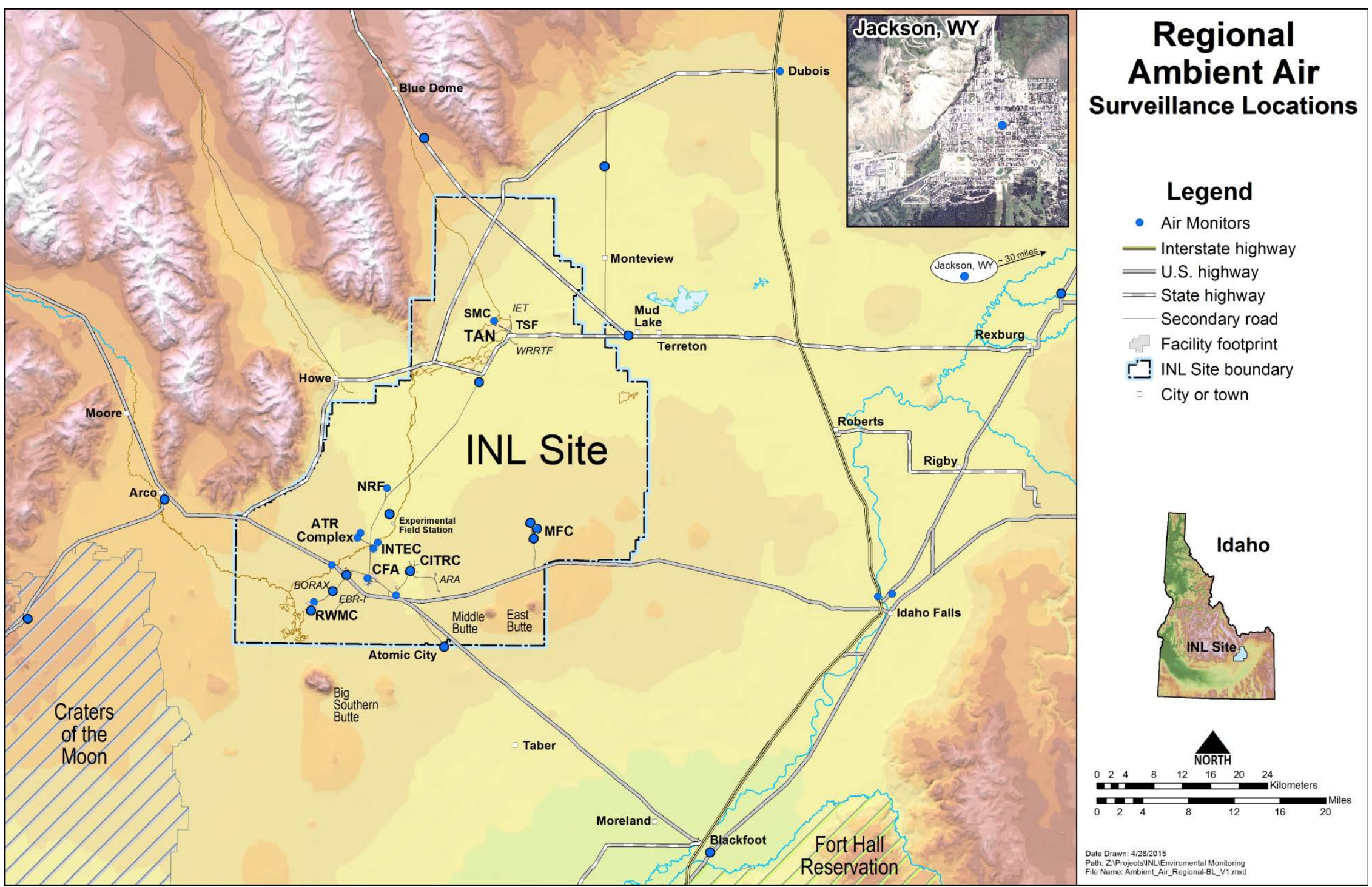

Figure 4. INL Site ambient air monitoring locations. 
Although the current network conforms to the most recent guidance (DOE 2015) and includes sampling stations beyond the minimum number required, the objective of this exercise is to use the DQO process to determine the environmental monitoring needs for routine radiological air emissions to the atmosphere from the INL Site in response to applicable requirements.

\subsection{Program Drivers and Objectives}

Ambient air monitoring is performed on and around the INL Site to meet the following requirements and criteria for environmental surveillance of DOE facilities:

- DOE Order 458.1, "Radiation Protection of the Public and the Environment"

- DOE Handbook, "Environmental Radiological Effluent Monitoring and Environmental Surveillance," DOE-HDBK-1216-2015 (DOE 2015)

- 40 CFR 61, Subpart H, "National Emission Standards for Emissions of Radionuclides Other than Radon from Department of Energy Facilities."

To determine compliance with the NESHAP Subpart H standard, "radionuclide emissions are monitored or determined and effective dose equivalent values to members of the public are calculated using EPA approved sampling procedures, computer models CAP-88 or AIRDOS-PC and other procedures for which EPA has granted prior approval." The INL Site complies with NESHAP requirements through direct monitoring and dose calculations using CAP-88PC. Because of this, the INL Site ambient air surveillance program is not intended to show direct compliance with the NESHAP regulation. The program is primarily established based on DOE guidance and merely complements NESHAP emissions monitoring and modeling by confirming that emissions control and measurement equipment are functioning and diffuse and unmonitored emissions are not causing unacceptable doses offsite (i.e., greater than 10 mrem to the maximally exposed individual [MEI]).

Other key drivers of the ambient air surveillance program include input from local residents, including Native American tribes and other stakeholders.

Because radiological releases from INL Site operations and scientific activities could impact human health and the environment, DOE Order 458.1 (2011) states the following:

Environmental monitoring must be conducted to characterize routine and non-routine releases of radioactive material from radiological activities, estimate the dispersal pattern in the environs, characterize the pathway(s) of exposure to members of the public and estimate the doses to individuals and populations in the vicinity of the site or operation commensurate with the nature of the DOE radiological activities and the risk to the public and the environment.

The DOE Handbook (DOE 2015) was developed to assist in the establishment and maintenance of effective environmental monitoring activities, which includes effluent monitoring, environmental surveillance, meteorological monitoring, and pre-operational monitoring. In the case of environmental surveillance, which the DQOs documented in this report address, the DOE Handbook assists in characterization of the environs around DOE activities and supports assessment of potential public exposure through available pathways (e.g., air, water, soil, and biota).

The minimum criteria for determining the need for environmental surveillance is provided in Table 6-1 of the DOE Handbook (DOE 2015). According to these criteria, measurements or provisions for detection should be made for the following:

- Unplanned releases of radionuclides to the environment

- Characterization of background 
- Pathway measurements (actual measurements on two media for each critical radionuclide/pathway combination)

- Routine surveillance of all pathways (i.e., ingestion, inhalation, and immersion doses) -or-

- Periodic confirmation of potential doses.

The criteria state that routine surveillance of all pathways should be conducted if the annual dose at the site of the hypothetical MEI might exceed 5-mrem effective dose or 100 person-rem collective effective dose with a radius of $80 \mathrm{~km}$. Periodic measurements are recommended at $20 \%$ of the reference dose (e.g., 1 mrem per year) or if biota screening levels are challenged.

Recent dose calculations for the INL Site result in a dose to the MEI less than $0.1 \mathrm{mrem} / \mathrm{year}$ and less than 0.5 person-rem for the 50-mile population (DOE-ID 2014b). Moreover, biota screening levels have not been exceeded in recent calculations (DOE-ID 2014b). However, in the interest of As Low As Reasonably Achievable and to ensure detection of INL Site releases well before dose standards are approached, the INL Site's objective is to determine whether the air surveillance network meets the requirements of being able to detect radioactive air emissions resulting in a dose to the MEI of greater than or equal to $1.0 \mathrm{mrem} / \mathrm{year}$. This ensures protection of the public and the environment.

Specific program objectives for the ambient air surveillance network that are derived from these goals and other drivers include the following:

- Measure background concentrations of radionuclides in air

- Measure concentrations of radionuclides in air at locations that could be impacted by routine INL Site operations

- Determine INL Site contributions of airborne radionuclides to the environment

- Detect and report trends in measured concentrations of airborne radionuclides

- Compare measured concentrations to reference regulatory levels (in this case, derived concentration standards presented in Derived Concentration Technical Standard, DOE-STD-1196-2011, April 2011)

- Provide surveillance results that can be used in dose calculations for reporting to the public.

Neither the ambient air surveillance program nor the methods approved by regulations for estimating atmospheric dispersion and dose consequences were intended to be applied to high-level or acute (i.e., short-term) emissions from accidents involving radioactive materials or to facility effluent monitoring. Therefore, the discussions and conclusions in this document are applicable to routine and fugitive emissions from facilities that may be characterized as chronic emissions (or occurring at substantially the same rate over time) or to short-term emissions.

\subsection{Problem Statement}

The objective of this report is to determine the ambient air surveillance needs for routine radiological air emissions to the atmosphere from the INL Site that meet regulatory requirements and objectives presented in Section 2.2 of this report.

\subsection{Data Quality Objective Participants}

Participants were selected to participate in the seven-step DQO development process based on their technical background and expertise. Participants included representatives from Battelle Energy Alliance, LLC (BEA) and Gonzales-Stoller Surveillance and their subcontractors and include the following: 
- Scott Lee, Manager, Regulatory and Monitoring Services, BEA

- Tom Haney, BEA

- Dave Frederick, BEA

- Swen Magnuson, BEA

- Jeff Sondrup, BEA

- Arthur Rood, K-Spar Inc.

- Marilyn Case, Gonzales-Stoller Surveillance

- Doug Halford, Gonzales-Stoller Surveillance.

\section{DATA QUALITY OBJECTIVE STEP 2-IDENTIFY THE GOALS OF THE STUDY}

Step 2 of the DQO process involves identifying the principal study questions (PSQs) that must be resolved to address the problem identified in Step 1 and the alternative actions that would result from resolution of the PSQs.

Information required to resolve the PSQs includes data and bounding conditions to identify, as necessary, monitoring locations, equipment, and protocols to demonstrate adequate assessment of INL Site radiological air emissions at onsite and offsite locations.

\subsection{Question \#1}

\section{What radionuclides-of-concern are expected in the air effluent stream on the INL Site?}

State the basis for determining the radionuclides expected to be found.

List the method used to determine the radionuclides of concern.

List the primary radionuclides of concern and their form (e.g., particulate, vapor, or gas).

Action \#1: Use available isotope information from the most recent NESHAPS report to establish a list of radionuclides of concern and their particular form.

\subsection{Question \#2}

What are the potential emission sources for radiological air emissions on the INL Site and which are most critical for addressing the study question?

A. Identify major emission sources and their release characteristics needed for air dispersion modeling

(i.e., location, discharge point height and diameter, exit velocity, and temperature).

Identify minor emission sources, including diffuse/fugitive sites.

Action \#2: Determine which INL Site emission sources generate the greatest offsite impacts, based on qualitative or, if needed, quantitative criteria.

\subsection{Question \#3}

What radionuclide release rates are routinely expected from the INL Site emission unit(s) of interest?

A. Determine the emission rates of the radionuclides of concern from routine operations. 
B. What release quantities would result in a dose limit being approached at an MEI?

Action \#3: Determine radionuclide release rates that are routinely expected from INL Site facilities and release quantities that would result in dose limits being approached at an MEI.

\subsection{Question \#4}

\section{Where do models predict the location of maximum impact for potential receptors for each INL Site emission source of interest (see Question \#2)?}

A. Determine the locations of potential onsite and offsite receptors and appropriate exposure scenarios for each.

Use an appropriate atmospheric dispersion model to determine impacts at potential receptor locations for given exposure scenarios and identify the location of highest projected dose for each INL Site source.

Action \#4: Apply an appropriate atmospheric dispersion model to determine the receptor locations with maximum impact.

\subsection{Question \#5}

What are the requirements for an adequate radioactive air monitoring program? What are the performance metrics of an adequate air monitoring network? What are the parameters (e.g., number of and placement of monitors, etc.) of an adequate sampling network?

A. The requirements for an air monitoring program for radionuclides are documented in the DOE Handbook (DOE 2015). This guidance document establishes the analytical and quality assurance requirements that are applied to air monitoring networks.

DOE Order 458.1 (2011) states radiological activities must be conducted so that exposure of members of the public to ionizing radiation will

not cause a total effective dose (TED) exceeding $100 \mathrm{mrem}(1 \mathrm{mSv})$ in a year, an equivalent dose to the lens of the eye exceeding 1,500 mrem $(15 \mathrm{mSv})$ in a year, or an equivalent dose to the skin or extremities exceeding $5000 \mathrm{mrem}(50 \mathrm{mSv})$ in a year, from all sources of ionizing radiation and exposure pathways that could contribute significantly to the total dose. This does not include doses from radon and its decay products in air, doses received by patients from medical sources of radiation, dose from background radiation, and dose from occupational exposure.

40 CFR Part 61, Subpart H states that emissions of radionuclides to ambient air from DOE facilities shall not exceed those amounts that would cause any member of the public to receive in any year an effective dose equivalent exceeding $10 \mathrm{mrem} /$ year.

Action \#5: Develop an air monitoring program that considers applicable regulatory requirements, equipment/sampling specifications, and optimal locations. Establish performance metrics for the network and quantitatively evaluate network performance using a site-applied atmospheric transport model coupled with frequency of detection (FD) methods. 


\subsection{Question \#6}

\section{Does the existing air monitoring program/network meet the requirements established by resolution of PSQ\#5?}

A. Assess the adequacy of the current INL and Environmental Surveillance, Education, and Research (ESER) Program air surveillance networks (i.e., numbers, location, analytes, collection frequency, detection limits, etc.) using a site-applied atmospheric transport model coupled with FD methods.

Identify potential deficiencies in the monitoring network and recommend improvements.

Action \#6: Use an atmospheric transport model coupled with FD methods to evaluate whether the existing INL Site monitoring network meets the stated performance objectives.

\section{DATA QUALITY OBJECTIVE STEP 3-IDENTIFY THE INPUTS}

This chapter lists and describes the data, methods, and assumptions used to resolve the decision statements identified in Step 2. Additionally, the DOE Handbook, (DOE 2015) provides guidance for meeting the requirements of DOE Order 458.1. It also includes guidance for airborne effluent monitoring and environmental surveillance. Although its structured content is not explicitly followed in this DQO report, participants referred to its content throughout the DQO process to ensure critical items were not omitted or overlooked.

Sections 4.1and 4.2 identify emission sources, radionuclides of concern, and potential release rates for resolving PSQs 1 through 3. Section 4.3 describes a methodology that can be used to objectively assess an air monitoring network design against established performance objectives for addressing PSQ 4 . The methodology uses atmospheric transport models to evaluate design and sampling protocols for the network or portions of the network. Section 4.4 identifies the potential receptors and exposure characteristics necessary to resolve PSQ 4. Section 4.5 identifies relevant release quantities that are used to determine the locations of maximum impact from potential receptor locations discussed in Section 4.4. Section 4.6 identifies relevant regulatory requirements monitoring programs for resolution of PSQ 5. Section 4.7 contains details of the existing INL ambient air monitoring network that can be used with the information in Sections 4.4through 4.6 to assess the INL network to resolve PSQ 6.

\subsection{Emission Units}

Eight major facilities at the INL Site have potential to emit radionuclides into the environment. These include the ATR Complex, CFA, CITRC, INTEC, MFC, NRF, RWMC, and TAN (which includes SMC) (see Figure 2). Although NRF is owned by the Naval Reactors Idaho Branch Office and the Naval Nuclear Propulsion Program is exempt from DOE requirements and maintains a separate environmental monitoring program, NRF emissions are considered in the air monitoring system evaluation and are included here for completeness.

Airborne contaminants are monitored because air is the primary exposure pathway to humans from contaminant releases at the INL Site (DOE-ID 2014a). Airborne effluent can be released from individual point sources (such as laboratory ventilation systems or stacks) or diffuse sources (such as re-suspension of contaminated soil). Some INL Site sources require continuous monitoring for compliance (e.g., continuous stack monitors). Every year, an estimate of the annual radionuclide emissions at the INL Site is prepared in accordance with the requirements of 40 CFR 61, Subpart H (2010). The report includes estimation of the effective dose equivalent to an MEI member of the public and comparison to the 10-mrem/year standard. In 2013, the estimated effective dose equivalent from activities at the INL Site to an MEI located at Frenchman's Cabin (south of RWMC) was 0.03 mrem/year, less than 1\% of the standard (DOE-ID 2014c). 


\subsection{Radionuclides of Concern and Release Quantities}

Information on current radiological effluents is contained in the most recent INL Site NESHAP report, titled, National Emission Standards for Hazardous Air Pollutants-Calendar Year 2013 INL Report for Radionuclides, referred to hereafter as the NESHAPs Report (DOE-ID 2014c).

The 2013 NESHAPs Report describes the following three categories of airborne emissions:

- Releases that require continuous monitoring under the NESHAPs regulation

- Releases from other point sources

- Releases from nonpoint, or diffuse sources, which include radioactive waste ponds, contaminated soil areas, and decontaminated and decommissioned facility areas.

The estimated 2013 radionuclide emissions from all INL Site sources are provided in Table 2. During 2013, an estimated 2,890 $\mathrm{Ci}(1.07 \mathrm{E}+14 \mathrm{~Bq})$ of radioactivity were released to the atmosphere, which is within the range of releases from previous years and continued the downward trend observed over the last 10 years.

Approximately $77 \%$ of the 2013 radioactive effluent in curies was from the noble gases argon, krypton, and xenon. A noble gas is inert, which means that it exists in a gaseous state and does not enter into chemical combination with other elements. Most of the remaining effluent was tritium (Table 2).

Although the CAP88 code used to demonstrate compliance with NESHAPs assumes releases are constant throughout the year, actual releases will vary during the year depending on the type of operation. The model used in this assessment to evaluate the performance of the air-monitoring network accounts for temporal variability in the source term.

Using information from the 2007 to 2013 NESHAP reports, radionuclides that contribute most to the total dose over the 7-year period are summarized in Table 3. Of the radionuclides that contribute more than $1 \%$ of the total dose, only Ar-41 and I-129 are not monitored for by the current sampling network. Ar-41 is a noble gas and cannot be detected using particulate filters. Sampling and analysis of I-129 is prohibitively expensive. However, the remainder of the radionuclides that contribute more than $1 \%$ to total dose are routinely analyzed for. For this analysis, sampler network performance is based on H-3, Cs-137, $\mathrm{Pu}-239 / 240$, Sr-90, Am-241, and Pu-238. Although I-131 does not show up as an important radionuclide, it has the potential to be an important radionuclide in reactor effluent (especially during an accident) and fuel reprocessing, and is routinely analyzed for. For these reasons, it is also included in the analysis. Tritium monitoring and measurements are characteristically different than those for particulates and iodine. These differences in monitoring and measurement methods are included in the modeling methodology.

\subsection{Air Dispersion Modeling and Frequency of Detection Methodology}

Rood and Sondrup (2014) developed a methodology and modeling tool that can be used to objectively assess an air monitoring network design against established performance objectives. For input, the model takes unit-activity time-integrated concentrations (TICs) at discrete sampler locations (either real or hypothetical), sampler flow rates, sampling times, release quantities, release durations, and minimum detectable activity (MDA) levels. Using these data, the model calculates FD at the samplers, which is defined as a fraction of "events" that result in a detection at either a single sampler or network of samplers. An "event" is defined as a release of finite duration that begins on a given day and hour of the year. A "detection" is recorded if the activity accumulated on or in the measurement device (i.e., a filter) is greater than the MDA. The model steps through each hour of the year, releasing the activity over the release time and calculates the FD for both individual samplers and the network of samplers. 
Table 2. Radionuclide composition of INL Site airborne effluents (2013). ${ }^{a}$

\begin{tabular}{|c|c|c|c|c|c|c|c|c|c|c|}
\hline \multirow[b]{2}{*}{ Radionuclide } & \multirow[b]{2}{*}{ Half-Life ${ }^{d}$} & \multicolumn{9}{|c|}{ Estimated Emissions $(\mathbf{C i})^{\mathbf{b}, \mathbf{c}}$} \\
\hline & & $\begin{array}{c}\text { ATR } \\
\text { Complex }\end{array}$ & CFA & CITRC & INTEC & MFC & NRF & RWMC & $\begin{array}{l}\text { TAN/ } \\
\text { SMC }\end{array}$ & Total \\
\hline Ac-228 & $6.15 \mathrm{~h}$ & - & $1.83 \mathrm{E}-12$ & - & - & - & - & - & - & $1.83 \mathrm{E}-12$ \\
\hline $\mathrm{Ag}-110 \mathrm{~m}$ & $249.9 \mathrm{~d}$ & $1.96 \mathrm{E}-06$ & - & - & $1.96 \mathrm{E}-13$ & - & - & - & - & $1.96 \mathrm{E}-06$ \\
\hline Am-241 & $432.2 \mathrm{y}$ & $7.03 \mathrm{E}-05$ & $1.59 \mathrm{E}-09$ & - & $5.67 \mathrm{E}-08$ & $2.31 \mathrm{E}-11$ & - & $1.13 \mathrm{E}-04$ & - & $1.83 \mathrm{E}-04$ \\
\hline Am-242m & $152 y$ & - & - & - & - & - & - & $2.84 \mathrm{E}-17$ & - & $2.84 \mathrm{E}-17$ \\
\hline Am-243 & $7380 y$ & $4.34 \mathrm{E}-15$ & $1.60 \mathrm{E}-09$ & - & - & 3.39E-07 & - & - & - & $3.41 \mathrm{E}-07$ \\
\hline Ar-39 & $269 y$ & $1.48 \mathrm{E}-19$ & - & - & - & - & - & - & - & $1.48 \mathrm{E}-19$ \\
\hline Ar-41 & $1.827 \mathrm{~h}$ & $1.14 \mathrm{E}+03$ & - & - & - & - & - & - & - & $1.14 \mathrm{E}+03$ \\
\hline Ba-133 & $10.74 \mathrm{y}$ & $5.67 \mathrm{E}-12$ & $1.91 \mathrm{E}-12$ & - & - & $6.03 \mathrm{E}-10$ & - & - & - & $6.11 \mathrm{E}-10$ \\
\hline Ba-137m & $2.552 \mathrm{~m}$ & - & - & - & - & $1.14 \mathrm{E}-07$ & - & - & - & $1.14 \mathrm{E}-07$ \\
\hline Ba-139 & $82.7 \mathrm{~m}$ & $1.18 \mathrm{E}-02$ & - & - & - & - & - & - & - & $1.18 \mathrm{E}-02$ \\
\hline Ba-140 & $12.74 \mathrm{~d}$ & $2.34 \mathrm{E}-06$ & - & - & - & - & - & - & - & $2.34 \mathrm{E}-06$ \\
\hline Ba-141 & $18.27 \mathrm{~m}$ & $2.58 \mathrm{E}-09$ & - & - & - & - & - & - & - & $2.58 \mathrm{E}-09$ \\
\hline $\mathrm{Be}-7$ & $53.3 \mathrm{~d}$ & - & - & - & - & - & - & $1.19 \mathrm{E}-12$ & - & $1.19 \mathrm{E}-12$ \\
\hline Be-10 & $1.6 \mathrm{E}+06 \mathrm{y}$ & $5.43 \mathrm{E}-20$ & - & - & - & - & - & - & - & $5.43 \mathrm{E}-20$ \\
\hline Bi-207 & $38 \mathrm{y}$ & - & $7.50 \mathrm{E}-12$ & - & - & - & - & - & - & $7.50 \mathrm{E}-12$ \\
\hline Bi-210 & $5.01 \mathrm{~d}$ & $7.68 \mathrm{E}-22$ & - & - & - & - & - & - & - & $7.68 \mathrm{E}-22$ \\
\hline $\mathrm{Bi}-210 \mathrm{~m}$ & $3.0 \mathrm{E}+06 \mathrm{y}$ & $5.73 \mathrm{E}-28$ & - & - & - & - & - & - & - & $5.73 \mathrm{E}-28$ \\
\hline Bi-212 & $60.55 \mathrm{~m}$ & - & $1.83 \mathrm{E}-12$ & - & - & - & - & $4.48 \mathrm{E}-18$ & - & $1.83 \mathrm{E}-12$ \\
\hline $\mathrm{Br}-83$ & $2.39 \mathrm{~h}$ & $1.04 \mathrm{E}-05$ & - & - & - & - & - & - & - & $1.04 \mathrm{E}-05$ \\
\hline C-14 & $5730 y$ & $6.28 \mathrm{E}-11$ & 5.83E-07 & - & $1.33 \mathrm{E}-05$ & $9.16 \mathrm{E}-04$ & $7.30 \mathrm{E}-01$ & $3.43 \mathrm{E}-01$ & - & $1.07 \mathrm{E}+00$ \\
\hline $\mathrm{Ca}-45$ & $163 \mathrm{~d}$ & $3.27 \mathrm{E}-14$ & - & - & - & - & - & - & - & $3.27 \mathrm{E}-14$ \\
\hline Cd-109 & $464 \mathrm{~d}$ & $3.33 \mathrm{E}-14$ & $4.98 \mathrm{E}-19$ & - & - & $1.62 \mathrm{E}-11$ & - & - & - & $1.62 \mathrm{E}-11$ \\
\hline Ce-139 & $137.66 \mathrm{~d}$ & - & $4.61 \mathrm{E}-10$ & - & - & - & - & - & - & $4.61 \mathrm{E}-10$ \\
\hline Ce-141 & $32.501 \mathrm{~d}$ & $1.02 \mathrm{E}-10$ & - & - & - & - & - & $6.42 \mathrm{E}-11$ & - & $1.66 \mathrm{E}-10$ \\
\hline Ce-144 & $284.3 \mathrm{~d}$ & $6.96 \mathrm{E}-04$ & - & - & - & $3.19 \mathrm{E}-11$ & - & $5.84 \mathrm{E}-08$ & - & $6.96 \mathrm{E}-04$ \\
\hline $\mathrm{Cl}-36$ & $3.01 \mathrm{E}+05 \mathrm{y}$ & - & - & - & $8.72 \mathrm{E}-07$ & - & - & - & - & $8.72 \mathrm{E}-07$ \\
\hline $\mathrm{Cm}-242$ & $162.8 \mathrm{~d}$ & $6.60 \mathrm{E}-15$ & - & - & - & - & - & - & - & $6.60 \mathrm{E}-15$ \\
\hline $\mathrm{Cm}-243$ & $28.5 \mathrm{y}$ & $1.24 \mathrm{E}-14$ & - & - & - & - & - & - & - & $1.24 \mathrm{E}-14$ \\
\hline $\mathrm{Cm}-244$ & $18.11 \mathrm{y}$ & $9.79 \mathrm{E}-14$ & $1.46 \mathrm{E}-08$ & - & $3.65 \mathrm{E}-17$ & $5.36 \mathrm{E}-12$ & - & $9.08 \mathrm{E}-17$ & - & $1.46 \mathrm{E}-08$ \\
\hline $\mathrm{Cm}-248$ & $3.39 \mathrm{E}+05 \mathrm{y}$ & - & - & - & - & $5.22 \mathrm{E}-10$ & - & - & - & $5.22 \mathrm{E}-10$ \\
\hline Co-57 & $270.9 \mathrm{~d}$ & $1.03 \mathrm{E}-11$ & $3.87 \mathrm{E}-21$ & - & - & $1.62 \mathrm{E}-11$ & - & $2.20 \mathrm{E}-16$ & - & $2.65 \mathrm{E}-11$ \\
\hline Co-58 & $70.80 \mathrm{~d}$ & $2.51 \mathrm{E}-05$ & $1.10 \mathrm{E}-14$ & - & - & $6.40 \mathrm{E}-11$ & - & $1.22 \mathrm{E}-09$ & - & $2.51 \mathrm{E}-05$ \\
\hline
\end{tabular}


Table 2. (continued).

\begin{tabular}{|c|c|c|c|c|c|c|c|c|c|c|}
\hline \multirow[b]{2}{*}{ Radionuclide } & \multirow[b]{2}{*}{ Half-Life ${ }^{\mathrm{d}}$} & \multicolumn{9}{|c|}{ Estimated Emissions (Ci) ${ }^{b, c}$} \\
\hline & & $\begin{array}{c}\text { ATR } \\
\text { Complex }\end{array}$ & CFA & CITRC & INTEC & MFC & NRF & RWMC & $\begin{array}{l}\text { TAN/ } \\
\text { SMC }\end{array}$ & Total \\
\hline Co- 60 & $5.271 \mathrm{y}$ & $2.46 \mathrm{E}-02$ & $1.45 \mathrm{E}-10$ & - & $4.50 \mathrm{E}-05$ & $2.40 \mathrm{E}-08$ & $5.10 \mathrm{E}-08$ & $1.47 \mathrm{E}-09$ & - & $2.46 \mathrm{E}-02$ \\
\hline Co-60m & $10.47 \mathrm{~m}$ & $1.03 \mathrm{E}-19$ & - & - & - & - & - & - & - & $1.03 \mathrm{E}-19$ \\
\hline Cr-51 & $27.704 \mathrm{~d}$ & $6.03 \mathrm{E}-03$ & $2.02 \mathrm{E}-13$ & - & - & $6.56 \mathrm{E}-11$ & - & - & - & $6.03 \mathrm{E}-03$ \\
\hline Cs-134 & $2.062 \mathrm{y}$ & $3.16 \mathrm{E}-05$ & $4.06 \mathrm{E}-13$ & - & $1.20 \mathrm{E}-07$ & $2.36 \mathrm{E}-09$ & - & $1.53 \mathrm{E}-09$ & - & $3.17 \mathrm{E}-05$ \\
\hline Cs-137 & $30.0 \mathrm{y}$ & $2.06 \mathrm{E}-02$ & $2.73 \mathrm{E}-11$ & - & $1.71 \mathrm{E}-02$ & $1.14 \mathrm{E}-05$ & $8.40 \mathrm{E}-05$ & $1.37 \mathrm{E}-07$ & - & $3.78 \mathrm{E}-02$ \\
\hline Cs-138 & $32.2 \mathrm{~m}$ & $2.78 \mathrm{E}-01$ & - & - & - & - & - & - & - & $2.78 \mathrm{E}-01$ \\
\hline Eu-152 & $13.33 \mathrm{y}$ & $4.08 \mathrm{E}-04$ & $4.81 \mathrm{E}-13$ & - & $4.25 \mathrm{E}-15$ & - & - & $9.88 \mathrm{E}-14$ & - & $4.08 \mathrm{E}-04$ \\
\hline Eu-154 & $8.8 \mathrm{y}$ & $3.46 \mathrm{E}-04$ & $1.68 \mathrm{E}-09$ & - & $3.59 \mathrm{E}-05$ & $6.08 \mathrm{E}-09$ & - & 4.82E-09 & - & $3.82 \mathrm{E}-04$ \\
\hline Eu-155 & $4.96 \mathrm{y}$ & $6.29 \mathrm{E}-05$ & - & - & $9.98 \mathrm{E}-06$ & $3.14 \mathrm{E}-10$ & - & $7.00 \mathrm{E}-09$ & - & 7.29E-05 \\
\hline Eu-156 & $15.19 \mathrm{~d}$ & $3.48 \mathrm{E}-11$ & - & - & - & - & - & - & - & $3.48 \mathrm{E}-11$ \\
\hline $\mathrm{Fe}-55$ & $2.7 \mathrm{y}$ & 3.79E-09 & $3.87 \mathrm{E}-14$ & - & - & $1.02 \mathrm{E}-09$ & - & $2.52 \mathrm{E}-11$ & - & $4.83 \mathrm{E}-09$ \\
\hline $\mathrm{Fe}-59$ & $44.529 \mathrm{~d}$ & $6.42 \mathrm{E}-08$ & - & - & - & $5.08 \mathrm{E}-11$ & - & - & - & $6.43 \mathrm{E}-08$ \\
\hline $\mathrm{Fe}-60$ & $1.0 \mathrm{E}+05 \mathrm{y}$ & $1.03 \mathrm{E}-19$ & - & - & - & - & - & - & - & $1.03 \mathrm{E}-19$ \\
\hline Gd-153 & $242 \mathrm{~d}$ & - & $1.67 \mathrm{E}-09$ & - & - & - & - & - & - & $1.67 \mathrm{E}-09$ \\
\hline Ge-71 & $11.8 \mathrm{~d}$ & $3.21 \mathrm{E}-19$ & - & - & - & - & - & - & - & $3.21 \mathrm{E}-19$ \\
\hline H-3 & $12.35 \mathrm{y}$ & $3.78 \mathrm{E}+02$ & $9.20 \mathrm{E}-01$ & - & $1.41 \mathrm{E}+02$ & $2.00 \mathrm{E}-01$ & $1.70 \mathrm{E}-02$ & $8.10 \mathrm{E}+01$ & $3.26 \mathrm{E}-02$ & $6.01 \mathrm{E}+02$ \\
\hline Hf- 175 & $70 \mathrm{~d}$ & $4.43 \mathrm{E}-07$ & - & - & - & - & - & - & - & $4.43 \mathrm{E}-07$ \\
\hline Hf- $178 \mathrm{~m}$ & $31 \mathrm{y}$ & $2.35 \mathrm{E}-20$ & - & - & - & - & - & - & - & $2.35 \mathrm{E}-20$ \\
\hline Hf- $179 m$ & $25.1 \mathrm{~d}$ & $5.34 \mathrm{E}-20$ & - & - & - & - & - & - & - & $5.34 \mathrm{E}-20$ \\
\hline Hf-181 & $42.4 \mathrm{~d}$ & $5.51 \mathrm{E}-05$ & $4.10 \mathrm{E}-14$ & - & - & - & - & - & - & $5.51 \mathrm{E}-05$ \\
\hline Hf-182 & $9 E+06 y$ & $2.55 \mathrm{E}-23$ & - & - & - & - & - & - & - & $2.55 \mathrm{E}-23$ \\
\hline $\mathrm{Hg}-203$ & $46.6 \mathrm{~d}$ & $3.14 \mathrm{E}-06$ & - & - & - & - & - & - & - & $3.14 \mathrm{E}-06$ \\
\hline Но-166m & $1.20 \mathrm{E}+03 \mathrm{y}$ & - & $1.77 \mathrm{E}-10$ & - & - & - & - & - & - & $1.77 \mathrm{E}-10$ \\
\hline $\mathrm{I}-128$ & $24.99 \mathrm{~m}$ & $2.05 \mathrm{E}-02$ & - & - & - & - & - & - & - & $2.05 \mathrm{E}-02$ \\
\hline I-129 & $1.57 \mathrm{E}+07 \mathrm{y}$ & $1.08 \mathrm{E}-07$ & 1.99E-09 & - & $2.50 \mathrm{E}-02$ & $1.59 \mathrm{E}-07$ & $3.80 \mathrm{E}-05$ & - & - & $2.50 \mathrm{E}-02$ \\
\hline I-131 & $8.04 \mathrm{~d}$ & $3.42 \mathrm{E}-03$ & - & - & - & $5.06 \mathrm{E}-03$ & $4.10 \mathrm{E}-06$ & - & - & $8.48 \mathrm{E}-03$ \\
\hline I-132 & $2.3 \mathrm{~h}$ & $1.68 \mathrm{E}-04$ & - & - & - & - & - & - & - & $1.68 \mathrm{E}-04$ \\
\hline $\mathrm{I}-133$ & $20.8 \mathrm{~h}$ & $1.07 \mathrm{E}-03$ & - & - & - & - & - & - & - & $1.07 \mathrm{E}-03$ \\
\hline $\mathrm{I}-134$ & $52.8 \mathrm{~m}$ & $1.98 \mathrm{E}-04$ & - & - & - & - & - & - & - & $1.98 \mathrm{E}-04$ \\
\hline I-135 & $6.61 \mathrm{~h}$ & $3.84 \mathrm{E}-04$ & - & - & - & - & - & - & - & $3.84 \mathrm{E}-04$ \\
\hline Ir-192 & $74.02 \mathrm{~d}$ & $5.76 \mathrm{E}-21$ & - & - & - & - & - & - & - & $5.76 \mathrm{E}-21$ \\
\hline K-40 & $1.28 \mathrm{E}+08 \mathrm{y}$ & $4.05 \mathrm{E}-14$ & - & - & - & - & - & $1.59 \mathrm{E}-12$ & - & $1.63 \mathrm{E}-12$ \\
\hline $\mathrm{Kr}-85$ & $10.72 \mathrm{y}$ & $1.60 \mathrm{E}-08$ & - & - & $1.00 \mathrm{E}+03$ & $8.27 \mathrm{E}-03$ & $2.20 \mathrm{E}-02$ & $1.16 \mathrm{E}-18$ & - & $1.00 \mathrm{E}+03$ \\
\hline
\end{tabular}


Table 2. (continued).

\begin{tabular}{|c|c|c|c|c|c|c|c|c|c|c|}
\hline \multirow[b]{2}{*}{ Radionuclide } & \multirow[b]{2}{*}{ Half-Life ${ }^{\mathrm{d}}$} & \multicolumn{9}{|c|}{ Estimated Emissions (Ci) ${ }^{\mathbf{b , c}}$} \\
\hline & & $\begin{array}{c}\text { ATR } \\
\text { Complex }\end{array}$ & CFA & CITRC & INTEC & MFC & NRF & RWMC & $\begin{array}{l}\text { TAN/ } \\
\text { SMC }\end{array}$ & Total \\
\hline $\mathrm{Kr}-85 \mathrm{~m}$ & $4.48 \mathrm{~h}$ & $8.12 \mathrm{E}+00$ & - & - & - & - & - & - & - & $8.12 \mathrm{E}+00$ \\
\hline $\mathrm{Kr}-87$ & $76.3 \mathrm{~m}$ & $2.69 \mathrm{E}+01$ & - & - & - & - & - & - & - & $2.69 \mathrm{E}+01$ \\
\hline $\mathrm{Kr}-88$ & $2.84 \mathrm{~m}$ & $2.37 \mathrm{E}+01$ & - & - & - & - & - & - & - & $2.37 \mathrm{E}+01$ \\
\hline La-140 & $40.27 \mathrm{~h}$ & $4.43 \mathrm{E}-07$ & - & - & - & - & - & - & - & $4.43 \mathrm{E}-07$ \\
\hline La-142 & $92.5 \mathrm{~m}$ & $1.20 \mathrm{E}-12$ & - & - & - & - & - & - & - & $1.20 \mathrm{E}-12$ \\
\hline Mn-53 & $3.7 \mathrm{E}+06 \mathrm{y}$ & $7.20 \mathrm{E}-23$ & - & - & - & - & - & - & - & $7.20 \mathrm{E}-23$ \\
\hline Mn-54 & $312.5 \mathrm{~d}$ & $3.45 \mathrm{E}-05$ & $8.39 \mathrm{E}-13$ & - & - & $2.10 \mathrm{E}-10$ & - & $1.23 \mathrm{E}-09$ & - & $3.45 \mathrm{E}-05$ \\
\hline Mn-56 & $2.5785 \mathrm{~h}$ & $1.14 \mathrm{E}-11$ & - & - & - & - & - & - & - & $1.14 \mathrm{E}-11$ \\
\hline Mo-93 & $3.5 \mathrm{E}+03 \mathrm{y}$ & $1.01 \mathrm{E}-09$ & - & - & - & - & - & - & - & $1.01 \mathrm{E}-09$ \\
\hline Mo-99 & $66.0 \mathrm{~h}$ & $8.10 \mathrm{E}-05$ & - & - & - & - & - & - & - & $8.10 \mathrm{E}-05$ \\
\hline $\mathrm{Na}-22$ & $2.602 \mathrm{y}$ & - & $6.00 \mathrm{E}-10$ & - & - & $1.19 \mathrm{E}-08$ & - & - & - & $1.25 \mathrm{E}-08$ \\
\hline $\mathrm{Na}-24$ & $15.0 \mathrm{~h}$ & $1.85 \mathrm{E}-03$ & - & - & - & - & - & - & - & $1.85 \mathrm{E}-03$ \\
\hline $\mathrm{Nb}-93 \mathrm{~m}$ & $13.6 \mathrm{y}$ & $6.48 \mathrm{E}-13$ & - & - & - & - & - & - & - & $6.48 \mathrm{E}-13$ \\
\hline $\mathrm{Nb}-94$ & $2.03 \mathrm{E}+04 \mathrm{y}$ & $3.21 \mathrm{E}-14$ & - & - & - & - & - & - & - & $3.21 \mathrm{E}-14$ \\
\hline $\mathrm{Nb}-95$ & $35.15 \mathrm{~d}$ & $1.23 \mathrm{E}-06$ & $1.96 \mathrm{E}-14$ & - & - & $8.24 \mathrm{E}-12$ & - & $3.08 \mathrm{E}-16$ & - & $1.23 \mathrm{E}-06$ \\
\hline $\mathrm{Nb}-97$ & $72.1 \mathrm{~m}$ & - & - & - & - & $4.80 \mathrm{E}-12$ & - & - & - & $4.80 \mathrm{E}-12$ \\
\hline Ni-59 & $7.5 \mathrm{E}+04 \mathrm{y}$ & $3.05 \mathrm{E}-10$ & $6.03 \mathrm{E}-15$ & - & - & - & - & - & - & $3.05 \mathrm{E}-10$ \\
\hline $\mathrm{Ni}-63$ & $96 y$ & $4.84 \mathrm{E}-08$ & $1.78 \mathrm{E}-12$ & - & $1.10 \mathrm{E}-04$ & $1.18 \mathrm{E}-10$ & - & $1.60 \mathrm{E}-13$ & - & $1.10 \mathrm{E}-04$ \\
\hline Np-237 & $2.14 \mathrm{E}+06 \mathrm{y}$ & $6.11 \mathrm{E}-10$ & $2.27 \mathrm{E}-12$ & - & $5.95 \mathrm{E}-17$ & $6.36 \mathrm{E}-08$ & - & $6.79 \mathrm{E}-09$ & - & $7.10 \mathrm{E}-08$ \\
\hline Np-239 & $2.355 \mathrm{~d}$ & $9.94 \mathrm{E}-05$ & - & - & - & - & - & - & - & $9.94 \mathrm{E}-05$ \\
\hline Os-185 & $94 \mathrm{~d}$ & $4.44 \mathrm{E}-21$ & - & - & - & - & - & - & - & $4.44 \mathrm{E}-21$ \\
\hline Os-191 & $15.4 \mathrm{~d}$ & $1.67 \mathrm{E}-05$ & - & - & - & - & - & - & - & $1.67 \mathrm{E}-05$ \\
\hline P-32 & $14.29 \mathrm{~d}$ & $5.88 \mathrm{E}-18$ & $3.00 \mathrm{E}-10$ & - & - & - & - & - & - & $3.00 \mathrm{E}-10$ \\
\hline P-33 & $25.4 \mathrm{~d}$ & $3.15 \mathrm{E}-21$ & - & - & - & - & - & - & - & $3.15 \mathrm{E}-21$ \\
\hline $\mathrm{Pa}-233$ & $27.0 \mathrm{~d}$ & - & $2.55 \mathrm{E}-13$ & - & - & - & - & - & - & $2.55 \mathrm{E}-13$ \\
\hline $\mathrm{Pb}-205$ & $1.43 \mathrm{E}+07 \mathrm{y}$ & $1.72 \mathrm{E}-21$ & - & - & - & - & - & - & - & $1.72 \mathrm{E}-21$ \\
\hline $\mathrm{Pb}-210$ & $22.3 \mathrm{y}$ & $1.11 \mathrm{E}-13$ & - & - & - & - & - & $3.59 \mathrm{E}-13$ & - & $4.70 \mathrm{E}-13$ \\
\hline $\mathrm{Pb}-212$ & $10.64 \mathrm{~h}$ & - & $1.83 \mathrm{E}-12$ & - & - & - & - & $4.48 \mathrm{E}-18$ & - & $1.83 \mathrm{E}-12$ \\
\hline Pm-147 & $2.6234 \mathrm{y}$ & - & $4.29 \mathrm{E}-11$ & - & $1.10 \mathrm{E}-05$ & - & - & $1.03 \mathrm{E}-12$ & - & $1.10 \mathrm{E}-05$ \\
\hline Po-210 & $138.38 \mathrm{~d}$ & $3.03 \mathrm{E}-21$ & - & - & - & - & - & - & - & $3.03 \mathrm{E}-21$ \\
\hline Po-212 & $0.305 \mu \mathrm{s}$ & - & $1.17 \mathrm{E}-12$ & - & - & - & - & $2.86 \mathrm{E}-18$ & - & $1.17 \mathrm{E}-12$ \\
\hline Po-216 & $0.15 \mathrm{~s}$ & - & $1.83 \mathrm{E}-12$ & - & - & - & - & $4.48 \mathrm{E}-18$ & - & $1.83 \mathrm{E}-12$ \\
\hline Pr-144 & $17.28 \mathrm{~m}$ & - & - & - & - & $2.29 \mathrm{E}-11$ & - & $4.58 \mathrm{E}-18$ & - & $2.29 \mathrm{E}-11$ \\
\hline
\end{tabular}


Table 2. (continued).

\begin{tabular}{|c|c|c|c|c|c|c|c|c|c|c|}
\hline \multirow[b]{2}{*}{ Radionuclide } & \multirow[b]{2}{*}{ Half-Life ${ }^{\mathrm{d}}$} & \multicolumn{9}{|c|}{ Estimated Emissions (Ci) ${ }^{\mathbf{b , c}}$} \\
\hline & & $\begin{array}{c}\text { ATR } \\
\text { Complex }\end{array}$ & CFA & CITRC & INTEC & MFC & NRF & RWMC & $\begin{array}{l}\text { TAN/ } \\
\text { SMC }\end{array}$ & Total \\
\hline Pr-144m & $7.2 \mathrm{~m}$ & - & - & - & - & - & - & $8.66 \mathrm{E}-15$ & - & $8.66 \mathrm{E}-15$ \\
\hline $\mathrm{Pu}-236$ & $2.851 \mathrm{y}$ & $1.60 \mathrm{E}-14$ & - & - & - & - & - & - & - & $1.60 \mathrm{E}-14$ \\
\hline $\mathrm{Pu}-238$ & $87.74 \mathrm{y}$ & $4.06 \mathrm{E}-14$ & $4.98 \mathrm{E}-16$ & - & $5.91 \mathrm{E}-05$ & $1.42 \mathrm{E}-17$ & - & $4.45 \mathrm{E}-06$ & - & $6.36 \mathrm{E}-05$ \\
\hline $\mathrm{Pu}-239$ & $24065 y$ & $2.67 \mathrm{E}-05$ & $2.40 \mathrm{E}-11$ & - & $2.60 \mathrm{E}-04$ & $3.43 \mathrm{E}-07$ & $2.90 \mathrm{E}-06$ & $1.81 \mathrm{E}-04$ & - & $4.71 \mathrm{E}-04$ \\
\hline $\mathrm{Pu}-240$ & $6537 \mathrm{y}$ & $1.29 \mathrm{E}-14$ & $6.09 \mathrm{E}-17$ & - & $1.30 \mathrm{E}-04$ & $1.42 \mathrm{E}-11$ & - & $3.73 \mathrm{E}-05$ & - & $1.67 \mathrm{E}-04$ \\
\hline $\mathrm{Pu}-241$ & $14.4 \mathrm{y}$ & $2.45 \mathrm{E}-14$ & $1.80 \mathrm{E}-13$ & - & $4.60 \mathrm{E}-03$ & $3.61 \mathrm{E}-10$ & - & $1.94 \mathrm{E}-04$ & - & 4.79E-03 \\
\hline $\mathrm{Pu}-242$ & $3.76 \mathrm{E}+05 \mathrm{y}$ & $1.25 \mathrm{E}-13$ & $9.58 \mathrm{E}-11$ & - & - & - & - & $2.71 \mathrm{E}-09$ & - & $2.81 \mathrm{E}-09$ \\
\hline $\mathrm{Ra}-224$ & $3.66 \mathrm{~d}$ & - & $1.83 \mathrm{E}-12$ & - & - & - & - & $4.48 \mathrm{E}-18$ & - & $1.83 \mathrm{E}-12$ \\
\hline $\mathrm{Ra}-226$ & $1600 y$ & $3.12 \mathrm{E}-10$ & - & - & - & - & - & $2.63 \mathrm{E}-11$ & - & $3.38 \mathrm{E}-10$ \\
\hline Ra-228 & $5.75 \mathrm{y}$ & & $1.83 \mathrm{E}-12$ & - & & & - & & & $1.83 \mathrm{E}-12$ \\
\hline $\mathrm{Rb}-88$ & $17.8 \mathrm{~m}$ & $3.15 \mathrm{E}-01$ & - & - & - & - & - & - & - & $3.15 \mathrm{E}-01$ \\
\hline $\mathrm{Rb}-89$ & $15.2 \mathrm{~m}$ & $1.79 \mathrm{E}-01$ & - & - & - & - & - & - & - & $1.79 \mathrm{E}-01$ \\
\hline Re-184 & $38.0 \mathrm{~d}$ & $3.06 \mathrm{E}-18$ & - & - & - & - & - & - & - & $3.06 \mathrm{E}-18$ \\
\hline Re-184m & $165 \mathrm{~d}$ & $2.35 \mathrm{E}-18$ & - & - & - & - & - & - & - & $2.35 \mathrm{E}-18$ \\
\hline Re-186 & $90.64 \mathrm{~h}$ & $8.28 \mathrm{E}-20$ & - & - & - & - & - & - & - & $8.28 \mathrm{E}-20$ \\
\hline Re-186m & $2.0 \mathrm{E}+05 \mathrm{y}$ & $8.28 \mathrm{E}-20$ & - & - & - & - & - & - & - & $8.28 \mathrm{E}-20$ \\
\hline Re-187 & $5 \mathrm{E}+10 \mathrm{y}$ & $3.45 \mathrm{E}-17$ & - & - & - & - & - & - & - & $3.45 \mathrm{E}-17$ \\
\hline $\operatorname{Re}-188$ & $16.98 \mathrm{~h}$ & $6.87 \mathrm{E}-04$ & - & - & - & - & - & - & - & $6.87 \mathrm{E}-04$ \\
\hline Rh-106 & $29.9 \mathrm{~s}$ & $5.09 \mathrm{E}-06$ & - & - & - & $5.07 \mathrm{E}-12$ & - & $1.10 \mathrm{E}-09$ & - & $5.09 \mathrm{E}-06$ \\
\hline $\mathrm{Rn}-220$ & $55.6 \mathrm{~s}$ & - & $1.83 \mathrm{E}-12$ & - & - & - & - & - & - & $1.83 \mathrm{E}-12$ \\
\hline $\mathrm{Ru}-103$ & $39.28 \mathrm{~d}$ & $4.92 \mathrm{E}-11$ & & - & & & - & & & $4.92 \mathrm{E}-11$ \\
\hline $\mathrm{Ru}-106$ & $368.2 \mathrm{~d}$ & - & - & - & - & $5.07 \mathrm{E}-12$ & - & $1.01 \mathrm{E}-09$ & - & $1.02 \mathrm{E}-09$ \\
\hline Sb-122 & $2.7 \mathrm{~d}$ & $1.66 \mathrm{E}-06$ & - & - & - & - & - & - & - & $1.66 \mathrm{E}-06$ \\
\hline Sb-124 & $60.2 \mathrm{~d}$ & $3.16 \mathrm{E}-06$ & $7.21 \mathrm{E}-14$ & - & - & - & - & $4.06 \mathrm{E}-10$ & - & $3.16 \mathrm{E}-06$ \\
\hline Sb-125 & $2.77 \mathrm{y}$ & $2.28 \mathrm{E}-11$ & $1.33 \mathrm{E}-13$ & - & $1.00 \mathrm{E}-06$ & 7.29E-08 & - & $3.66 \mathrm{E}-10$ & - & $1.07 \mathrm{E}-06$ \\
\hline Sc-46 & $83.83 \mathrm{~d}$ & $1.90 \mathrm{E}-07$ & $1.84 \mathrm{E}-14$ & - & - & - & - & - & - & $1.90 \mathrm{E}-07$ \\
\hline $\mathrm{Si}-32$ & $450 \mathrm{y}$ & 5.34E-18 & - & - & - & - & - & - & - & $5.34 \mathrm{E}-18$ \\
\hline Sm-151 & $90 \mathrm{y}$ & - & - & - & $1.90 \mathrm{E}-04$ & - & - & - & - & $1.90 \mathrm{E}-04$ \\
\hline Sn-113 & $115.1 \mathrm{~d}$ & $5.76 \mathrm{E}-12$ & - & - & - & $1.62 \mathrm{E}-11$ & - & - & - & $2.20 \mathrm{E}-11$ \\
\hline Sr-85 & $64.84 \mathrm{~d}$ & $3.00 \mathrm{E}-10$ & - & - & $1.50 \mathrm{E}-11$ & $7.35 \mathrm{E}-09$ & - & - & - & 7.67E-09 \\
\hline Sr-89 & $50.5 \mathrm{~d}$ & $2.17 \mathrm{E}-06$ & - & - & - & $5.37 \mathrm{E}-06$ & - & - & - & $7.54 \mathrm{E}-06$ \\
\hline Sr-90 & $29.12 \mathrm{y}$ & $4.24 \mathrm{E}-02$ & $4.32 \mathrm{E}-13$ & - & $9.55 \mathrm{E}-03$ & - & $6.00 \mathrm{E}-05$ & $1.51 \mathrm{E}-07$ & $1.02 \mathrm{E}-06$ & $5.20 \mathrm{E}-02$ \\
\hline Sr-91 & $9.5 \mathrm{~h}$ & $1.30 \mathrm{E}-10$ & - & - & - & - & - & - & - & $1.30 \mathrm{E}-10$ \\
\hline
\end{tabular}


Table 2. (continued).

\begin{tabular}{|c|c|c|c|c|c|c|c|c|c|c|}
\hline \multirow[b]{2}{*}{ Radionuclide } & \multirow[b]{2}{*}{ Half-Life ${ }^{\mathrm{d}}$} & \multicolumn{9}{|c|}{ Estimated Emissions (Ci) ${ }^{\mathbf{b , c}}$} \\
\hline & & $\begin{array}{c}\text { ATR } \\
\text { Complex }\end{array}$ & CFA & CITRC & INTEC & MFC & NRF & RWMC & $\begin{array}{l}\text { TAN/ } \\
\text { SMC }\end{array}$ & Total \\
\hline Sr-92 & $2.7 \mathrm{~h}$ & $1.02 \mathrm{E}-10$ & - & - & - & - & - & - & - & $1.02 \mathrm{E}-10$ \\
\hline Тa-179 & $664.9 \mathrm{~d}$ & $1.34 \mathrm{E}-14$ & - & - & - & - & - & - & - & $1.34 \mathrm{E}-14$ \\
\hline Ta-180m & $8.1 \mathrm{~h}$ & $5.01 \mathrm{E}-33$ & - & - & - & - & - & - & - & $5.01 \mathrm{E}-33$ \\
\hline Ta-182 & $115 \mathrm{~d}$ & $1.20 \mathrm{E}-05$ & - & - & - & - & - & - & - & $1.20 \mathrm{E}-05$ \\
\hline Ta-183 & $5.1 \mathrm{~d}$ & $5.94 \mathrm{E}-10$ & - & - & - & - & - & - & - & $5.94 \mathrm{E}-10$ \\
\hline Tc-99 & $2.13 \mathrm{E}+05 \mathrm{y}$ & $2.08 \mathrm{E}-11$ & $1.70 \mathrm{E}-10$ & - & $2.20 \mathrm{E}-07$ & - & - & - & - & $2.20 \mathrm{E}-07$ \\
\hline Tc-99m & $6.02 \mathrm{~h}$ & $3.71 \mathrm{E}-04$ & $3.48 \mathrm{E}-71$ & $1.50 \mathrm{E}-04$ & - & - & - & - & - & $5.21 \mathrm{E}-04$ \\
\hline $\mathrm{Te}-123 \mathrm{~m}$ & $119.7 \mathrm{~d}$ & $1.32 \mathrm{E}-15$ & - & - & - & - & - & - & - & $1.32 \mathrm{E}-15$ \\
\hline $\mathrm{Te}-125 \mathrm{~m}$ & $58.0 \mathrm{~d}$ & - & - & - & - & $2.11 \mathrm{E}-12$ & - & - & - & $2.11 \mathrm{E}-12$ \\
\hline Тe-129 & $69.6 \mathrm{~m}$ & - & - & - & - & $1.20 \mathrm{E}-12$ & - & - & - & $1.20 \mathrm{E}-12$ \\
\hline Th-228 & $1.9131 \mathrm{y}$ & $2.12 \mathrm{E}-11$ & $1.83 \mathrm{E}-12$ & - & - & - & - & $4.48 \mathrm{E}-18$ & - & $2.30 \mathrm{E}-11$ \\
\hline Th-229 & $7340 y$ & $3.60 \mathrm{E}-16$ & - & - & - & - & - & - & - & $3.60 \mathrm{E}-16$ \\
\hline Th-230 & $7.7 \mathrm{E}+04 \mathrm{y}$ & $2.77 \mathrm{E}-14$ & - & - & - & - & - & - & - & $2.77 \mathrm{E}-14$ \\
\hline Th-232 & $1.4 \mathrm{E}+10 \mathrm{y}$ & $3.03 \mathrm{E}-11$ & $1.86 \mathrm{E}-12$ & - & - & - & - & $1.23 \mathrm{E}-18$ & - & $3.22 \mathrm{E}-11$ \\
\hline Tl-204 & $3.779 \mathrm{y}$ & $3.81 \mathrm{E}-21$ & - & - & - & - & - & - & - & $3.81 \mathrm{E}-21$ \\
\hline Tl-208 & $3.07 \mathrm{~m}$ & $6.86 \mathrm{E}-15$ & $6.57 \mathrm{E}-13$ & - & - & - & - & $1.61 \mathrm{E}-18$ & - & $6.64 \mathrm{E}-13$ \\
\hline U-232 & $72 \mathrm{y}$ & - & $4.44 \mathrm{E}-17$ & - & - & - & - & $4.74 \mathrm{E}-12$ & - & $4.74 \mathrm{E}-12$ \\
\hline U-233 & $1.59 \mathrm{E}+05 \mathrm{y}$ & $1.95 \mathrm{E}-11$ & $7.55 \mathrm{E}-08$ & - & $3.72 \mathrm{E}-08$ & $6.87 \mathrm{E}-06$ & - & $7.92 \mathrm{E}-06$ & - & $1.49 \mathrm{E}-05$ \\
\hline U-234 & $2.45 \mathrm{E}+05 \mathrm{y}$ & $2.64 \mathrm{E}-13$ & $2.58 \mathrm{E}-12$ & - & $2.67 \mathrm{E}-07$ & $2.64 \mathrm{E}-08$ & - & $5.13 \mathrm{E}-09$ & $5.03 \mathrm{E}-09$ & $3.03 \mathrm{E}-07$ \\
\hline U-235 & $7.04 \mathrm{E}+08 \mathrm{y}$ & $5.43 \mathrm{E}-12$ & $1.20 \mathrm{E}-13$ & - & 4.72E-09 & $8.43 \mathrm{E}-10$ & - & $1.59 \mathrm{E}-09$ & $3.52 \mathrm{E}-10$ & $7.51 \mathrm{E}-09$ \\
\hline U-236 & $2.34 \mathrm{E}+07 \mathrm{y}$ & $7.20 \mathrm{E}-16$ & $8.57 \mathrm{E}-11$ & - & $2.48 \mathrm{E}-10$ & $5.40 \mathrm{E}-11$ & - & - & - & $3.88 \mathrm{E}-10$ \\
\hline U-238 & $4.47 \mathrm{E}+09 \mathrm{y}$ & $1.69 \mathrm{E}-09$ & - & - & 2.69E-08 & - & - & $6.04 \mathrm{E}-08$ & $2.80 \mathrm{E}-08$ & $1.17 \mathrm{E}-07$ \\
\hline$V-49$ & $330 \mathrm{~d}$ & $3.21 \mathrm{E}-19$ & - & - & - & - & - & - & - & $3.21 \mathrm{E}-19$ \\
\hline W-181 & $121.2 \mathrm{~d}$ & $4.08 \mathrm{E}-09$ & - & - & - & - & - & - & - & $4.08 \mathrm{E}-09$ \\
\hline W-185 & $75.1 \mathrm{~d}$ & $6.87 \mathrm{E}-08$ & - & - & - & - & - & - & - & $6.87 \mathrm{E}-08$ \\
\hline W-187 & $23.9 \mathrm{~h}$ & $2.46 \mathrm{E}-04$ & - & - & - & - & - & - & - & $2.46 \mathrm{E}-04$ \\
\hline W-188 & $69.4 \mathrm{~d}$ & $2.59 \mathrm{E}-08$ & - & - & - & - & - & - & - & $2.59 \mathrm{E}-08$ \\
\hline Xe-133 & $5.245 \mathrm{~d}$ & $3.80 \mathrm{E}+00$ & - & - & - & - & - & - & - & $3.80 \mathrm{E}+00$ \\
\hline Xe-135 & $9.09 \mathrm{~h}$ & $2.74 \mathrm{E}+01$ & - & - & - & - & - & - & - & $2.74 \mathrm{E}+01$ \\
\hline $\mathrm{Xe}-135 \mathrm{~m}$ & $15.29 \mathrm{~m}$ & $1.19 \mathrm{E}+01$ & - & - & - & - & - & - & - & $1.19 \mathrm{E}+01$ \\
\hline Xe-138 & $14.17 \mathrm{~m}$ & $4.60 \mathrm{E}+01$ & - & - & - & - & - & - & - & $4.60 \mathrm{E}+01$ \\
\hline Y-88 & $106.64 \mathrm{~d}$ & $1.05 \mathrm{E}-14$ & $3.00 \mathrm{E}-10$ & - & - & - & - & - & - & $3.00 \mathrm{E}-10$ \\
\hline$Y-90$ & $64.0 \mathrm{~h}$ & $2.14 \mathrm{E}-03$ & - & - & - & $1.30 \mathrm{E}-07$ & - & - & - & $2.14 \mathrm{E}-03$ \\
\hline
\end{tabular}


Table 2. (continued).

\begin{tabular}{|c|c|c|c|c|c|c|c|c|c|c|}
\hline \multirow[b]{2}{*}{ Radionuclide } & \multirow[b]{2}{*}{ Half-Life $^{d}$} & \multicolumn{9}{|c|}{ Estimated Emissions $(\mathbf{C i})^{b, c}$} \\
\hline & & $\begin{array}{c}\text { ATR } \\
\text { Complex } \\
\end{array}$ & CFA & CITRC & INTEC & MFC & NRF & RWMC & $\begin{array}{l}\text { TAN/ } \\
\text { SMC }\end{array}$ & Total \\
\hline $\mathrm{Y}-92$ & $3.54 \mathrm{~h}$ & $1.56 \mathrm{E}-12$ & - & - & - & - & - & - & - & $1.56 \mathrm{E}-12$ \\
\hline $\mathrm{Zn}-65$ & $243.9 \mathrm{~d}$ & 1.30E-04 & $2.34 \mathrm{E}-12$ & - & - & - & - & $2.56 \mathrm{E}-16$ & - & $1.30 \mathrm{E}-04$ \\
\hline Zr-95 & $63.98 \mathrm{~d}$ & $6.58 \mathrm{E}-06$ & $1.50 \mathrm{E}-10$ & - & - & 8.44E-12 & - & - & - & $6.58 \mathrm{E}-06$ \\
\hline Zr-97 & $16.9 \mathrm{~h}$ & $1.14 \mathrm{E}-11$ & - & - & - & - & - & - & - & $1.14 \mathrm{E}-11$ \\
\hline Totals & & $1.67 \mathrm{E}+03$ & $9.20 \mathrm{E}-01$ & $1.50 \mathrm{E}-04$ & $1.14 \mathrm{E}+03$ & $2.14 \mathrm{E}-01$ & 7.69E-01 & $8.13 \mathrm{E}+01$ & $3.26 \mathrm{E}-02$ & $2.89 \mathrm{E}+03$ \\
\hline
\end{tabular}

a. Radionuclide release information provided by the INL contractor.

b. One curie $(\mathrm{Ci})=3.7 \times 10^{10}$ becquerels $(\mathrm{Bq})$.

c. Includes only those radionuclides with a total INL Site release that potentially contribute greater than $1 \mathrm{E}-05 \mathrm{mrem}(1 \mathrm{E}-07 \mathrm{mSv}) \mathrm{dose}$.

d. Radionuclide half- lives from FGR-12 (EPA 1993), $\mathrm{d}=$ days, $\mathrm{h}=$ hours, $\mathrm{m}=$ minutes, $\mu \mathrm{s}=$ microseconds, $\mathrm{s}=$ seconds, and $\mathrm{y}=\mathrm{years}$.

e. A long dash signifies the radionuclide was not reported to be released to air from the facility in 2013 . 
Table 3. Radionuclides important in terms of radiological dose based on the 2007 to 2013 NESHAP reports.

\begin{tabular}{cc}
\hline Radionuclide & $\begin{array}{c}\text { Percent of Total Dose } \\
\text { 2007 through 2013 }\end{array}$ \\
\hline H-3 (vapor) & $25.22 \%$ \\
Pu-239/240 & $19.78 \%$ \\
Cs-137 & $18.13 \%$ \\
Sr-90 & $12.49 \%$ \\
Am-241 & $8.20 \%$ \\
Ar-41 (gas) & $7.22 \%$ \\
I-129 & $4.54 \%$ \\
Pu-238 & $1.51 \%$ \\
C-14 & $0.59 \%$ \\
Co-60 & $0.58 \%$ \\
Am-243 & $0.45 \%$ \\
Pu-241 & $0.42 \%$ \\
Kr-88 (gas) & $0.19 \%$ \\
Xe-138 (gas) & $0.18 \%$ \\
Kr-85 (gas) & $0.11 \%$ \\
Kr-87 (gas) & $0.06 \%$ \\
Cm-244 & $0.05 \%$ \\
Cf-252 & $0.04 \%$ \\
Eu-152 & $0.04 \%$ \\
Eu-154 & $0.03 \%$ \\
I-131 & $0.03 \%$ \\
Ni-63 -234 & $0.03 \%$ \\
Total & $0.02 \%$ \\
\hline
\end{tabular}

a. Unless otherwise indicated, radionuclide is assumed to be in a particulate form.

Any atmospheric transport model could be used with the methodology. For this assessment, the CALPUFF Lagrangian puff dispersion model, coupled with 1 year of meteorological data, was used to calculate TICs at sampler locations for a 1-hour release of unit activity $(1 \mathrm{Ci})$ for every hour of the year. Development of the model, including meteorological data, model verification, and validation, is presented in Rood and Sondrup (2014). The unit-activity time-integrated concentration (TICu) values were calculated at all sampler locations for releases from eight INL Site facilities. The TICu values were then scaled and integrated for a given release quantity and release duration. All facilities modeled a ground-level release, emanating either from the center of the facility or at a point where significant emissions are possible. In addition to ground-level releases, three existing stacks at the ATR Complex, INTEC, and MFC were modeled. 
Meteorological data from the 35 stations comprising the INL Site Mesonet network, the Idaho Falls Regional airport, upper air data from the Boise airport, and three-dimensional gridded data from the Weather Research and Forecasting model were used for modeling. Simulations were run using an already available meteorological data set for years 2006, 2007, and 2008, but only data from year 2006 was used in the FD analysis.

A comparison of annual TICu values calculated with CALPUFF and the National Oceanic and Atmospheric Administration MDIFFH model (currently used at INL to assess annual dose) was performed to test the validity of the CALPUFF simulation. In general, the CALPUFF simulation produced results that were comparable to those generated by MDIFFH; differences could be explained by differences in model features and capabilities. The impact of meteorological data sequences was examined by comparing TICu isopleths and dispersion factors at individual sampler locations calculated with CALPUFF for each of the 3 years of meteorological data considered. Consistent results from year to year indicate that a single year of data is adequate for FD evaluation. A validation exercise using Sb-125 annual average concentrations measured at INL sampler locations in 1987 indicated that CALPUFF predicted the measured concentrations more accurately than the model MESODIF (i.e., the precursor to MDIFFH) and provided dispersion estimates that were consistent with the expected uncertainty of atmospheric transport models in complex terrain environments.

The methodology and tool were demonstrated by performing an assessment of the current INL ambient air monitoring network. The release duration of events varied from 1 hour up to 340 hours. Rood and Sondrup (2014) assumed a nominal sampler flow rate of $2 \mathrm{cfm}$ and a sampling time of 168 hours. Detection frequencies were calculated using both BEA requested detection limits and MDA levels as reported by ESER.

Three representative radionuclides identified as key radionuclides in INL's annual NESHAPs evaluations were considered for the FD analysis: Cs-137 (beta-gamma emitter), Pu-239 (alpha emitter), and Sr-90 (beta emitter). Source-specific release quantities were calculated for each radionuclide, such that the maximum inhalation dose at any publicly accessible sampler or the NESHAPs MEI location at Frenchman's Cabin was equivalent to $0.1 \mathrm{mrem} /$ year (i.e., $1 \%$ of the $10-\mathrm{mrem} /$ year standard). Dose calculations were based on a reference individual using dose coefficients from DOE-STD-1196-2011 (2011). Detection frequencies were calculated separately for the onsite and offsite monitoring network. As expected, detection frequencies were generally less for the offsite sampling network compared to the onsite network.

The CALPUFF air dispersion model, FD methodology, and software described and documented in Rood and Sondrup (2014) were used to evaluate a hypothetical sampling network that would meet the performance metrics stated in PSQ \#5 for the radionuclides listed in Table 2. A local-scale model, consisting of a Gaussian plume model and site-specific meteorological data (see Appendix A), was also constructed and used with the FD software to evaluate sampler placement near INL Site facilities. In response to PSQ \#6, the existing INL Site air monitoring network was then evaluated using release characteristics (i.e., release quantities and parameters) determined for the hypothetical network that would satisfy the performance metrics stated in PSQ \#6.

\subsection{Receptor Locations and Exposure Characteristics}

A survey conducted in 2013 by ESER (DOE-ID 2014b) identified 98 potential residences around the INL Site perimeter. Many of the potential residences were close to one another and could be represented by a single point. For this assessment, the 98 residences were reduced to 27 locations where 
potential receptor dose would be evaluated. Figure 5 shows the locations of the 27 potential residential receptors (i.e., yellow-shaded circles) and the locations of the 98 potential residences identified by ESER (i.e., black dots). Coordinates of the 27 potential residential receptors are presented in Table 4.

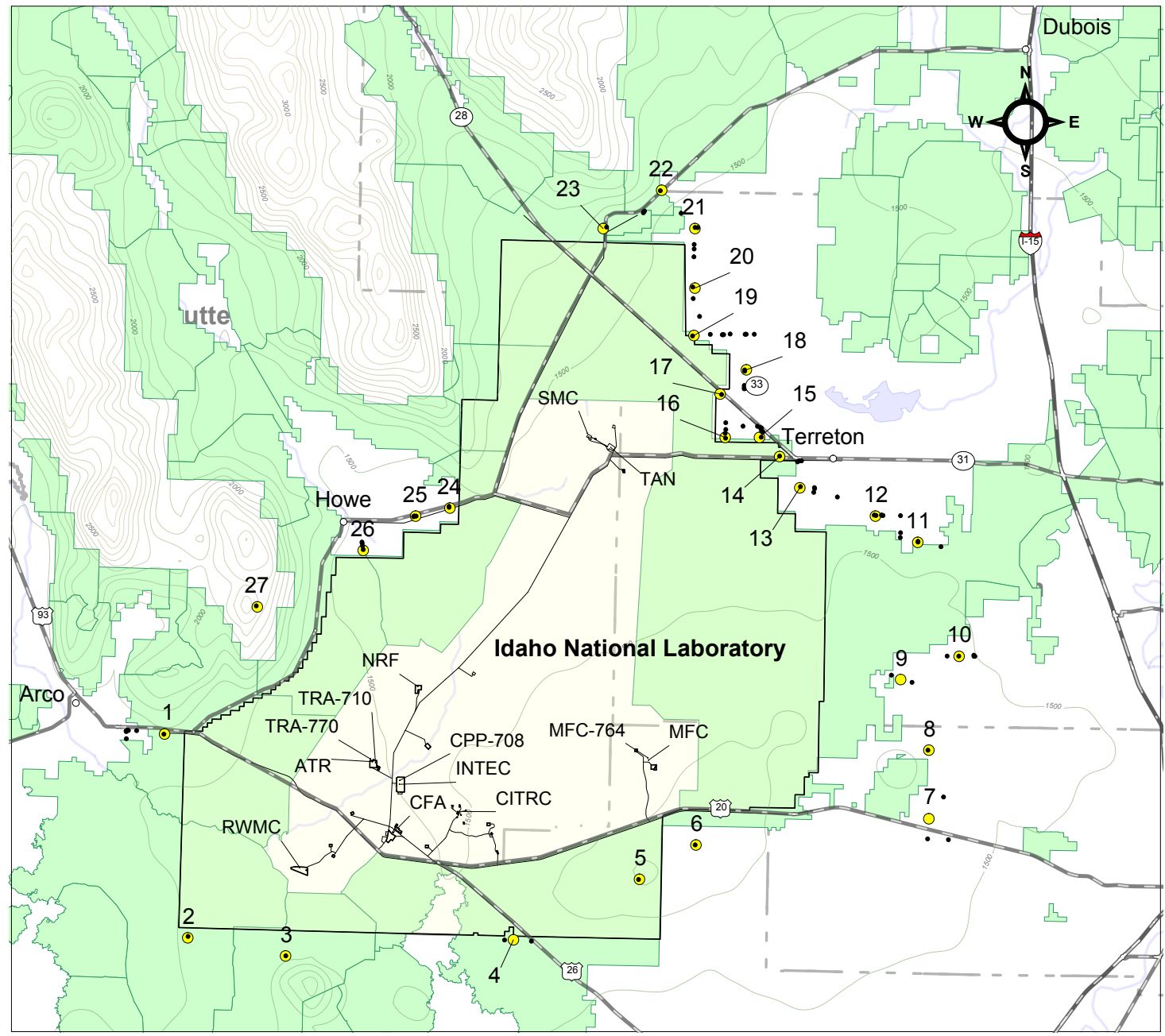

Figure 5. Ninety-eight potential resident receptor locations identified by ESER (i.e., black dots) and the 27 potential resident receptor locations used in the model (i.e., yellow-filled circles that are numbered 1 through 27). Also shown are the grazing allotment boundaries (i.e., green-shaded regions).

Also shown in Figure 5 are the grazing allotments on the INL Site where livestock graze during the summer months. Persons who tend the livestock are not permanent residents but are members of the public; therefore, dose constraints to the public are also applied. For evaluation of the air monitoring network, the dose was evaluated for a person in the grazing allotment boundary nearest to an INL Site source (Table 5). 
Table 4. Universal Transverse Mercator coordinates of the 27 potential resident receptor locations used in the model. These receptors are treated as full-time residents.

\begin{tabular}{|c|c|c|}
\hline Receptor ID & $\begin{array}{c}\text { Universal Transverse Mercator } \\
\text { E Coordinate (m) }\end{array}$ & $\begin{array}{c}\text { Universal Transverse Mercator } \\
\text { N Coordinate (m) }\end{array}$ \\
\hline 1 & 322575 & 4830358 \\
\hline 2 & 324674 & 4811920 \\
\hline 3 & 333528 & 4810277 \\
\hline 4 & 354156 & 4811738 \\
\hline 5 & 365566 & 4817214 \\
\hline 6 & 370677 & 4820318 \\
\hline 7 & 391762 & 4822691 \\
\hline 8 & 391762 & 4828898 \\
\hline 9 & 389206 & 4835287 \\
\hline 10 & 394500 & 4837386 \\
\hline 11 & 390758 & 4847700 \\
\hline 12 & 386924 & 4850074 \\
\hline 13 & 380078 & 4852629 \\
\hline 14 & 378253 & 4855459 \\
\hline 15 & 376427 & 4857193 \\
\hline 16 & 373324 & 4857193 \\
\hline 17 & 372868 & 4861118 \\
\hline 18 & 375241 & 4863309 \\
\hline 19 & 370494 & 4866412 \\
\hline 20 & 370586 & 4870702 \\
\hline 21 & 370586 & 4876087 \\
\hline 22 & 367574 & 4879556 \\
\hline 23 & 362280 & 4876087 \\
\hline 24 & 348406 & 4850804 \\
\hline 25 & 345302 & 4850074 \\
\hline 26 & 340556 & 4846970 \\
\hline 27 & 330972 & 4841859 \\
\hline
\end{tabular}

The 27 potential resident receptor locations surrounding the INL Site are treated as full-time residents; therefore, the exposure scenario used for the representative individual dose calculation as described in Appendix B of the ASER (DOE-ID 2014b) was used to derive an all-pathway dose coefficient (APDC). The APDC is calculated using a unit dose factor ( $\mathrm{mrem} /$ year per $\mathrm{pCi} / \mathrm{m}^{3}$ ), and an annual breathing rate $\left(\mathrm{m}^{3} /\right.$ year).

$A P D C=\frac{U D}{B R}$

where

$U D=$ the unit dose factor derived from the ASER report (mrem/year per $\left.\mathrm{pCi} / \mathrm{m}^{3}\right)$ 
$B R=$ annual breathing rate for the reference individual $\left(8033 \mathrm{~m}^{3} /\right.$ year $)$.

Unit dose factors and APDCs were derived using the 2013 ASER report (DOE-ID 2014b) for releases from ATR. Because doses are normalized to the air concentration, the APDCs are independent of source location, source strength, and dispersion conditions; therefore, they only reflect the parameters of the dose calculation.

For the grazing allotment receptor, inhalation was the only exposure pathway considered because these persons are not residents but transient members of the public. The breathing rate used in all dose calculations $\left(8,033 \mathrm{~m}^{3} /\right.$ year $)$ is the breathing rate used for the reference individual dose calculation in the ASER report (DOE-ID 2014b). APDCs and inhalation dose coefficient from DOE-STD-1196-2011 (2011) are presented in Table 6.

Table 5. Distance from each INL facility to the nearest grazing allotment boundary. These receptors are treated as part-time residents.

\begin{tabular}{lcc}
\hline \multicolumn{1}{c}{ Facility } & Distance $(\mathbf{m})$ & Approximate Direction \\
\hline MFC-774 and MFC-764 & 3,800 & $\mathrm{NNE}$ \\
RWMC & 1,500 & $\mathrm{SW}$ \\
ATR and TRA-770 & 5,100 & $\mathrm{NW}$ \\
CPP-1777 and CPP-708 & 6,400 & $\mathrm{SSW}$ \\
NRF & 3,500 & $\mathrm{NE}$ \\
CFA-625 & 2,000 & $\mathrm{SW}$ \\
CITRC & 4,800 & $\mathrm{SSW}$ \\
TAN-625 & 3,400 & $\mathrm{~N}$ \\
\hline
\end{tabular}

For the shepherd or rancher grazing livestock, only inhalation is considered because this person would not grow crops or consume meat and milk from the livestock while working grazing allotment. Therefore, inhalation dose coefficients for a reference individual as given in DOE-STD-1196-2011 (2011) were used. The most conservative dose coefficients were used in this case; values for radionuclides of interest are presented in Table 6.

Table 6. Unit doses, APDCs, and inhalation dose coefficients from DOE-STD-1196-2011 (2011) for the important radionuclides at the INL Site. All dose coefficients are for effective dose.

\begin{tabular}{|c|c|c|c|}
\hline Radionuclide $^{a}$ & $\begin{array}{c}\text { Unit Dose }^{\mathrm{b}}(\mathrm{mrem} / \text { year } \\
\left.\text { per } \mathrm{pCi} / \mathrm{m}^{3}\right)\end{array}$ & $\operatorname{APDC}^{\mathrm{c}}(\mathrm{mrem} / \mathbf{p C i})$ & $\begin{array}{c}\text { Inhalation Dose } \\
\text { Coefficient }^{\mathrm{d}}(\mathrm{mrem} / \mathrm{pCi})\end{array}$ \\
\hline Am-241 & $3.01 \mathrm{E}+03$ & $3.74 \mathrm{E}-01$ & $3.63 \mathrm{E}-01$ \\
\hline Cs-137 & $3.44 \mathrm{E}+01$ & $4.29 \mathrm{E}-03$ & $8.21 \mathrm{E}-05$ \\
\hline $\mathrm{H}-3\left(\mathrm{HTO}^{\mathrm{d}}\right)$ & $7.14 \mathrm{E}-03$ & 8.89E-07 & 7.14E-08 \\
\hline I-131 (vapor) & $1.35 \mathrm{E}+01$ & $1.68 \mathrm{E}-03$ & $9.66 \mathrm{E}-05$ \\
\hline $\mathrm{Pu}-238$ & $3.37 \mathrm{E}+03$ & $4.20 \mathrm{E}-01$ & 4.07E-01 \\
\hline $\mathrm{Pu}-239$ & $3.71 \mathrm{E}+03$ & 4.62E-01 & $4.48 \mathrm{E}-01$ \\
\hline Sr-90 & $9.00 \mathrm{E}+01$ & $1.12 \mathrm{E}-02$ & $6.07 \mathrm{E}-04$ \\
\hline
\end{tabular}

a. Unless otherwise indicated, radionuclide is in a particulate form.

b. Unit dose coefficients from 2013 ASER (DOE-ID 2014b).

c. APDC equation from Section 4.4.

d. DOE-STD-1196-2011 (2011). HTO is tritiated water vapor. 


\subsection{Relevant Release Quantities}

The relevant release quantity is the quantity released from an INL Site facility that results in a stated effective dose limit not being exceeded. Thus, the relevant release quantity is different for each INL Site facility and each radionuclide. 40 CFR Part 61, Subpart H (2010) states "emissions of radionuclides to ambient air from U.S. Department of Energy facilities shall not exceed those amounts that would cause any member of the public to receive in any year an effective dose equivalent exceeding $10 \mathrm{mrem} / \mathrm{yr}$." To meet the requirement for monitoring only, "radionuclide releases that would result in an effective dose of $10 \%$ of the standard shall be readily detectable and distinguishable from background." Therefore, radionuclide concentrations at the receptor locations that would result in $1 \mathrm{mrem} /$ year would need to be readily detectable and distinguishable from background.

Using the model described in Rood and Sondrup (2014), radionuclide release rates from each facility that would result in a dose of $1 \mathrm{mrem} /$ year were calculated. However, sampler filters are collected once per week (i.e., 168 hours); therefore, they do not accumulate activity throughout the year. A distribution of weekly predicted concentrations from each facility, for each radionuclide, and each potential residential receptor was obtained for the period of 1 year (i.e., 52 values) for an arbitrary release rate. From this distribution, the maximum 168-hour average concentration for each facility and radionuclide was extracted and the release quantity from the facility was scaled such that the maximum all-pathway dose (calculated using the APDCs from Table 6) during the 1-week period did not exceed $1 \mathrm{mrem} / 52$ weeks $=0.0192 \mathrm{mrem} /$ week (Table 7). This procedure results in the minimum amount of activity released during a week that would produce a weekly dose rate that, if continuous over a year, would result in a dose of 1 mrem. Thus, if the samplers are able to detect these quantities, they would also be able to detect any larger quantities. In general, these release quantities are 1.5 to over 100 times the 2013 NESHAP annual releases.

A similar procedure was applied for the shepherd or rancher grazing livestock at INL. Because the person is not a resident but is transitory, release quantities were determined such that the maximum inhalation dose of $1 \mathrm{mrem}$ in a 24 -hour period would not be exceeded (Table 8 ). Thus, the inhalation dose coefficients from Table 6 were used to calculate release quantities instead of the ASER-derived APDCs. If a significant release did occur at INL, such that a 1-mrem dose would be incurred, the person's grazing livestock on INL property could be removed prior to their dose limit being exceeded based on the measurement data.

Source location and release parameters for INL Site facilities that were included in the assessment are provided in Tables 9 and 10. For each major INL Site facility, a ground-level release was modeled that emanated either from a building where most of the radioactive material is stored or emitted or from the geographic center of the facility. In addition to a ground-level release from each facility, three existing stacks at the ATR Complex, INTEC, and MFC facilities were modeled.

Tritium for both receptor scenarios is treated differently because it involves sampling for vapor instead of particulates. Moreover, tritium is only released in significant quantities from three facilities: ATR Complex, INTEC, and RWMC. For these reasons, tritium was only evaluated for these three facilities. Tritium release quantities and a description of the tritium samplers are provided in Appendix B. 
Table 7. Release quantities (pCi) that would result in a maximum weekly dose of $0.0192 \mathrm{mrem}$ (equivalent to $1 \mathrm{mrem} /$ year if continuous over a year).

\begin{tabular}{lccccccc}
\multicolumn{1}{c}{ Facility } & Am-241 & Cs-137 & H-3 & I-131 & Pu-238 & Pu-239 & Sr-90 \\
\hline ATR & $1.17 \mathrm{E}+09$ & $1.02 \mathrm{E}+11$ & & $2.62 \mathrm{E}+11$ & $1.05 \mathrm{E}+09$ & $9.51 \mathrm{E}+08$ & $3.92 \mathrm{E}+10$ \\
CFA-625 & $6.39 \mathrm{E}+08$ & $5.57 \mathrm{E}+10$ & & $1.42 \mathrm{E}+11$ & $5.69 \mathrm{E}+08$ & $5.17 \mathrm{E}+08$ & $2.13 \mathrm{E}+10$ \\
CITRC & $7.05 \mathrm{E}+08$ & $6.15 \mathrm{E}+10$ & & $1.57 \mathrm{E}+11$ & $6.28 \mathrm{E}+08$ & $5.71 \mathrm{E}+08$ & $2.36 \mathrm{E}+10$ \\
CPP-1774 & $1.02 \mathrm{E}+09$ & $8.93 \mathrm{E}+10$ & \multirow{2}{*}{$4.31 \mathrm{E}+14$} & $2.28 \mathrm{E}+11$ & $9.12 \mathrm{E}+08$ & $8.29 \mathrm{E}+08$ & $3.42 \mathrm{E}+10$ \\
CPP-708 & $9.58 \mathrm{E}+08$ & $8.36 \mathrm{E}+10$ & & $2.13 \mathrm{E}+11$ & $8.53 \mathrm{E}+08$ & $7.76 \mathrm{E}+08$ & $3.20 \mathrm{E}+10$ \\
MFC-764 & $3.23 \mathrm{E}+09$ & $2.81 \mathrm{E}+11$ & & $7.19 \mathrm{E}+11$ & $2.88 \mathrm{E}+09$ & $2.61 \mathrm{E}+09$ & $1.08 \mathrm{E}+11$ \\
MFC-774 & $3.18 \mathrm{E}+08$ & $2.77 \mathrm{E}+10$ & & $7.07 \mathrm{E}+10$ & $2.83 \mathrm{E}+08$ & $2.57 \mathrm{E}+08$ & $1.06 \mathrm{E}+10$ \\
NRF & $1.68 \mathrm{E}+09$ & $1.47 \mathrm{E}+11$ & & $3.74 \mathrm{E}+11$ & $1.50 \mathrm{E}+09$ & $1.36 \mathrm{E}+09$ & $5.61 \mathrm{E}+10$ \\
RWMC & $4.29 \mathrm{E}+08$ & $3.74 \mathrm{E}+10$ & \multirow{2}{*}{$1.81 \mathrm{E}+14$} & $9.56 \mathrm{E}+10$ & $3.82 \mathrm{E}+08$ & $3.48 \mathrm{E}+08$ & $1.43 \mathrm{E}+10$ \\
TAN-679 & $5.99 \mathrm{E}+08$ & $5.22 \mathrm{E}+10$ & & $1.33 \mathrm{E}+11$ & $5.33 \mathrm{E}+08$ & $4.85 \mathrm{E}+08$ & $2.00 \mathrm{E}+10$ \\
TRA-770 & $7.96 \mathrm{E}+08$ & $6.94 \mathrm{E}+10$ & \multirow{2}{*}{$3.35 \mathrm{E}+14$} & $1.77 \mathrm{E}+11$ & $7.09 \mathrm{E}+08$ & $6.45 \mathrm{E}+08$ & $2.66 \mathrm{E}+10$ \\
\hline
\end{tabular}

Table 8. Release quantities (pCi) that would result in a maximum 24-hour dose of 1.0 mrem at the nearest distance to a grazing allotment from an INL Site facility.

\begin{tabular}{lccccccc}
\hline \multicolumn{1}{c}{ Facility } & Am-241 & Cs-137 & H-3 & I-131 & Pu-238 & Pu-239 & Sr-90 \\
\hline ATR & $3.99 \mathrm{E}+09$ & $9.410 \mathrm{E}+12$ & & $1.50 \mathrm{E}+13$ & $3.56 \mathrm{E}+09$ & $3.23 \mathrm{E}+09$ & $2.39 \mathrm{E}+12$ \\
CFA-625 & $1.43 \mathrm{E}+09$ & $3.378 \mathrm{E}+12$ & & $5.39 \mathrm{E}+12$ & $1.28 \mathrm{E}+09$ & $1.16 \mathrm{E}+09$ & $8.57 \mathrm{E}+11$ \\
CITRC & $3.74 \mathrm{E}+09$ & $8.802 \mathrm{E}+12$ & & $1.40 \mathrm{E}+13$ & $3.33 \mathrm{E}+09$ & $3.03 \mathrm{E}+09$ & $2.23 \mathrm{E}+12$ \\
CPP-1774 & $5.17 \mathrm{E}+09$ & $1.218 \mathrm{E}+13$ & $2.63 \mathrm{E}+16$ & $1.94 \mathrm{E}+13$ & $4.61 \mathrm{E}+09$ & $4.19 \mathrm{E}+09$ & $3.09 \mathrm{E}+12$ \\
CPP-708 & $1.18 \mathrm{E}+10$ & $2.784 \mathrm{E}+13$ & & $4.44 \mathrm{E}+13$ & $1.05 \mathrm{E}+10$ & $9.57 \mathrm{E}+09$ & $7.07 \mathrm{E}+12$ \\
MFC-764 & $4.08 \mathrm{E}+09$ & $9.628 \mathrm{E}+12$ & & $1.54 \mathrm{E}+13$ & $3.64 \mathrm{E}+09$ & $3.31 \mathrm{E}+09$ & $2.44 \mathrm{E}+12$ \\
MFC-774 & $2.44 \mathrm{E}+09$ & $5.742 \mathrm{E}+12$ & & $9.15 \mathrm{E}+12$ & $2.17 \mathrm{E}+09$ & $1.97 \mathrm{E}+09$ & $1.46 \mathrm{E}+12$ \\
NRF & $3.63 \mathrm{E}+09$ & $8.551 \mathrm{E}+12$ & & $1.36 \mathrm{E}+13$ & $3.24 \mathrm{E}+09$ & $2.94 \mathrm{E}+09$ & $2.17 \mathrm{E}+12$ \\
RWMC & $8.88 \mathrm{E}+08$ & $2.094 \mathrm{E}+12$ & $4.52 \mathrm{E}+15$ & $3.34 \mathrm{E}+12$ & $7.92 \mathrm{E}+08$ & $7.20 \mathrm{E}+08$ & $5.31 \mathrm{E}+11$ \\
TAN-679 & $1.50 \mathrm{E}+09$ & $3.545 \mathrm{E}+12$ & & $5.65 \mathrm{E}+12$ & $1.34 \mathrm{E}+09$ & $1.22 \mathrm{E}+09$ & $9.00 \mathrm{E}+11$ \\
TRA-770 & $9.93 \mathrm{E}+09$ & $2.340 \mathrm{E}+13$ & $5.05 \mathrm{E}+16$ & $3.73 \mathrm{E}+13$ & $8.86 \mathrm{E}+09$ & $8.04 \mathrm{E}+09$ & $5.94 \mathrm{E}+12$ \\
\hline
\end{tabular}


Table 9. Description of modeled sources and locations that were considered in the assessment.

\begin{tabular}{|c|c|c|c|c|c|}
\hline Facility & Source & $\begin{array}{l}\text { Release } \\
\text { Type }\end{array}$ & Source Description & $\begin{array}{l}\text { Easting }^{\mathrm{a}} \\
(\mathrm{m})\end{array}$ & $\begin{array}{l}\text { Northing }^{\mathrm{a}} \\
(\mathrm{m})\end{array}$ \\
\hline ATR Complex & TRA-770 & Stack & ATR Stack & 341206 & 4828106 \\
\hline INTEC & CPP-708 & Stack & INTEC Main Stack & 343862 & 4826156 \\
\hline MFC & MFC-764 & Stack & Experimental Breeder Reactor-II Main Stack & 366326 & 4828209 \\
\hline ATR Complex & Center & Ground & Near center of ATR Complex & 341401 & 4827855 \\
\hline CFA & CFA-625 & Ground & Lab fume hoods (near center of CFA) & 343271 & 4821432 \\
\hline CITRC & PBF-632 & Ground & $\begin{array}{c}\text { Waste Reduction Operations Complex } \\
\text { Support Building Vent }\end{array}$ & 349099 & 4823351 \\
\hline INTEC & СРP-1774 & Ground & $\begin{array}{l}\text { Three Mile Island-2 Spent Fuel Storage } \\
\text { Installation (near center of INTEC) }\end{array}$ & 343831 & 4825808 \\
\hline MFC & MFC-774 & Ground & $\begin{array}{l}\text { Zero Power Physics Reactor Support Wing } \\
\text { (south center of MFC) }\end{array}$ & 366389 & 4828004 \\
\hline NRF & Center & Ground & Near center of NRF & 345498 & 4834667 \\
\hline RWMC & Center & Ground & Near center of RWMC & 334818 & 4818274 \\
\hline SMC/TAN & TAN-679 & Ground & SMC Manufacturing and Assembly Building & 360856 & 4857565 \\
\hline
\end{tabular}

a. UTM coordinate system.

Table 10. Stack release parameters.

\begin{tabular}{lccccc}
\hline \multicolumn{1}{c}{ Facility } & Source Stack & $\begin{array}{c}\text { Stack Height } \\
(\mathbf{m})\end{array}$ & $\begin{array}{c}\text { Exit Diameter } \\
(\mathbf{m})\end{array}$ & $\begin{array}{c}\text { Exit Velocity }^{\text {a }} \\
\left(\mathbf{m ~ s}^{\mathbf{1}} \mathbf{)}\right.\end{array}$ & $\begin{array}{c}\text { Flow Rate }^{\text {a }} \\
(\mathbf{c f m})\end{array}$ \\
\hline ATR Complex & TRA-770 & 76.2 & 1.524 & 10.03 & 38,776 \\
INTEC & CPP-708 & 76.2 & 1.83 & 10.65 & 59,370 \\
MFC & MFC-764 & 60 & 1.524 & 9.081 & 35,100 \\
\hline
\end{tabular}

a. Flow rates and exit velocities based on average 2013 values.

\subsection{Adequate Monitoring Program}

The approach used in the Environmental Monitoring Plan will meet the guidance of the DOE Handbook (DOE 2015) and will meet policy and guidance requirements established for INL Site air emissions.

Those radionuclides released from the facility (Table 9) that are major contributors to the effective dose equivalent must be collected and measured as part of the environmental measurement program at a minimum detectable amount that meets the concentrations specified in Table 2 (40 CFR Part 61, Appendix E).

Radionuclide concentrations that would cause an effective dose equivalent of $10 \%$ of the standard shall be readily detectable and distinguishable from background.

\subsection{Existing Idaho National Laboratory Ambient Air Monitoring Network}

Monitoring locations and procedures can be found in project-specific documents. Current particulate monitoring locations are illustrated in Figure 6. Monitors include those operated by BEA and ESER. Tritium is monitored in Idaho Falls (ESER-IDA), Blackfoot (BEA-BLKFT), the Experimental Field Station (BEA-EFS), and Atomic City (ESER-ATO). 


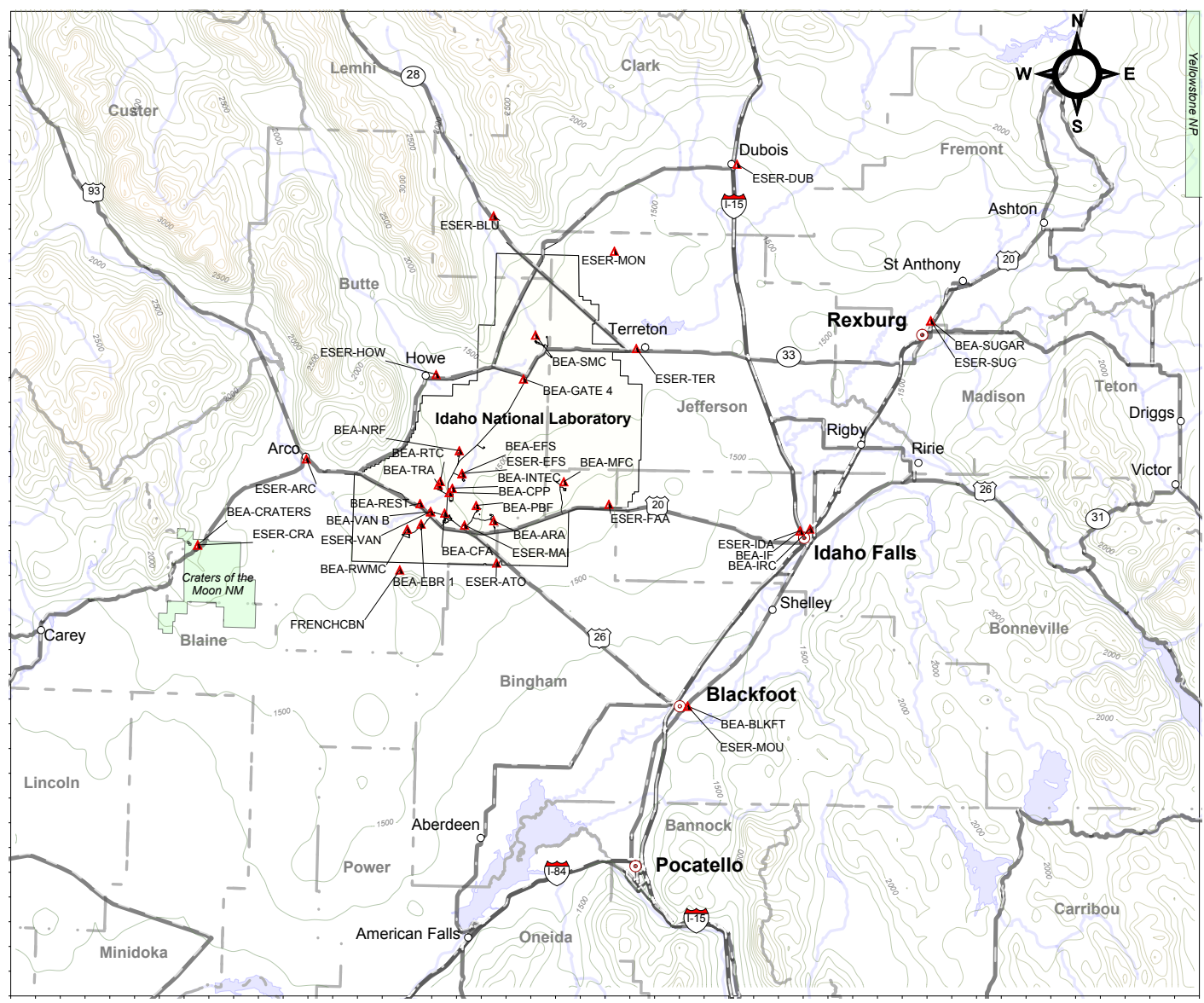

Figure 6. Atmospheric dispersion modeling domain showing all INL air monitoring locations. Stations with the BEA prefix are operated by BEA. Likewise, stations with the ESER prefix are operated by ESER. The station identified as FRENCHMAN (south of the INL southern boundary) is not a station, but the location of the MEI for most calendar years.

\section{DATA QUALITY OBJECTIVE STEP 4-DEFINE THE BOUNDARIES}

The primary objective of DQO Step 4 is to identify and specify the spatial and temporal boundaries pertinent for decision-making and identify practical constraints associated with sample/data collection.

\subsection{Modeling Boundaries}

To appropriately locate environmental sampling stations for airborne radionuclides, it is necessary to understand the long-term transport of radioactive effluents from the INL Site to potential receptor locations. Atmospheric transport has been extensively studied at INL and numerous models, ranging from the straight-line Gaussian plume model to more complex Lagrangian puff models, have been used to model atmospheric transport at INL. However, Lagrangian puff models are deemed more appropriate for this type of modeling because the modeling domain (as illustrated in Figure 6) represents a large region, measuring $200 \mathrm{~km} \times 240 \mathrm{~km}$. At distances beyond 50-km, EPA recommends use of the CALPUFF Lagrangian puff model instead of the steady-state models like the Gaussian Plume model and AERMOD for atmospheric transport calculations. For these calculations, the CALPUFF model was used for all atmospheric transport calculations, except in the case of evaluation of hypothetical sampler locations less than $10 \mathrm{~km}$ from an INL source. In these cases, a Gaussian Plume model was implemented (Appendix A). 
A complete discussion of the atmospheric transport model selection criteria, annual and seasonal average dispersion factors, model verification, and model validation is presented in Rood and Sondrup (2014).

\subsection{Spatial Boundaries}

The spatial boundary is defined by the region represented by the air surveillance network. The locations of the samplers within the monitoring network also dictate the spatial boundaries the data will represent. The spatial boundaries of the analysis are provided in Figure 6.

\subsection{Temporal Boundaries and Resolution}

The set of temporal boundaries is the yearly dose to the MEI.

\subsection{Practical Constraints}

To identify the most effective sites for environmental sampling of radioactive air emissions, it is desirable to place the station near a location where the expected radionuclide air concentrations are high enough to be detectable. Other constraints exist and include the following:

- Availability of space to house the station

- Availability of power

- Accessibility for sample retrieval

- Existence of structures or vegetation between the source and sample station that might perturb transport of airborne radionuclides

- Vulnerability to vandalism or other damage (by water, automobiles, etc.)

- Vulnerability to external factors, such as dust generated by traffic that could reduce sampler efficiency.

\section{DATA QUALITY OBJECTIVE STEP 5-DEVELOP DECISION RULES}

Chapter 6 of the DQO report provides answers to the PSQs in Chapter 3. The decisions are based on assumptions and the data inputs listed in Chapter 4.

\subsection{Decision \#1}

Question \#1: What radionuclides of concern are expected in the air effluent stream on the INL Site?

Action \#1. Use the available isotope information from the most recent NESHAPS report to establish a list of radionuclides of concern and their particular form.

Using the 2007 to 2013 NESHAP reports, the radionuclides that contribute the most to total dose over the 7-year period are summarized in Table 3 .

Decision \#1: The radionuclides of concern are listed in Table 3.

\subsection{Decision \#2}

Question \#2: What are the potential emission sources for radiological air emissions on the INL Site and which are most critical for addressing the study question?

Action \#2. Determine which INL Site emission units generate the greatest offsite impacts, based on qualitative or, if needed, quantitative criteria. 
As discussed in Section 4.1, major emission sources include RWMC (vents), TRA (stack, vent, and fugitive releases), INTEC (stack, vent, and fugitive releases), NRF (vent), CFA (vent), CITRIC (vent), MFC (stack and vent), TAN/SMC (vent) and minor emission sources include various ponds and Comprehensive Environmental Response, Compensation, and Liability Act sites.

Decision \#2. Potential emission sources are listed in Section 4.1.

\subsection{Decision \#3}

\section{Question \#3: What radionuclide release rates are routinely expected from the INL Site emission unit(s) of interest?}

Action \#3. Determine radionuclide release rates that are routinely expected from INL Site facilities and release quantities that would result in dose limits being approached at an MEI.

Radionuclides routinely emitted from INL facilities are presented in Table 2. Table 3 presents radionuclides routinely emitted from INL facilities that are important in terms of dose based on annual NESHAPS report. Radionuclides that contribute to more than $1 \%$ of the total dose were identified as important and used in the analysis. Radionuclide release quantities for these important radionuclides that equate to a weekly dose of $0.0192 \mathrm{mrem}$ ( $1 \mathrm{mrem} /$ year for a year) to the offsite resident are presented in Table 7. Table 8 presents the release quantities for important radionuclides that equate to a 1 -mrem dose to a shepherd/rancher on an INL grazing allotment during a 24-hour period. The FD methodology described in Rood and Sondrup (2014) does not have the limitation that releases have to be chronic and continuous over the period of a year. Thus, release quantities as presented in Tables 7 and 8 and are proportional to the accumulated dose for a given release time.

Decision \#3. Relevant release quantities are discussed in Section 4 and are based on the dose incurred during a 1-week period for a resident scenario or a 24 -hour period for the shepherd/rancher scenario.

\subsection{Decision \#4}

Question \#4: Where do models predict the location of maximum impact for the reference residents for each INL Site emission source of interest (see Question \#2)?

Action \#4: Apply an appropriate atmospheric dispersion model to determine the receptor locations with maximum impact.

Using the atmospheric transport models described in Section 4.3 and the potential receptors and exposure scenario given in Section 4.4, the location of the MEI for the resident receptor and shepherd-rancher (i.e., grazing allotment) scenarios were determined. The locations of the MEIs are presented in Table 11 for the reference resident and Table 12 for the shepherd-rancher receptor. For the shepherd-rancher receptor, a hypothetical network of receptors were placed in a circle having a radius equal to the minimum distance to the nearest grazing allotment and centered on the facility (see Table 5). Sixteen receptors spaced 22.5 degrees apart were situated along the circle. The MEI was the location with the highest dose resulting from a release from the given facility. Note that the distance and azimuths listed in Table 12 do not necessarily correspond to a location within the grazing boundary. This procedure results in a conservative estimate of the minimum release quantity required to produce a 1-mrem dose, in addition to providing insight into the optimum locations to place samplers. 
Table 11. Location of reference resident for a 168-hour release (1-week) that results in $0.0192 \mathrm{mrem}$ (1.0 mrem/year). See Figure 5 for a map of reference resident locations.

\begin{tabular}{cc}
\hline Facility & $\begin{array}{c}\text { Reference Resident } \\
\text { Location Number }\end{array}$ \\
\hline ATR & 3 \\
CFA-625 & 3 \\
CITRC & 4 \\
CPP-1774 & 3 \\
CPP-708 & 3 \\
MFC-764 & 5 \\
MFC-774 & 6 \\
NRF & 24 \\
RWMC & 3 \\
TAN-679 & 17 \\
TRA-770 & 3 \\
\hline
\end{tabular}

Table 12. Azimuth and distance location of the reference resident location for a 24-hour release (1-day) that results in $1 \mathrm{mrem}$.

\begin{tabular}{ccc}
\hline Facility & Distance from Facility $(\mathbf{m})$ & Azimuth (degrees) \\
\hline ATR & 1,500 & 67.5 \\
CFA-625 & 2,000 & 67.5 \\
CITRC & 4,800 & 67.5 \\
CPP-1774 & 6,400 & 67.5 \\
CPP-708 & 6,400 & 22.5 \\
MFC-764 & 3,800 & 270 \\
MFC-774 & 3,800 & 270 \\
NRF & 3,500 & 180 \\
RWMC & 1,500 & 90 \\
TAN-679 & 3,400 & 180 \\
TRA-770 & 1,500 & 22.5 \\
\hline
\end{tabular}

Decision \#4: The MEI locations for the resident and shepherd-rancher scenario were determined.

\subsection{Decision \#5}

Question \#5: What are the DOE Handbook (DOE 2015) requirements for an adequate radioactive air monitoring program? What are the performance metrics of an adequate air monitoring network? What are the parameters (e.g., number of and placement of monitors, etc.) of an adequate sampling network?

Action \#5: Develop an air monitoring program while considering applicable regulatory requirements, equipment/sampling specifications, and optimal locations. Establish performance metrics for the network and quantitatively evaluate network performance using a site-applied atmospheric transport model coupled with FD methods. 
Decision \#5. The requirements for an air monitoring program for radionuclides are documented in the DOE Handbook (DOE 2015). This guidance establishes the analytical and quality assurance requirements that are applied to air monitoring networks. Documentation that the current INL air monitoring network meets the analytical and quality assurance requirements is provided in DOE (2014a). What remains to be determined are the performance metrics and the number and placement of samplers.

In this analysis, performance metrics for the network are defined in terms of the network's ability to assure that the dose standard is adhered to. As stated in DOE (2015), radionuclide concentrations that would cause an effective dose of $10 \%$ of the $10 \mathrm{mrem} /$ year effective dose standard (i.e., $1 \mathrm{mrem} /$ year) shall be readily detectable and distinguishable from background. The resident and shepherd/rancher scenarios discussed in Section 4.4 used to evaluate the dose to members of the public and release quantities that would result in $1 \mathrm{mrem} /$ year to these receptors were determined and presented in Section 4.5. The shepherd/rancher does not reside year-round and moves within the permitted grazing allotment. To address aforementioned dose standards, the following performance objectives are established for the network:

A. A network FD of $95 \%$ or greater for a 1-week sampling time that results in a maximum dose of 0.019 mrem (or $1 \mathrm{mrem} /$ year if continuous over a year) at a resident receptor location.

B. A network FD of $95 \%$ or greater for a 1 mrem dose from a $24-\mathrm{hr}$ release at the nearest distance to an INL grazing allotment.

The radionuclides used to assess performance objectives are stated in Section 4. Objective A is applicable to the reference residence locations. Objective B is applicable to the shepherd/rancher scenario. The model used nominal values of sampler parameters that include a flow rate of $2 \mathrm{cfm}$ $\left(3.368 \mathrm{~m}^{3} /\right.$ hour$)$, a sampling time of 1 -week, and MDA values that are requested by ESER and routinely achieved by BEA for particulate releases. For tritium releases, a flow rate of $0.019 \mathrm{~m}^{3} /$ hour, a sampling time of 648 hours, and the ESER MDA was used (see Appendix B for details on tritium monitoring).

Table 13 presents the MDA values, the TIC that yields a dose of $0.0192 \mathrm{mrem} / \mathrm{year}$ or $1.0 \mathrm{mrem}$ in a 24-hr period, and the activity accumulated on the filter for the TIC. The activity accumulated on the filter is the TIC value times the sampler flow rate. It is important to note that the sampler MDAs are more than adequate to detect the specified dose limits. Therefore, if a release goes undetected, then it is related to sampler placement and not sampler performance.

The FD analysis for Objective A assumed a sampler was placed at each of the resident receptor locations provided in Table 4 . The release quantity for each radionuclide that resulted in a maximum 1-week dose of $0.0192 \mathrm{mrem}$ ( $1 \mathrm{mrem} /$ year if continuous over the year) was computed (Table 9) and the FD calculated for the network of 27 samplers. In addition to the FD, the network intensity was calculated. Network intensity is the number of samplers with positive detections divided by the total number of samplers. The results for the hypothetical network of samplers at the resident receptor locations are presented in Table 14. Performance objectives were not met for all actinides releases and for Cs-137 released from the CPP-708 stack (i.e., FD values were less than $95 \%$ for the actinides and Cs-137 released from the CPP-708 stack). However, for I-131 and H-3, 100\% detection frequency was achieved. As shown in Table 13, the samplers are more than capable of detecting activity in air that would result in $0.0192 \mathrm{mrem}$. These results were interpreted to mean that a release having the potential to result in a dose of $0.0192 \mathrm{mrem}$ at a potential receptor may go undetected (assuming the hypothetical network of samplers are in place) because of sampler placement. Thus, placing a sampler at each of the 27 locations is not only impractical; it is also ineffective in terms of detecting releases. Samplers would have to be placed in optimum locations closer to sources to improve FD and meet the performance objectives of the network. 
Table 13. Radionuclide MDA, TIC values that yield dose limits, and activity accumulated on filters for the given TIC.

\begin{tabular}{|c|c|c|c|c|c|}
\hline Radionuclide & $\begin{array}{c}\text { MDA } \\
\text { (pCi) }\end{array}$ & $\begin{array}{c}\text { TIC for } \\
0.0192 \mathrm{mrem} / \text { year } \\
\left(\mathrm{pCi}-\mathrm{hr} / \mathrm{m}^{3}\right)^{\mathrm{a}}\end{array}$ & $\begin{array}{c}\text { Activity } \\
\text { Accumulated on } \\
\text { Filter (pCi) }\end{array}$ & $\begin{array}{c}\text { TIC for } \\
1.0 \text { mrem/year } \\
\left(\mathrm{pCi}-\mathrm{hr} / \mathrm{m}^{3}\right)^{\mathbf{b}}\end{array}$ & $\begin{array}{c}\text { Activity } \\
\text { Accumulated on } \\
\text { Filter (pCi) }\end{array}$ \\
\hline Am-241 & 0.029 & $5.60 \mathrm{E}-02$ & 0.188 & $3.01 \mathrm{E}+00$ & 10.1 \\
\hline Cs-137 & 0.700 & $4.88 \mathrm{E}+00$ & 16.4 & $1.33 \mathrm{E}+04$ & 44,727 \\
\hline $\mathrm{H}-3^{\mathrm{c}}$ & 0.752 & $2.36 \mathrm{E}+04$ & 448 & $1.53 \mathrm{E}+07$ & 290,130 \\
\hline I-131 & 0.189 & $1.25 \mathrm{E}+01$ & 42.0 & $1.13 \mathrm{E}+04$ & 38,025 \\
\hline $\mathrm{Pu}-238$ & 0.022 & 4.99E-02 & 0.168 & $2.68 \mathrm{E}+00$ & 9.03 \\
\hline $\mathrm{Pu}-239$ & 0.022 & 4.53E-02 & 0.153 & $2.43 \mathrm{E}+00$ & 8.19 \\
\hline Sr-90 & 0.215 & $1.87 \mathrm{E}+00$ & 6.29 & $1.80 \mathrm{E}+03$ & 6,049 \\
\hline
\end{tabular}

a. The dose that corresponds to this TIC is calculated using the APDCs,

b. The dose that corresponds to this TIC is calculated using the inhalation dose coefficients only.

c. In the case of tritium, the activity is accumulated in atmospheric moisture.

Table 14. Objective A network FD and intensity for a hypothetical sampling network consisting of samplers at each of the 27 resident locations.

\begin{tabular}{|c|c|c|c|c|c|c|c|}
\hline \multirow[b]{2}{*}{ Facility } & \multicolumn{7}{|c|}{ Network FD } \\
\hline & Am-241 & Cs-137 & Pu-238 & Pu-239 & Sr-90 & I-131 & H-3 \\
\hline ATR & $87.93 \%$ & $100.00 \%$ & $91.69 \%$ & $89.55 \%$ & $100.00 \%$ & $100.00 \%$ & \\
\hline CFA-625 & $79.10 \%$ & $99.73 \%$ & $85.66 \%$ & $82.16 \%$ & $100.00 \%$ & $100.00 \%$ & \\
\hline CITRC & $72.51 \%$ & $100.00 \%$ & $79.70 \%$ & $75.47 \%$ & $100.00 \%$ & $100.00 \%$ & \\
\hline CPP-1774 & $85.22 \%$ & $100.00 \%$ & $90.42 \%$ & $87.60 \%$ & $100.00 \%$ & $100.00 \%$ & $100.00 \%$ \\
\hline CPP-708 & $56.76 \%$ & $90.82 \%$ & $64.31 \%$ & $58.90 \%$ & $95.82 \%$ & $100.00 \%$ & \\
\hline MFC-764 & $84.88 \%$ & $100.00 \%$ & $92.67 \%$ & $88.10 \%$ & $100.00 \%$ & $100.00 \%$ & \\
\hline MFC-774 & $38.63 \%$ & $98.56 \%$ & $49.33 \%$ & $42.65 \%$ & $100.00 \%$ & $100.00 \%$ & \\
\hline NRF & $93.54 \%$ & $100.00 \%$ & $96.23 \%$ & $95.04 \%$ & $100.00 \%$ & $100.00 \%$ & \\
\hline RWMC & $74.74 \%$ & $95.61 \%$ & $79.37 \%$ & $76.92 \%$ & $97.65 \%$ & $100.00 \%$ & $100.00 \%$ \\
\hline TAN-679 & $72.12 \%$ & $100.00 \%$ & $80.35 \%$ & $76.37 \%$ & $100.00 \%$ & $100.00 \%$ & \\
\hline \multirow[t]{2}{*}{ TRA-770 } & $48.67 \%$ & $90.37 \%$ & $55.52 \%$ & $51.23 \%$ & $94.25 \%$ & $100.00 \%$ & $100.00 \%$ \\
\hline & \multicolumn{7}{|c|}{ Network Intensity } \\
\hline Facility & Am-241 & Cs-137 & Pu-238 & Pu-239 & Sr-90 & I-131 & H-3 \\
\hline ATR & $8.27 \%$ & $37.67 \%$ & $10.18 \%$ & $9.02 \%$ & $44.19 \%$ & $91.69 \%$ & \\
\hline CFA-625 & $4.03 \%$ & $15.04 \%$ & $4.58 \%$ & $4.26 \%$ & $20.40 \%$ & $77.16 \%$ & \\
\hline CITRC & $3.32 \%$ & $21.62 \%$ & $4.17 \%$ & $3.60 \%$ & $28.34 \%$ & $81.84 \%$ & \\
\hline CPP-1774 & $5.77 \%$ & $34.42 \%$ & $7.39 \%$ & $6.39 \%$ & $41.07 \%$ & $89.95 \%$ & $99.76 \%$ \\
\hline CPP-708 & $2.24 \%$ & $9.40 \%$ & $2.66 \%$ & $2.34 \%$ & $13.30 \%$ & $70.55 \%$ & \\
\hline MFC-764 & $9.49 \%$ & $46.36 \%$ & $12.68 \%$ & $10.87 \%$ & $52.65 \%$ & $87.02 \%$ & \\
\hline MFC-774 & $2.07 \%$ & $14.38 \%$ & $2.92 \%$ & $2.38 \%$ & $18.01 \%$ & $55.70 \%$ & \\
\hline $\mathrm{NRF}$ & $19.24 \%$ & $55.40 \%$ & $22.94 \%$ & $20.84 \%$ & $62.55 \%$ & $95.76 \%$ & \\
\hline RWMC & $4.12 \%$ & $8.89 \%$ & $4.86 \%$ & $4.39 \%$ & $10.93 \%$ & $60.88 \%$ & $99.84 \%$ \\
\hline TAN-679 & $13.31 \%$ & $43.42 \%$ & $16.24 \%$ & $14.42 \%$ & $50.08 \%$ & $88.04 \%$ & \\
\hline TRA-770 & $1.85 \%$ & $7.96 \%$ & $2.22 \%$ & $1.98 \%$ & $11.04 \%$ & $67.57 \%$ & $99.66 \%$ \\
\hline
\end{tabular}


The FD analysis for Objective B assumed samplers surrounded each facility. Samplers were placed in a circle having a radius equal to the minimum distance to the nearest grazing allotment and centered on the facility (see Table 6). Sixteen samplers spaced 22.5 degrees apart were situated along the circle. Release quantities were determined that corresponded to a maximum 24-hour dose of 1 mrem at one of the samplers as described in Section 4.5. The FD was then calculated for each sampler and the entire 16-sampler network. Individual sampler FDs are useful for identifying optimal sampler placement.

Results of this calculation are shown in Table 15. In this ideal situation, the FD is greater than 95\% for all radionuclides and facilities. Individual sampler FD plots for Am-241 that released from the TRA770 stack, RWMC, the MFC-764 stack, and the TAN-679 facility are shown in Figure 7. The TRA-770 plot is characteristic of releases at INTEC, CFA, and CITRC. These plots illustrate that the relative FD varies with azimuth angle from a given facility and the magnitude is higher for ground-level releases compared to stack releases. In general, FD values were highest for samplers placed northeast and southsouthwest of the facility.

Table 15. Objective B network FD and intensity for the 16 hypothetical samplers surrounding the facility at a distance equal to the nearest grazing allotment boundary.

\begin{tabular}{|l|c|c|c|c|c|c|c|}
\hline \multicolumn{1}{|c|}{ Facility } & Am-241 & Cs-137 & Pu-238 & Pu-239 & Sr-90 & I-131 & H-3 \\
\hline ATR & $100 \%$ & $100 \%$ & $100 \%$ & $100 \%$ & $100 \%$ & $100 \%$ & \\
\hline CFA-625 & $100 \%$ & $100 \%$ & $100 \%$ & $100 \%$ & $100 \%$ & $100 \%$ & \\
\hline CITRC & $100 \%$ & $100 \%$ & $100 \%$ & $100 \%$ & $100 \%$ & $100 \%$ & \\
\hline CPP-1774 & $100 \%$ & $100 \%$ & $100 \%$ & $100 \%$ & $100 \%$ & $100 \%$ & $100 \%$ \\
\hline CPP-708 & $97.7 \%$ & $98.1 \%$ & $97.7 \%$ & $97.7 \%$ & $98.1 \%$ & $98.3 \%$ & \\
\hline MFC-764 & $97.0 \%$ & $98.0 \%$ & $97.1 \%$ & $97.0 \%$ & $98.0 \%$ & $98.0 \%$ & \\
\hline MFC-774 & $100 \%$ & $100 \%$ & $100 \%$ & $100 \%$ & $100 \%$ & $100 \%$ & \\
\hline NRF & $100 \%$ & $100 \%$ & $100 \%$ & $100 \%$ & $100 \%$ & $100 \%$ & \\
\hline RWMC & $100 \%$ & $100 \%$ & $100 \%$ & $100 \%$ & $100 \%$ & $100 \%$ & $100 \%$ \\
\hline TAN-679 & $100 \%$ & $100 \%$ & $100 \%$ & $100 \%$ & $100 \%$ & $100 \%$ & \\
\hline TRA-770 & $97.4 \%$ & $98.2 \%$ & $97.7 \%$ & $97.4 \%$ & $98.1 \%$ & $98.5 \%$ & $98.5 \%$ \\
\hline & & & \multicolumn{7}{|c|}{ Network Intensity } & & \\
\hline Facility & Am-241 & Cs-137 & Pu-238 & Pu-239 & Sr-90 & I-131 & H-3 \\
\hline ATR & $51.1 \%$ & $62.1 \%$ & $52.0 \%$ & $51.4 \%$ & $61.4 \%$ & $63.2 \%$ & \\
\hline CFA-625 & $56.2 \%$ & $65.7 \%$ & $56.9 \%$ & $56.4 \%$ & $64.9 \%$ & $66.4 \%$ & \\
\hline CITRC & $51.5 \%$ & $62.4 \%$ & $52.4 \%$ & $51.9 \%$ & $61.7 \%$ & $63.5 \%$ & \\
\hline CPP-1774 & $49.9 \%$ & $61.2 \%$ & $50.6 \%$ & $50.1 \%$ & $60.3 \%$ & $62.1 \%$ & $62.7 \%$ \\
\hline CPP-708 & $39.3 \%$ & $47.7 \%$ & $40.0 \%$ & $39.5 \%$ & $47.1 \%$ & $48.5 \%$ & \\
\hline MFC-764 & $38.1 \%$ & $47.1 \%$ & $38.7 \%$ & $38.4 \%$ & $46.3 \%$ & $47.8 \%$ & \\
\hline MFC-774 & $50.7 \%$ & $62.1 \%$ & $51.4 \%$ & $51.1 \%$ & $61.3 \%$ & $63.1 \%$ & \\
\hline NRF & $54.9 \%$ & $65.7 \%$ & $55.7 \%$ & $55.3 \%$ & $64.6 \%$ & $66.9 \%$ & \\
\hline RWMC & $54.8 \%$ & $64.0 \%$ & $55.4 \%$ & $55.0 \%$ & $63.5 \%$ & $64.6 \%$ & $64.9 \%$ \\
\hline TAN-679 & $54.1 \%$ & $68.7 \%$ & $55.4 \%$ & $54.7 \%$ & $67.7 \%$ & $69.9 \%$ & \\
\hline TRA-770 & $40.2 \%$ & $48.0 \%$ & $40.6 \%$ & $40.4 \%$ & $47.4 \%$ & $48.9 \%$ & $49.3 \%$ \\
\hline
\end{tabular}



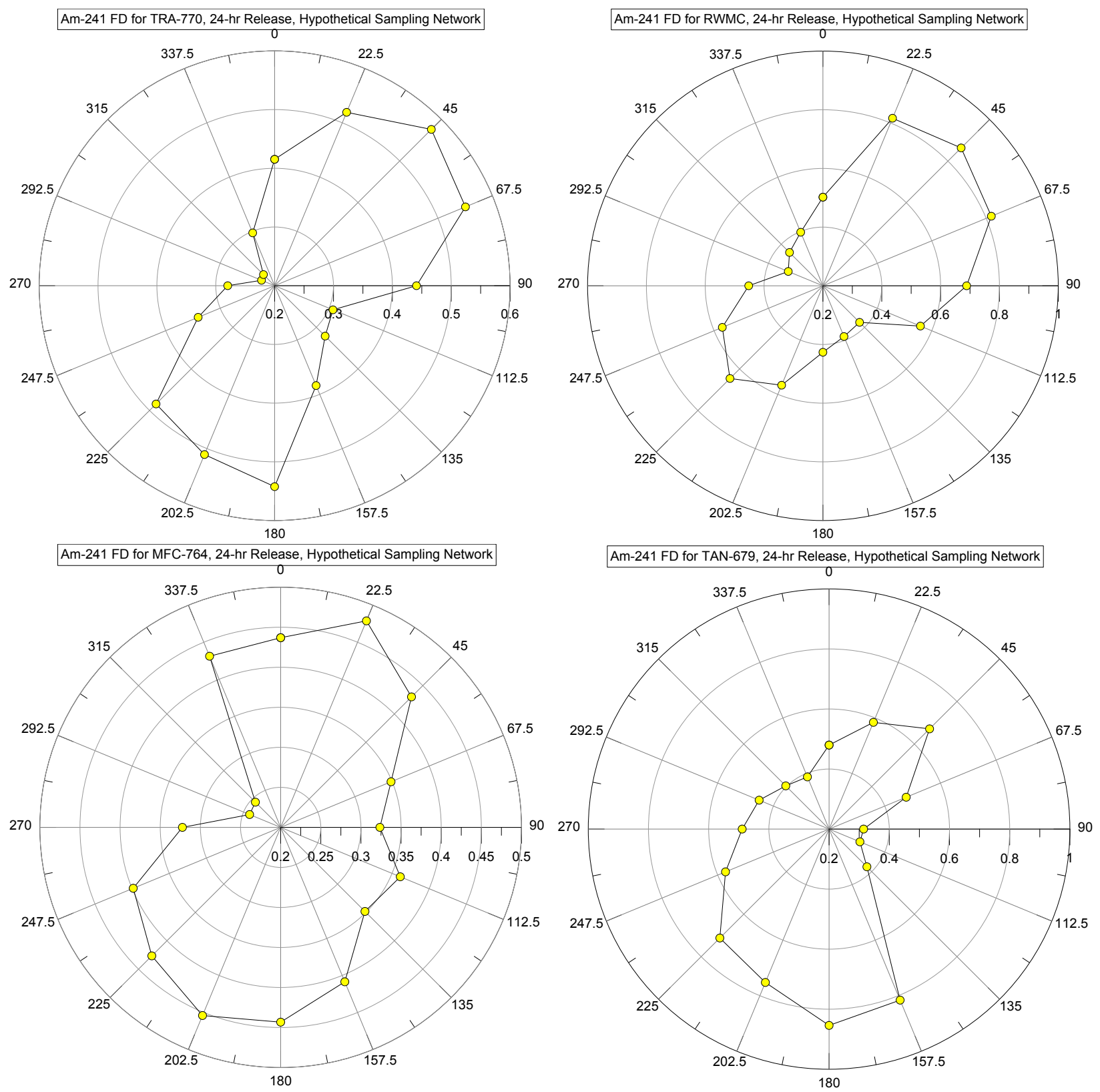

Figure 7. FD of a hypothetical network containing 16-samplers encircling the facility. Plots are for 24-hour Am-241 releases from the TRA-770 stack, RWMC ground level, MFC-764 stack, and TAN-679 ground level.

\subsection{Decision \#6}

\section{Question \#6: Does the existing air monitoring program/network meet the requirements established by resolution of PSQ\#5?}

Action \#6: Use the atmospheric transport model coupled with FD methods to evaluate whether the existing INL Site monitoring network meets the stated performance objectives.

Using the same release quantities for the resident receptor scenario (Objective A), the existing sampler network was evaluated (Table 16). The existing sampler network achieves the 
performance objectives for all radionuclides and facilities (i.e., the current sampling network has a FD of greater than $95 \%$ for a weekly release of a key radionuclide from an INL Site facility that has the potential to result in dose of 0.0192 mrem to a person at a resident receptor location). Network intensities generally ranged from 30 to $80 \%$, depending on the radionuclide, except for sources at MFC, where intensities were overall considerably lower. These results indicate that the current monitoring network can achieve the performance objectives for Objective A. However, overall performance of the sampling network can be improved by optimum sampler placement, which is discussed in Section 8.1.

Table 16. Network FD and intensity for Objective A and the existing sampling network consisting of 36 samplers located on and off the INL Site.

\begin{tabular}{|l|c|c|c|c|c|c|c|}
\hline \multicolumn{1}{|c|}{ Facility } & Am-241 & Cs-137 & Pu-238 & Pu-239 & Sr-90 & I-131 & H-3 \\
\hline ATR & $100 \%$ & $100 \%$ & $100 \%$ & $100 \%$ & $100 \%$ & $100 \%$ & \\
\hline CFA-625 & $100 \%$ & $100 \%$ & $100 \%$ & $100 \%$ & $100 \%$ & $100 \%$ & \\
\hline CITRC & $100 \%$ & $100 \%$ & $100 \%$ & $100 \%$ & $100 \%$ & $100 \%$ & \\
\hline CPP-1774 & $100 \%$ & $100 \%$ & $100 \%$ & $100 \%$ & $100 \%$ & $100 \%$ & $100 \%$ \\
\hline CPP-708 & $100 \%$ & $100 \%$ & $100 \%$ & $100 \%$ & $100 \%$ & $100 \%$ & \\
\hline MFC-764 & $100 \%$ & $100 \%$ & $100 \%$ & $100 \%$ & $100 \%$ & $100 \%$ & \\
\hline MFC-774 & $100 \%$ & $100 \%$ & $100 \%$ & $100 \%$ & $100 \%$ & $100 \%$ & \\
\hline NRF & $100 \%$ & $100 \%$ & $100 \%$ & $100 \%$ & $100 \%$ & $100 \%$ & \\
\hline RWMC & $100 \%$ & $100 \%$ & $100 \%$ & $100 \%$ & $100 \%$ & $100 \%$ & $100 \%$ \\
\hline TAN-679 & $100 \%$ & $100 \%$ & $100 \%$ & $100 \%$ & $100 \%$ & $100 \%$ & \\
\hline TRA-770 & $97.5 \%$ & $100 \%$ & $99.3 \%$ & $98.3 \%$ & $100 \%$ & $100 \%$ & $100 \%$ \\
\hline & & \multicolumn{7}{|c|}{ Network Intensity } & & \\
\hline Facility & Am-241 & Cs-137 & Pu-238 & Pu-239 & Sr-90 & I-131 & H-3 \\
\hline ATR & $44.65 \%$ & $56.04 \%$ & $46.06 \%$ & $45.28 \%$ & $58.34 \%$ & $80.89 \%$ & \\
\hline CFA-625 & $37.98 \%$ & $49.48 \%$ & $40.01 \%$ & $38.77 \%$ & $51.36 \%$ & $70.15 \%$ & \\
\hline CITRC & $28.01 \%$ & $49.60 \%$ & $31.03 \%$ & $29.21 \%$ & $52.11 \%$ & $71.82 \%$ & \\
\hline CPP-1774 & $44.64 \%$ & $55.54 \%$ & $45.98 \%$ & $45.19 \%$ & $57.59 \%$ & $78.71 \%$ & $85.50 \%$ \\
\hline CPP-708 & $11.26 \%$ & $31.70 \%$ & $13.38 \%$ & $12.13 \%$ & $35.43 \%$ & $70.59 \%$ & \\
\hline MFC-764 & $5.05 \%$ & $33.42 \%$ & $6.51 \%$ & $5.56 \%$ & $40.87 \%$ & $82.39 \%$ & \\
\hline MFC-774 & $3.75 \%$ & $10.54 \%$ & $4.22 \%$ & $3.92 \%$ & $12.22 \%$ & $45.88 \%$ & \\
\hline NRF & $49.13 \%$ & $60.50 \%$ & $50.76 \%$ & $49.81 \%$ & $62.67 \%$ & $85.38 \%$ & \\
\hline RWMC & $32.12 \%$ & $45.03 \%$ & $34.63 \%$ & $33.26 \%$ & $46.57 \%$ & $64.25 \%$ & $69.05 \%$ \\
\hline TAN-679 & $8.22 \%$ & $41.11 \%$ & $10.48 \%$ & $9.14 \%$ & $46.74 \%$ & $72.13 \%$ & \\
\hline TRA-770 & $6.19 \%$ & $24.96 \%$ & $7.30 \%$ & $6.67 \%$ & $29.21 \%$ & $66.65 \%$ & $79.24 \%$ \\
\hline
\end{tabular}

FD results for the existing network for the shepherd-rancher scenario (Objective B) are presented in Table 17. The FD was greater than $95 \%$ for all radionuclides and sources, except the actinide releases from MFC-764 stack (FD values ranged from 92 to 94\%). For most of the facilities, samplers are in plume paths that travel northeast and south-southwest from each facility. This is not true for MFC and RWMC, where there are gaps in the sampler network in the principle plume path. These two sources showed the poorest performance in terms of FD. This analysis shows that the performance objectives were achieved for all facilities except MFC. Rearrangement of existing samplers discussed in a later section will address this deficiency in the current network. 
Table 17. Network FD and intensity for Objective B and the existing INL Site sampling network.

\begin{tabular}{|c|c|c|c|c|c|c|c|}
\hline \multirow[b]{2}{*}{ Facility } & \multicolumn{7}{|c|}{ Network FD } \\
\hline & Am-241 & Cs-137 & Pu-238 & Pu-239 & Sr-90 & I-131 & H-3 \\
\hline ATR & $100 \%$ & $100 \%$ & $100 \%$ & $100 \%$ & $100 \%$ & $100 \%$ & \\
\hline CFA-625 & $99 \%$ & $100 \%$ & $98.8 \%$ & $98.7 \%$ & $99.5 \%$ & $100 \%$ & \\
\hline CITRC & $100 \%$ & $100 \%$ & $100 \%$ & $100 \%$ & $100 \%$ & $100 \%$ & \\
\hline CPP-1774 & $100 \%$ & $100 \%$ & $100 \%$ & $100 \%$ & $100 \%$ & $100 \%$ & $100 \%$ \\
\hline CPP-708 & $100 \%$ & $100 \%$ & $100 \%$ & $100 \%$ & $100 \%$ & $100 \%$ & \\
\hline MFC-764 & $92 \%$ & $100 \%$ & $94.2 \%$ & $93.0 \%$ & $100 \%$ & $100 \%$ & \\
\hline MFC-774 & $99 \%$ & $100 \%$ & $99.4 \%$ & $99.3 \%$ & $100 \%$ & $100 \%$ & \\
\hline $\mathrm{NRF}$ & $100 \%$ & $100 \%$ & $100 \%$ & $100 \%$ & $100 \%$ & $100 \%$ & \\
\hline RWMC & $96.9 \%$ & $98.7 \%$ & $96.9 \%$ & $96.9 \%$ & $98.6 \%$ & $99.1 \%$ & $98.7 \%$ \\
\hline TAN-679 & $100 \%$ & $100 \%$ & $100 \%$ & $100 \%$ & $100 \%$ & $100 \%$ & \\
\hline \multirow[t]{2}{*}{ TRA-770 } & $100 \%$ & $100 \%$ & $100 \%$ & $100 \%$ & $100 \%$ & $100 \%$ & $97.8 \%$ \\
\hline & \multicolumn{7}{|c|}{ Network Intensity } \\
\hline Facility & Am-241 & Cs-137 & Pu-238 & Pu-239 & Sr-90 & I-131 & H-3 \\
\hline ATR & $44.4 \%$ & $79.9 \%$ & $45.7 \%$ & $44.9 \%$ & $77.5 \%$ & $82.3 \%$ & \\
\hline CFA-625 & $32.2 \%$ & $75.9 \%$ & $33.5 \%$ & $32.8 \%$ & $71.7 \%$ & $79.6 \%$ & \\
\hline CITRC & $37.7 \%$ & $76.8 \%$ & $39.4 \%$ & $38.4 \%$ & $74.0 \%$ & $79.2 \%$ & \\
\hline CPP-1774 & $46.6 \%$ & $80.3 \%$ & $48.0 \%$ & $47.2 \%$ & $77.9 \%$ & $82.6 \%$ & $78.4 \%$ \\
\hline CPP-708 & $38.7 \%$ & $74.3 \%$ & $40.8 \%$ & $39.5 \%$ & $72.0 \%$ & $76.4 \%$ & \\
\hline MFC-764 & $10.3 \%$ & $62.6 \%$ & $12.0 \%$ & $10.9 \%$ & $58.9 \%$ & $66.1 \%$ & \\
\hline MFC-774 & $16.9 \%$ & $69.2 \%$ & $18.7 \%$ & $17.6 \%$ & $65.3 \%$ & $72.7 \%$ & \\
\hline $\mathrm{NRF}$ & $42.5 \%$ & $78.3 \%$ & $43.8 \%$ & $43.0 \%$ & $75.8 \%$ & $80.8 \%$ & \\
\hline RWMC & $31.6 \%$ & $76.3 \%$ & $32.9 \%$ & $32.2 \%$ & $71.3 \%$ & $80.8 \%$ & $75.0 \%$ \\
\hline TAN-679 & $25.5 \%$ & $71.3 \%$ & $27.4 \%$ & $26.3 \%$ & $67.1 \%$ & $74.8 \%$ & \\
\hline TRA-770 & $35.2 \%$ & $74.7 \%$ & $37.5 \%$ & $36.2 \%$ & $72.3 \%$ & $76.9 \%$ & $73.2 \%$ \\
\hline
\end{tabular}

\section{DECISION ERROR ASSESSMENT}

Chapter 7 of the DQO report discusses the possibility that a wrong decision has been made in Chapter 6 and the possible consequences.

\subsection{Decision \#1 Error}

Radionuclides that are important in terms of radiological dose are based on the 2007 to 2013

NESHAPs reports and are listed in Table 4. These radionuclides have been long established at INL and tie directly to the NESHAP evaluations and to the facility emergency hazard assessments. The potential for an incorrect list is low; however, changing programs or operations could result in identification of new radionuclides and changes in requested laboratory analyses. The important radionuclides identified from NESHAP evaluations included pure beta emitters (i.e., Sr-90 and H-3), beta-gamma emitters (i.e., Cs-137 and I-131), and alpha emitters (i.e., Am-241, Pu-238, and Pu-239). Laboratory detection limits are generally the same for other radionuclides that fall into these three categories. A re-assessment would be needed if a radionuclide were emitted that had a much higher dose consequence per unit activity released compared to the current list of important radionuclides. 


\subsection{Decision \#2 Error}

Major emission sources at INL were identified in Section 4.1. The major facilities that emit radionuclides to the atmosphere were identified and, in some cases, individual stacks or release points were identified and modeled. If an error were made in identifying the major emission sources listed in Section 4.1, then air dispersion modeling and FD methods would have to be applied to the missing sources.

\subsection{Decision \#3 Error}

If the radionuclide release quantities that result in meeting a given dose constraint are underestimated, then the ability of the network to detect releases will also be underestimated and the actual performance of the network (in terms of FD) would be greater than estimated. If the radionuclide release quantities that result in meeting a given dose constraint were overestimated, then FD will also have been overestimated and network (in terms of FD) will have been overestimated. If unanticipated releases occur over a shorter period of time (e.g., 1 hour, 8 hours, etc.), then FD may be less than the target value of $95 \%$, depending on the quantity released.

\subsection{Decision \#4 Error}

The 27 resident receptor locations were based on evaluations of the 98 potential residences around INL. Each of these potential resident receptors was evaluated with air dispersion modeling and FD methodology using 1-year of meteorological data. The results showed a high FD in the existing ambient air surveillance network. Errors in the choice of resident receptor location could mean that the modeling results either over or underestimate release quantities that result in dose constraints being met. This, in turn, would affect the FD results by either overestimating or underestimating the FD.

\subsection{Decision \#5 Error}

Regulatory requirements for an air monitoring program for radionuclides are documented in the DOE Handbook (DOE 2015).) This guidance establishes the analytical and quality assurance requirements that INL must apply to the air monitoring network. A review of the guidance shows that existing network samplers meet the regulatory guidelines. The guidelines allow for some variability in the number and locations of monitors. The adequacy of the number and location of samplers was evaluated for a hypothetical sampler network using FD methods. An error in this evaluation would result in an incorrect assessment of the hypothetical network and, perhaps, an inaccurate estimate of release quantities that result in $10 \%$ of the dose limit being met. Inaccurate estimates of release quantities would affect the FD results.

\subsection{Decision \#6 Error}

The performance metrics of an adequate air monitoring network was quantified in terms of FD. Factors that affect FD include sampler flow rates, radionuclide detection limits, and the number of and placement of samplers. Adequacy of air monitoring equipment was evaluated in Question \#5. Using the release quantities determined in Question \#5, INL sampling was evaluated and found to meet the FD. An error in this assessment was the possibility of some short-term releases going undetected. However, it is unlikely that releases of any dose significance that persist for a week or more for two hypotheticals would go undetected in the current air monitoring network.

\section{NETWORK OPTIMIZATION}

An atmospheric dispersion model, coupled with FD methodology, was used to evaluate the existing INL Site monitoring network to determine if it meets the stated performance objectives. The model and the methodology show that the existing sampler network achieves the performance objectives for all radionuclides and facilities for the resident scenario, but falls short of meeting the performance objectives 
(i.e., 95\% detection frequency) for actinides released from MFC. Poor sampler coverage around the facility was identified as the cause for not meeting the performance objectives. The potential error associated with this decision is that the sampler network may not, in truth, meet the criteria for an "acceptable" air monitoring program. In this scenario, the network would be modified to meet the criteria. Revisions to the air monitoring program could include modifying collection parameters or sampler locations. For this decision, errors would result from problems with various parameter or exposure scenario estimates or with the methodology itself. In this section, sampling network optimization is discussed. Because, for the most part, the existing INL network meets or exceeds performance objectives (i.e., except for sources at MFC), modifications to the existing network are focused on improving the network around MFC and optimizing the network overall.

\subsection{Sampling Locations}

Based on the FD analysis reported in Section 6, several recommendations have been made concerning placement of samplers that will result in overall better system performance. The FD plots provided in Figure 7 provide a general guide to where samplers should be placed relative to a facility to improve detection frequency. In general, samplers should be placed northeast and south-southwest of the release points, although there is some leeway in the actual sampler placement as illustrated in Figure 7. For example, consider the FD values for the TRA-770 stack. Samplers placed at 22.5 and 67.5 degrees have only slightly less detection frequency than the sampler placed at 45 degrees. The current sampling network has samplers placed in these directions for sources at ATR and INTEC. Samplers are also placed in the major direction of plume transport for TAN and NRF. However, two major facilities are lacking samplers in the major direction of plume transport (i.e., RWMC and MFC). Releases from RWMC that travel northwest from the facility will impact the dense sampler network at CFA, INTEC, and TRA. However, no samplers are present for plumes that travel southwest from RWMC. For MFC, a sampler is situated northeast of the facility at Terreton. However, this sampler is distant and dilution and dispersion will reduce air concentrations below the sampler detection limit. The sampler at Atomic City (ESERATO) is well placed and has the highest detection frequency apart from the sampler at MFC. However, an additional sampler placed closer to the facility in a south-southwest direction would improve detection frequency. Overall observations and recommendations are as follows:

- The BEA-ARA sampler is not a very effective location. For example, removing it from the network for a 24-hour release from CITRC would result in an inconsequential reduction of the FD (the FD for Am-241 is reduced to $99.44 \%$ from $99.58 \%$ ). It would be better to move it south-southwest of MFC, if possible, to improve detection of releases from MFC.

- Adding a sampler south-southwest and northeast of MFC would achieve the performance objective of 95\% FD for actinides. Placing a sampler at Location 5 (i.e., south-southwest of MFC) and Location 11 (northeast of MFC) would result in FD values of over 95\% for all actinides for a 24-hour release.

- The sampler FAA-ESER could also be removed or moved to south-southwest of MFC. Removing the sampler from the network does no appreciable change to the detection frequencies for an 8 or 24 -hour release.

- Adding a sampler southwest of RWMC would improve overall detection frequencies. It was shown for a 24-hour release from RWMC that a 95\% detection frequency could be achieved with two samplers placed northeast and southwest of the RWMC.

- Removing samplers BEA-PBF, BEA-ARA, ESER-FAI, and ESER-MAI would not result in detection frequency values for the CPP-708 stack or releases from CITRC from dropping below $95 \%$ for all radionuclides considered.

A contour plot of the annual average dispersion factor for MRF-764 stack (Figure 8) shows that Locations 11 and 5 lie within the major path of a hypothetical plume from the stack; therefore, detection 
frequency would improve if samplers are placed near these locations. Also note that the ESER-FAA and BEA-ARA samplers are outside the contours. A plot of the detection frequency versus azimuth location for all existing samplers and potential resident receptors (Figure 9) shows that adding samplers southsouthwest and northeast of the MFC facility would enhance detection frequency. The rather large detection frequency at 100 degrees is from the onsite MFC sampler. Also note that many of the samplers west of MFC add little or nothing to the overall FD.

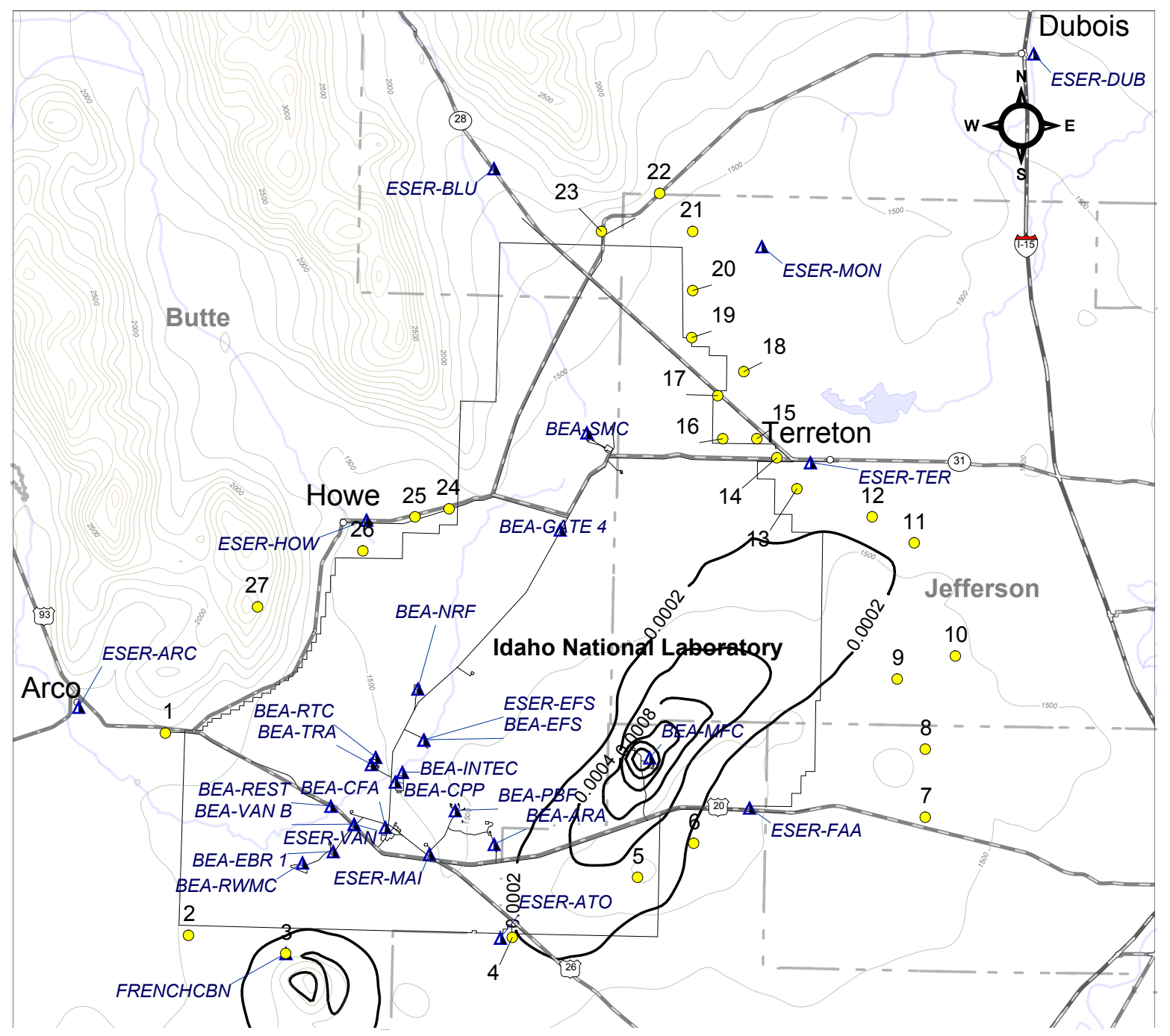

Figure 8. Contour plot of the annual average dispersion factor (or $\mathrm{X} / \mathrm{Q}$ in $\mathrm{s} / \mathrm{m}^{3}$ ) for a steady-state release from MFC-764 stack. 


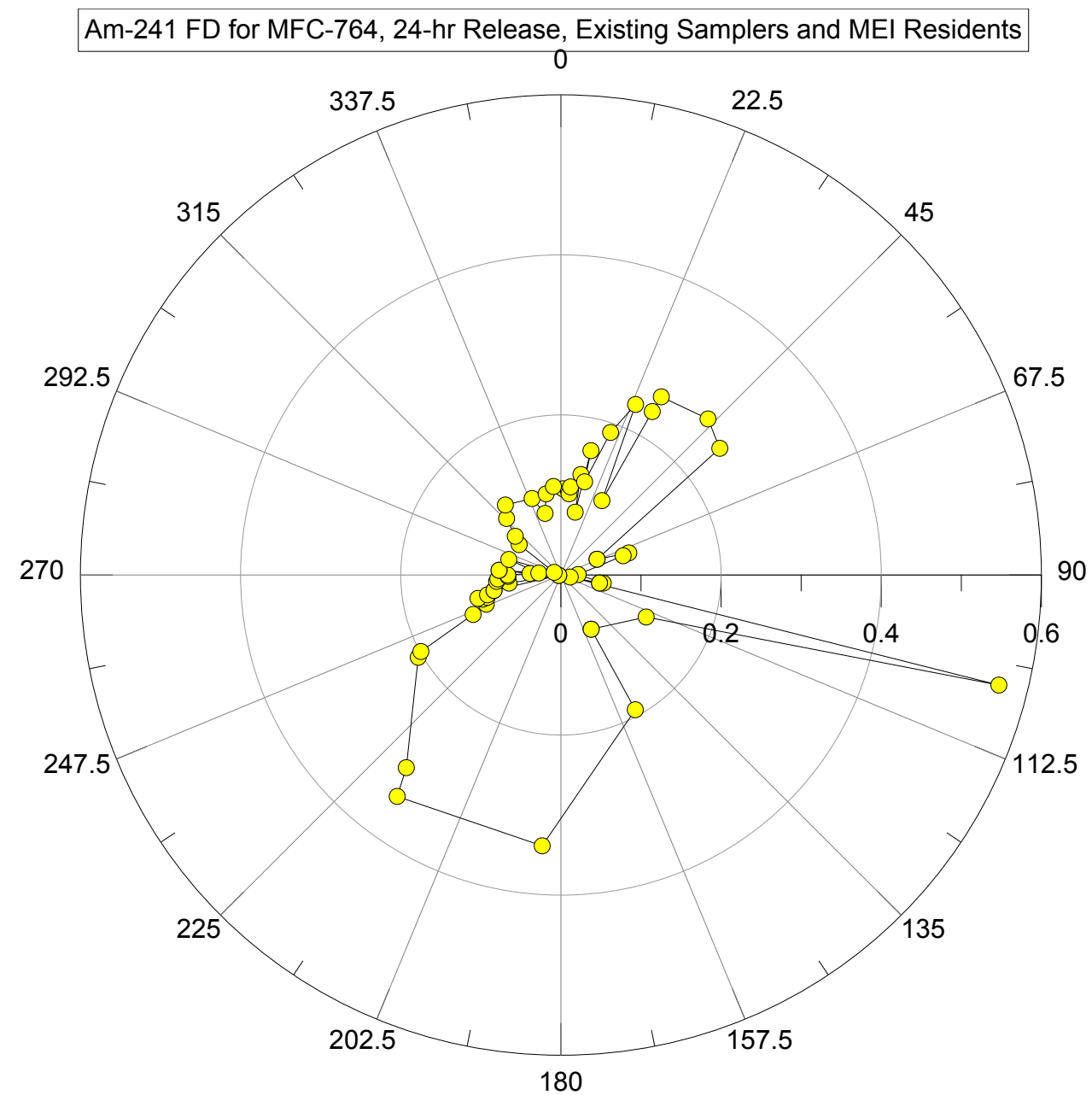

Figure 9. FD versus azimuth for Am-241 released from the MFC-764 stack over a 24-hour period. The rather large detection frequency at azimuth 100 degrees is from the onsite MFC sampler.

To test the proposed changes in the network, sampler locations where power was accessible were identified at locations north and south of MFC and south of RWMC. These sampler locations were simulated with the FD software for the 24-hour release scenario. Additionally, samplers were removed from the network at BEA-PBF, BEA-ARA, ESER-FAA, and ESEF-MAI because these samplers were shown not to change the overall FD for release from the CPP-708 stack. The results of the optimization runs are presented in Table 18. Tritium is not reported because no changes to the tritium monitoring network are proposed. Table 19 presents the percent change in FD and intensity from the optimized network to the existing network. Percent change was calculated using

$\% C=\frac{X_{o}-X_{e}}{X_{o}}$

where $X_{o}=$ the optimized FD or intensity, $X_{e}=$ the existing FD of intensity. A negative percent change indicates the performance measure (i.e., FD or intensity) for the optimized network decreased from the existing network. A positive percent change indicates the performance measure for the optimized network increased from the existing network.

Removing the four samplers previously mentioned results in a small decrease in FD (less than 1.5\%) for sources at CFA, CITRC, and TAN, and decreases in network intensity for sources at ATR, CITRC, 
CFA, RWMC, and TAN. However, all sources meet the performance criteria of $95 \%$ FD. Adding samplers at MFC and RWMC improve FD by up to $6.95 \%$ for the MFC-764 stack source and 3.08\% for the RWMC sources. If samplers at ESER-FAA and BEA-ARA are only removed, then there is no appreciable change in network FD and intensity.

Table 18. Network FD and intensity for Objective B and the optimized INL Site sampling network.

\begin{tabular}{|c|c|c|c|c|c|c|}
\hline \multirow[b]{2}{*}{ Facility } & \multicolumn{6}{|c|}{ Optimized Network Frequency of Detection } \\
\hline & Am-241 & Cs-137 & Pu-238 & Pu-239 & Sr-90 & I-131 \\
\hline ATR & $100.0 \%$ & $100.0 \%$ & $100.0 \%$ & $100.0 \%$ & $100.0 \%$ & $100.0 \%$ \\
\hline CFA-625 & $98.0 \%$ & $99.9 \%$ & $98.6 \%$ & $98.3 \%$ & $99.9 \%$ & $99.9 \%$ \\
\hline CITRC & $98.3 \%$ & $99.8 \%$ & $98.4 \%$ & $98.3 \%$ & $99.8 \%$ & $99.8 \%$ \\
\hline CPP-1774 & $100.0 \%$ & $100.0 \%$ & $100.0 \%$ & $100.0 \%$ & $100.0 \%$ & $100.0 \%$ \\
\hline CPP-708 & $100.0 \%$ & $100.0 \%$ & $100.0 \%$ & $100.0 \%$ & $100.0 \%$ & $100.0 \%$ \\
\hline MFC-764 & $98.7 \%$ & $100.0 \%$ & $99.0 \%$ & $98.9 \%$ & $100.0 \%$ & $100.0 \%$ \\
\hline MFC-774 & $100.0 \%$ & $100.0 \%$ & $100.0 \%$ & $100.0 \%$ & $100.0 \%$ & $100.0 \%$ \\
\hline $\mathrm{NRF}$ & $99.8 \%$ & $100.0 \%$ & $99.8 \%$ & $99.8 \%$ & $100.0 \%$ & $100.0 \%$ \\
\hline RWMC & $100.0 \%$ & $100.0 \%$ & $100.0 \%$ & $100.0 \%$ & $100.0 \%$ & $100.0 \%$ \\
\hline TAN-679 & $99.3 \%$ & $100.0 \%$ & $99.5 \%$ & $99.4 \%$ & $100.0 \%$ & $100.0 \%$ \\
\hline \multirow[t]{2}{*}{ TRA-770 } & $99.8 \%$ & $100.0 \%$ & $99.8 \%$ & $99.8 \%$ & $100.0 \%$ & $100.0 \%$ \\
\hline & \multicolumn{6}{|c|}{ Optimized Network Intensity } \\
\hline Facility & Am-241 & Cs-137 & Pu-238 & Pu-239 & Sr-90 & I-131 \\
\hline ATR & $43.8 \%$ & $77.9 \%$ & $45.2 \%$ & $44.4 \%$ & $77.2 \%$ & $82.2 \%$ \\
\hline CFA-625 & $30.2 \%$ & $72.2 \%$ & $31.6 \%$ & $30.8 \%$ & $71.0 \%$ & $79.1 \%$ \\
\hline CITRC & $35.5 \%$ & $76.4 \%$ & $37.2 \%$ & $36.2 \%$ & $73.6 \%$ & $79.0 \%$ \\
\hline СРP-1774 & $45.7 \%$ & $78.3 \%$ & $47.1 \%$ & $46.3 \%$ & $77.7 \%$ & $82.4 \%$ \\
\hline СРP-708 & $39.3 \%$ & $74.4 \%$ & $41.3 \%$ & $40.1 \%$ & $72.0 \%$ & $76.4 \%$ \\
\hline MFC-764 & $13.4 \%$ & $63.0 \%$ & $14.9 \%$ & $14.0 \%$ & $59.2 \%$ & $66.5 \%$ \\
\hline MFC-774 & $17.4 \%$ & $66.7 \%$ & $19.1 \%$ & $18.1 \%$ & $65.6 \%$ & $73.1 \%$ \\
\hline NRF & $42.5 \%$ & $76.6 \%$ & $43.8 \%$ & $43.0 \%$ & $75.8 \%$ & $80.8 \%$ \\
\hline RWMC & $31.3 \%$ & $72.0 \%$ & $32.6 \%$ & $31.9 \%$ & $70.8 \%$ & $80.5 \%$ \\
\hline TAN-679 & $24.9 \%$ & $68.1 \%$ & $26.8 \%$ & $25.7 \%$ & $67.1 \%$ & $74.8 \%$ \\
\hline TRA-770 & $36.2 \%$ & $73.0 \%$ & $38.4 \%$ & $37.2 \%$ & $72.4 \%$ & $77.0 \%$ \\
\hline
\end{tabular}

Individual sampler FD for Am-241 releases from the MFC-764 stack was 78.2\% for the proposed MFC north sampler and 65.5\% for the proposed sampler at the MFC Guard Shack. The existing MFC sampler had a FD of 59.4\%. Moving the existing sampler to the MFC parking lot had no appreciable change on detection frequency. Individual sampler FD for Am-241 releases from RWMC were 79.9\% for the proposed RWMC south sampler and $96.8 \%$ for the existing RWMC sampler.

Table 19. Percent change in network FD and intensity from the optimized and existing network.

\begin{tabular}{|l|c|c|c|c|c|c|}
\hline & \multicolumn{6}{|c|}{ Percent Change for Frequency of Detection } \\
\hline \multicolumn{1}{|c|}{ Facility } & Am-241 & Cs-137 & Pu-238 & Pu-239 & Sr-90 & I-131 \\
\hline ATR & $0.00 \%$ & $0.00 \%$ & $0.00 \%$ & $0.00 \%$ & $0.00 \%$ & $0.00 \%$ \\
\hline CFA-625 & $-0.66 \%$ & $0.39 \%$ & $-0.20 \%$ & $-0.36 \%$ & $0.39 \%$ & $0.36 \%$ \\
\hline CITRC & $-1.34 \%$ & $-0.16 \%$ & $-1.30 \%$ & $-1.30 \%$ & $-0.16 \%$ & $-0.16 \%$ \\
\hline CPP-1774 & $0.00 \%$ & $0.00 \%$ & $0.00 \%$ & $0.00 \%$ & $0.00 \%$ & $0.00 \%$ \\
\hline
\end{tabular}




\begin{tabular}{|l|c|c|c|c|c|c|}
\hline & \multicolumn{7}{|c|}{ Percent Change for Frequency of Detection } \\
\hline \multicolumn{1}{|c|}{ Facility } & Am-241 & Cs-137 & Pu-238 & Pu-239 & Sr-90 & I-131 \\
\hline CPP-708 & $0.00 \%$ & $0.00 \%$ & $0.00 \%$ & $0.00 \%$ & $0.00 \%$ & $0.00 \%$ \\
\hline MFC-764 & $6.95 \%$ & $0.10 \%$ & $4.79 \%$ & $5.97 \%$ & $0.10 \%$ & $0.07 \%$ \\
\hline MFC-774 & $0.74 \%$ & $0.10 \%$ & $0.61 \%$ & $0.70 \%$ & $0.01 \%$ & $0.01 \%$ \\
\hline NRF & $0.00 \%$ & $0.00 \%$ & $0.00 \%$ & $0.00 \%$ & $0.00 \%$ & $0.00 \%$ \\
\hline RWMC & $3.08 \%$ & $1.40 \%$ & $3.08 \%$ & $3.08 \%$ & $1.37 \%$ & $0.93 \%$ \\
\hline TAN-679 & $-0.34 \%$ & $0.00 \%$ & $-0.37 \%$ & $-0.44 \%$ & $0.00 \%$ & $0.00 \%$ \\
\hline TRA-770 & $0.00 \%$ & $0.00 \%$ & $0.00 \%$ & $0.00 \%$ & $0.00 \%$ & $0.00 \%$ \\
\hline & & & Percent Change for Intensity & \\
\hline Facility & $\mathbf{A m - 2 4 1}$ & $\mathbf{C s - 1 3 7}$ & $\mathbf{P u - 2 3 8}$ & $\mathbf{P u - 2 3 9}$ & $\mathbf{S r - 9 0}$ & $\mathbf{I - 1 3 1}$ \\
\hline ATR & $-1.23 \%$ & $-0.26 \%$ & $-1.22 \%$ & $-1.26 \%$ & $-0.30 \%$ & $-0.09 \%$ \\
\hline CFA-625 & $-6.52 \%$ & $-0.93 \%$ & $-6.11 \%$ & $-6.33 \%$ & $-1.03 \%$ & $-0.61 \%$ \\
\hline CITRC & $-6.32 \%$ & $2.30 \%$ & $-5.72 \%$ & $-6.03 \%$ & $-0.56 \%$ & $-0.34 \%$ \\
\hline CPP-1774 & $-2.03 \%$ & $-0.31 \%$ & $-1.91 \%$ & $-1.94 \%$ & $-0.33 \%$ & $-0.18 \%$ \\
\hline CPP-708 & $1.50 \%$ & $2.49 \%$ & $1.28 \%$ & $1.45 \%$ & $0.11 \%$ & $0.05 \%$ \\
\hline MFC-764 & $23.34 \%$ & $4.96 \%$ & $19.45 \%$ & $21.94 \%$ & $0.57 \%$ & $0.60 \%$ \\
\hline MFC-774 & $2.87 \%$ & $0.45 \%$ & $1.89 \%$ & $2.49 \%$ & $0.44 \%$ & $0.51 \%$ \\
\hline NRF & $0.00 \%$ & $0.00 \%$ & $0.00 \%$ & $0.00 \%$ & $0.00 \%$ & $0.00 \%$ \\
\hline RWMC & $-0.93 \%$ & $-0.65 \%$ & $-1.10 \%$ & $-1.00 \%$ & $-0.69 \%$ & $-0.37 \%$ \\
\hline TAN-679 & $-2.25 \%$ & $-0.07 \%$ & $-2.16 \%$ & $-2.29 \%$ & $-0.06 \%$ & $0.00 \%$ \\
\hline TRA-770 & $2.79 \%$ & $0.16 \%$ & $2.34 \%$ & $2.58 \%$ & $0.17 \%$ & $0.09 \%$ \\
\hline
\end{tabular}

\section{REFERENCES}

10 CFR 100, Subpart A, 2002, "Determination of Exclusion Area, Low Population Zone, and Population Center Distance," Code of Federal Regulations, Office of the Federal Register, November 2002.

40 CFR 61, Subpart H, 2010, "National Emission Standards for Emissions of Radionuclides Other than Radon from Department of Energy Facilities," Code of Federal Regulations, Office of the Federal Register, April 2010.

DOE, 1991, Environmental Regulatory Guide for Radiological Effluent Monitoring and Environmental Surveillance, DOE/EH-0173T, January 1991.

DOE, 2015, DOE Handbook, "Environmental Radiological Effluent Monitoring and Environmental Surveillance," DOE-HDBK-1216-2015.

DOE Order 458.1, 2011, "Radiation Protection of the Public and Environment," U.S. Department of Energy, February 2011.

DOE-ID, 2014a, Technical Basis for Environmental Monitoring and Surveillance at the Idaho National Laboratory Site, DOE/ID-11485, U.S. Department of Energy, Idaho Operations Office, February 2014.

DOE-ID, 2014b, Idaho National Laboratory Site Environmental Report Calendar Year 2013, DOE/ID-12082(13), U.S. Department of Energy, Idaho Operations Office, Environmental Surveillance, Education, and Research Program, Idaho Falls, ID. 
DOE-ID, 2014c, National Emission Standards for Hazardous Air Pollutants - CY 2013 INL Report for Radionuclides, DOE/ID-11441 (2014), U.S. Department of Energy Idaho Operations Office.

DOE-STD-1196-2011, 2011, Derived Concentration Technical Standard, U.S. Department of Energy, April 2011.

EPA, 1993, "External Exposure to Radionuclides in Air, Water and Soil: Federal Guidance Report No. 12,” EPA 402-R-93-081, U.S. Environmental Protection Agency, Washington D.C.

EPA, 2000, "Meteorological Monitoring Guidance for Regulatory Modeling Applications," EPA-454/R99-005, U.S. Environmental Protection Agency Office of Air Quality and Planning and Standards, 2000 .

EPA, 2006, "Guidance on Systematic Planning Using the Data Quality Objectives Process," EPA/240/B-06/001, U.S. Environmental Protection Agency, February 2006.

Rood, A. S. and A. J. Sondrup, 2014, Development and Demonstration of a Methodology to Quantitatively Assess the INL Site Ambient Air Monitoring Network, INL/EXT-14-33194, December 2014.

Turner, D. B., 1994, Workbook of Atmospheric Dispersion Estimates, Second Edition, Lewis Publishers, Boca Raton, Florida, 1994. 


\section{Appendix A}

\section{Gaussian Plume Model}

This appendix contains a description of the Gaussian plume model and its implementation in a Perl script for generation of TICs for use in FD analysis

\section{A-1. GAUSSIAN PLUME FORMULATION}

The Gaussian plume model for a conservative tracer with no deposition or depletion is given by (Turner 1994):

$$
\begin{aligned}
& \chi(x, y, z, u, H, Q)=\frac{Q}{2 \pi u \sigma_{y} \sigma_{z}} \exp \left[-\frac{y^{2}}{2 \sigma_{y}^{2}}\right] G(z) \\
& G(z)=\sum_{n=-\infty}^{\infty}\left\{\exp \left[-\frac{1}{2}\left(\frac{2 n H-z_{h}-z}{\sigma_{z}}\right)^{2}\right]+\exp \left[-\frac{1}{2}\left(\frac{2 n H+z_{h}-z}{\sigma_{z}}\right)^{2}\right]\right\}
\end{aligned}
$$

where

$$
\begin{array}{ll}
x & =\text { downwind distance }(\mathrm{m}) \\
y & =\text { crosswind distance }(\mathrm{m}) \\
z & =\text { height above ground }(\mathrm{m}) \\
u & =\text { wind speed }\left(\mathrm{m} \mathrm{s}^{-1}\right) \\
z_{h} & =\text { plume height }(\text { stack height plus plume rise) }(\mathrm{m}) \\
H & =\text { mixing height }(\mathrm{m}) \\
\sigma_{y}, \sigma_{z} & =\text { diffusion coefficients in the } y \text { and } z \text { direction, respectively } \\
Q & =\text { continuous release rate }\left(\mathrm{Ci} \mathrm{s}^{-1}\right) .
\end{array}
$$

For a release of finite duration, TIC is found by integrating Equation (A-1). Because there are no time terms in Equation (A-1), the TIC is simply $\chi$ times the integration time. Assuming that transport time from source to receptor is short relative to release time, then the TIC is simply Equation (A-1) replacing the release rate $(Q)$ with the quantity released over the integration time $(q$, in $\mathrm{Ci})$.

\section{A-1.1 Release Height}

The release height is the physical height of the release plus plume rise due to momentum or buoyant rise. Both momentum and buoyant rise are calculated and the higher of the two are used in the calculations.

Buoyancy flux $(F)$ is given by Equation 3.3 in Turner (1994):

$$
F=\frac{g v d^{2} \Delta T}{4 T_{s}}
$$


where

$$
\begin{aligned}
& g=\text { acceleration due to gravity }\left(9.8 \mathrm{~m} \mathrm{~s}^{-2}\right), \\
& v=\text { stack-gas exit velocity }\left(\mathrm{m} \mathrm{s}^{-1}\right), \\
& d=\text { inside stack diameter at top of stack }(\mathrm{m}), \\
& \Delta \mathrm{T}=\text { stack gas temperature minus ambient temperature }(\mathrm{K}), \\
& T_{s}=\text { stack gas temperature }(\mathrm{K}) .
\end{aligned}
$$

For unstable or neutral conditions, the buoyant rise is given by

$$
\begin{gathered}
\Delta H=\frac{21.425 F^{3 / 4}}{u_{h}}, \quad F<55 \\
\Delta H=\frac{38.71 F^{3 / 5}}{u_{h}}, \quad F \geq 55
\end{gathered}
$$

where $u_{h}=$ the wind speed at the top of the stack $\left(\mathrm{m} \mathrm{s}^{-1}\right)$.

For unstable or neutral conditions, the momentum rise is given by

$$
\Delta H=\frac{3 d v}{u_{h}}
$$

For stable conditions, the buoyant rise is a function of the stability parameter $(s)$.

$$
\begin{gathered}
s=\frac{g \frac{d \theta}{d z}}{T} \\
\frac{d \theta}{d z}=\frac{d T}{d z}+\Gamma
\end{gathered}
$$

where $\Gamma$ is the adiabatic lapse rate $(0.0098 \mathrm{~K} / \mathrm{m})$. The final buoyant rise is given by two equations where the lower of the two values is used

$$
\begin{aligned}
& \Delta H=2.6\left[\frac{F}{u_{h} s}\right]^{1 / 3} \\
& \Delta H=4 F^{1 / 4} s^{-3 / 8} .
\end{aligned}
$$

Momentum rise in stable conditions is

$$
\Delta H=1.5\left[\frac{v^{2} d^{2} T}{4 T_{s} u_{h}}\right]^{1 / 3} s^{-1 / 6} .
$$

Momentum rise under stable conditions is also calculated using A-4 and the lower of the two values is used. 


\section{A-1.2 Diffusion Coefficients}

The diffusion coefficients used in this assessment were the Briggs Urban coefficients described in Turner (1994). Both the Pasquill-Gifford and Briggs dispersion coefficients were run in the model and compared with results from CALPUFF. The Briggs dispersion coefficients produced doses much closer to those of CALPUFF compared to the PG dispersion coefficients (Table 1). For these reasons, the Briggs dispersion coefficients were used.

Table A-1. Am-241 inhalation dose and TIC for a release of 6.907E+07 pCi from CPP-1774, 1-hour release time.

\begin{tabular}{lrrrrrr}
\hline \multicolumn{1}{c}{ Sampler } & Distance & Bearing & $\begin{array}{c}\text { GP Dose } \\
(\mathrm{mrem})\end{array}$ & $\begin{array}{c}\text { CALPUFF } \\
\text { Dose(mrem) }\end{array}$ & $\begin{array}{c}\text { GP TIC } \\
\left(\mathrm{pCi}-\mathrm{hour} / \mathrm{m}^{3}\right)\end{array}$ & $\begin{array}{r}\text { CALPUFF TIC } \\
(\mathrm{pCi}-\text { hour/m }\end{array}$ \\
\hline Briggs Dispersion Coefficients \\
BEA-TRA & 3,040 & 304 & 0.182 & 0.165 & 0.661 & 0.5993 \\
BEA-CPP & 343 & 290 & 3.945 & 2.511 & 14.3 & 9.124 \\
BEA-INTEC & 1,050 & 18 & 0.736 & 0.5738 & 2.67 & 2.09 \\
BEA-RTC & 3,161 & 318 & 0.1417 & 0.184 & 0.515 & 0.669 \\
Pasquill-Gifford Dispersion Coefficients & & & & \\
BEA-TRA & 3,040 & 304 & 0.409 & 0.165 & 1.49 & 0.5993 \\
BEA-CPP & 343 & 290 & 6.25 & 2.511 & 22.7 & 9.124 \\
BEA-INTEC & 1,050 & 18 & 6.47 & 0.5738 & 23.5 & 2.09 \\
BEA-RTC & 3,161 & 318 & 0.6129 & 184 & 2.23 & 0.669 \\
\hline
\end{tabular}

\section{A-1.3 Stability Class} (2000).

Stability class was determined using the solar radiation-delta-temperature method described in EPA

\section{A-1.4 Coordinate Transformations}

The coordinates of each of the receptors $\left(x_{\text {rec }}, y_{\text {rec }}\right)$ located at distance $r$ and azimuth $\phi$ from the source were calculated as follows:

$$
\begin{aligned}
& x_{\text {rec }}=\sin (\phi) r+x_{\text {source }} \\
& y_{\text {rec }}=\cos (\phi) r+y_{\text {source }}
\end{aligned}
$$

where $x_{\text {source }}$ and $y_{\text {source }}$ are the coordinates of the source. In most cases, the wind does not blow at the same azimuth direction as the receptor is from the source. The downwind distance $x$ and crosswind distance $y$ of the receptor located at azimuth $\phi$ and a wind vector $\psi$ is given by (see Figure A-1)

$$
\begin{aligned}
& x=r-a b s\left(x_{\text {rec }}-x_{\text {wind }}\right) \\
& y=r \sin (\phi-\psi) \\
& x_{\text {wind }}=\sin (\psi) r+x_{\text {source }} .
\end{aligned}
$$




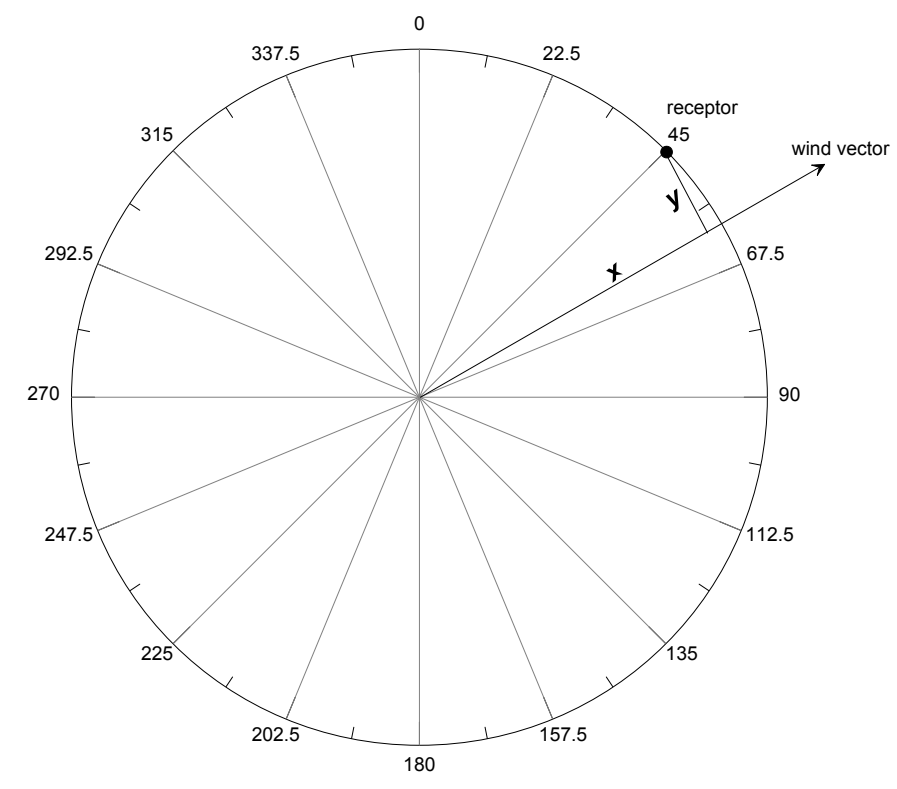

Figure A-1. Diagram showing downwind distance and crosswind distance for a receptor located at azimuth 45 degrees and wind vector azimuth of 58 degrees. 


\section{Appendix B}

\section{Tritium Sampling}

This appendix contains a description of tritium sampling methods and how the MDA and sampler flow rates are determined. Tritium detection is reported in terms of the minimum detectable concentration in atmospheric water. The tritium sampler collects atmospheric water, which involves a 9-mL sample of collected water being taken and analyzed for tritium. Parameters needed for the FD analysis are sampler flow rate, sample time, and MDA. Average flow rates, water collection volumes, sampling time, and MDA are derived from data in Table B-1. Other assumptions and data are as follows:

Data:

Sampler flow rate for atmospheric moisture:

Water collection amount during sampling period:

Sampling time:

Absolute humidity:

Amount of water analyzed:

Collection efficiency of water vapor:

Minimum detectable concentration for tritium in water: $83.9 \mathrm{pCi} / \mathrm{L}$.

Table B-1. Tritium sampler data from Atomic City for sampling during 2014.

\begin{tabular}{cccccccc}
\hline Date On & Date Off & $\begin{array}{c}\text { Water } \\
\text { Collected }(\mathbf{m L})\end{array}$ & $\begin{array}{c}\text { Flow Meter } \\
\text { On }\end{array}$ & $\begin{array}{c}\text { Flow Meter } \\
\text { Off }\end{array}$ & $\begin{array}{c}\text { Air Volume } \\
\left(\mathbf{m}^{\mathbf{3}}\right)\end{array}$ & $\begin{array}{c}\text { Days } \\
\text { Sampled }\end{array}$ & $\begin{array}{c}\text { Flow Rate } \\
\left(\mathbf{m}^{\mathbf{3}} / \mathbf{h r}\right)\end{array}$ \\
\hline $12 / 31 / 13$ & $2 / 12 / 14$ & 52.1 & 672.167 & 691.913 & 19.746 & 43 & 0.01913 \\
$2 / 12 / 14$ & $3 / 12 / 14$ & 56 & 691.913 & 706.214 & 14.301 & 28 & 0.02128 \\
$3 / 12 / 14$ & $4 / 17 / 14$ & 43 & 706.214 & 722.245 & 16.031 & 36 & 0.01855 \\
$4 / 17 / 14$ & $5 / 14 / 14$ & 43.9 & 722.245 & 734.092 & 11.847 & 27 & 0.01828 \\
$5 / 14 / 14$ & $6 / 11 / 14$ & 47.8 & 734.092 & 745.802 & 11.71 & 28 & 0.01743 \\
$6 / 11 / 14$ & $7 / 9 / 14$ & 42.4 & 745.802 & 754.139 & 8.337 & 28 & 0.01241 \\
$7 / 9 / 14$ & $7 / 30 / 14$ & 52.2 & 754.139 & 763.47 & 9.331 & 21 & 0.01851 \\
$7 / 30 / 14$ & $8 / 13 / 14$ & 52.7 & 763.47 & 769.756 & 6.286 & 14 & 0.01871 \\
$8 / 13 / 14$ & $8 / 27 / 14$ & 53.1 & 769.756 & 776.34 & 6.584 & 14 & 0.01960 \\
$8 / 27 / 14$ & $9 / 17 / 14$ & 43.5 & 776.34 & 785.597 & 9.257 & 21 & 0.01837 \\
$9 / 17 / 14$ & $10 / 1 / 14$ & 51.5 & 785.597 & 792.841 & 7.244 & 14 & 0.02156 \\
$10 / 1 / 14$ & $10 / 29 / 14$ & 53.9 & 792.841 & 808.369 & 15.528 & 28 & 0.02311 \\
$10 / 29 / 14$ & $12 / 10 / 14$ & 57.2 & 808.369 & 828.696 & 20.327 & 42 & 0.02017 \\
$12 / 10 / 14$ & $1 / 14 / 15$ & 47.3 & 828.696 & 849.113 & 20.417 & 35 & 0.02431 \\
& Average & 49.75 & & & & 27 & 0.01939 \\
\hline
\end{tabular}

For a 9-mL sample taken for analysis, MDA can be calculated as follows:

$83.6 \mathrm{pCi} / \mathrm{L} \times 1 \mathrm{~L} / 1000 \mathrm{~mL} \times 9 \mathrm{~mL}=0.752 \mathrm{pCi}$.
$0.019 \mathrm{~m}^{3} /$ hour $=19 \mathrm{~L} /$ hour

$50 \mathrm{~mL}(0.05 \mathrm{~L})$

27 days (648 hours)

$0.00345 \mathrm{~g} / \mathrm{L}$

$9 \mathrm{~mL}$

$100 \%$ 